\title{
Theodor Storm's Craft of Fiction
}

The Torment of a Narrator 
Theodor Storm's Craft of Fiction 


\section{IIIIUNC}

From 1949 to 2004, UNC Press and the UNC Department of Germanic \& Slavic Languages and Literatures published the UNC Studies in the Germanic Languages and Literatures series. Monographs, anthologies, and critical editions in the series covered an array of topics including medieval and modern literature, theater, linguistics, philology, onomastics, and the history of ideas. Through the generous support of the National Endowment for the Humanities and the Andrew W. Mellon Foundation, books in the series have been reissued in new paperback and open access digital editions. For a complete list of books visit www.uncpress.org. 



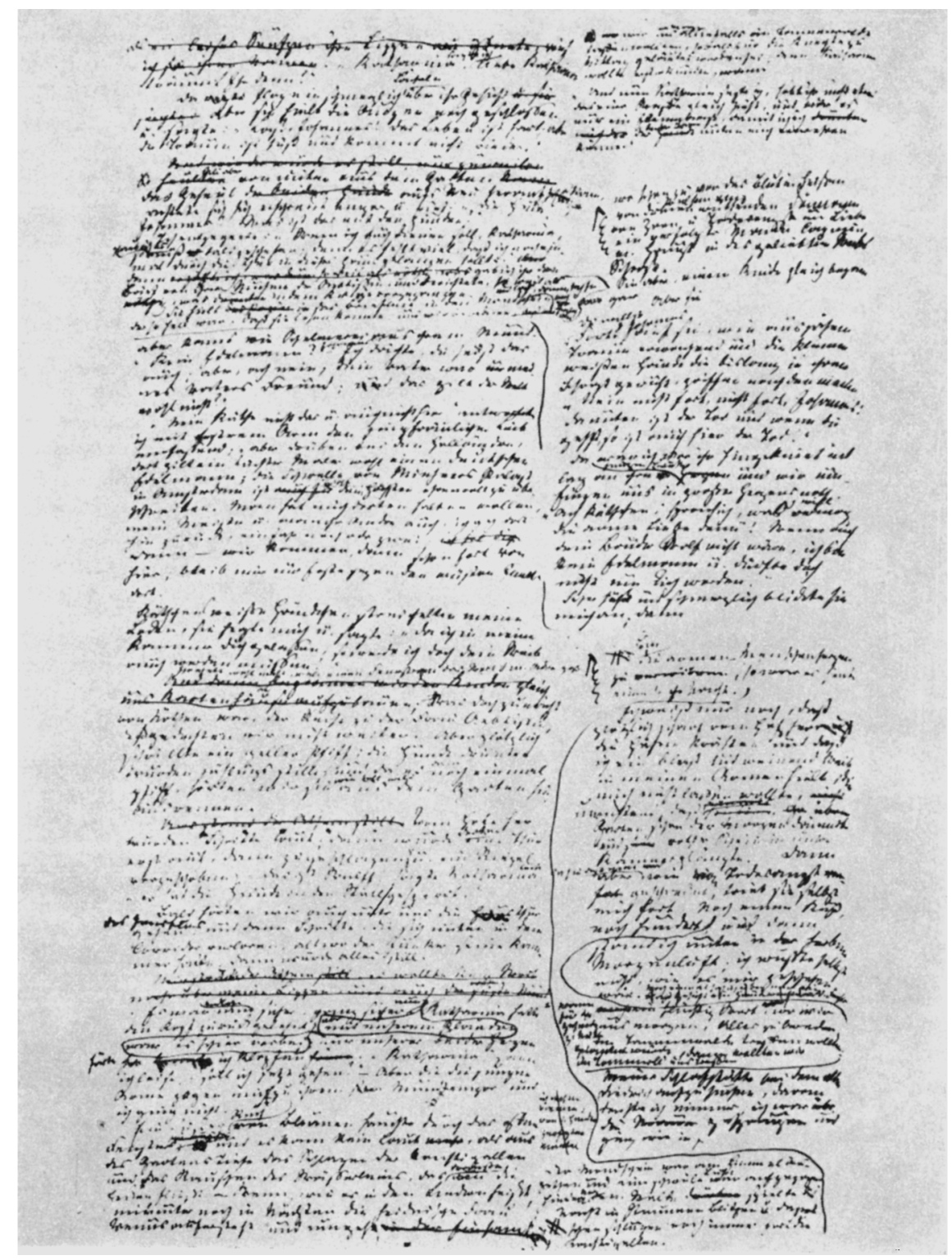

A page from the first draft of Aquis submersus. 


\section{Theodor Storm's Craft of Fiction}

The Torment of a Narrator

Second Edition

CLIFFORD A. BERND

UNC Studies in the Germanic Languages and Literatures Number 55 
Copyright (C) 1966

This work is licensed under a Creative Commons CC BY-NC-ND license. To view a copy of the license, visit http://creativecommons. org/licenses.

Suggested citation: Bernd, Clifford. Theodor Storm's Craft of Fiction: The Torment of a Narrator, Second Edition. Chapel Hill:

University of North Carolina Press, 1966. DOI: https://doi.org/ 10.5149/9781469657080_Bernd

Library of Congress Cataloging-in-Publication Data Names: Bernd, Clifford.

Title: Theodor Storm's craft of fiction : The torment of a narrator, second edition / by Clifford A. Bernd.

Other titles: University of North Carolina Studies in the Germanic Languages and Literatures ; no. 55.

Description: Chapel Hill : University of North Carolina Press, [1966] Series: University of North Carolina Studies in the Germanic Languages and Literatures. | Includes bibliographical references. Identifiers: LCCN 67063060 | ISBN 978-1-4696-5707-3 (pbk: alk. paper) | ISBN 978-1-4696-5708-o (ebook)

Subjects: Storm, Theodor, 1817-1888.

Classification: LCC PD25 .N6 NO. 55 | DCC 833/.8 


for

Paul Böckmann 
Das hohe und innerlich vielerfahrene Künstlertum Storms hat nichts zu schaffen mit Simpelei und Winkeldumptigkeit, nichts mit dem, was man wohl eine Zeitlang 'Heimatkunst' nannte.

Ich betone die sensitive Vergeistigung, den Extremismus seiner Gemütshaftigkeit so sehr und spreche sogar von leichter Krankhaftigkeit, um nichts auf ihn kommen zu lassen, was auf Bürgernormalität oder -sentimentalität, auf seelisches Philistertum hinausliefe...

THOMAS MANN 


\section{PREFACE TO SECOND, AUGMENTED EDITION}

To the delight of the editor of the University of North Carolina Studies in the Germanic Languages and Litcratures, and to the delight as well as surprise of the author, this book's first edition went out of print only two years after its publication in 1963. During this period of time I have received from colleagues and friends a number of letters concerning various points made in the book. Other critics have reviewed it in journals. The reviews that have come to my attention are those by: (1) Ulf Bichel in Nordelbingen, xxxiii (1964), pp. 193-194; (2) Helmut Günther in Welt und Wort, xix (1964), p. 255; (3) Willy Schumann in The German Quarterly, xxxvii (1964), pp. 533-534; (4) L. Simons in Leuvense Bijdragen, liii (1964), pp. 4243 ; (5) Jörg Hienger in Niederdeutsche Mitteilungen, xix-xxi (1963-1965), pp. 346-347; (6) Werner Lincke in Germanistik, vi (1965), pp. 328-329; (7) Werner Neuse in The Modern Languagc Journal, xlix (1965), p. 119; (8) Ernst Loeb in Journal of English and Germanic Philology, lxv (1966), pp. 132-133. Needless to say, I am very heartened by this reception, and I therefore wish to take this opportunity to thank all those who have given thought to my argument and commented on it.

For the book's second edition Appendices 11 and $I I I$ have been augmented. In Appendix II I have added the manuscripts of Storm that have recently come to light; in Appendix 111 I have added and annotated a number of critical studies that have appeared since the publication of the book's first edition. None of the comments that I have received or reviews that were written have given me cause to make any substantial revisions; with the exception of a few minor emendations, the basic text remains unchanged. 
There is one item that needs clarification in this second edition, and that is the book's title. Since two reviewers questioned its appropriateness, I wish to say that I chose it quite intentionally. I wanted my readers to recall to mind Percy Lubbock's Craft of Fiction (London, 1921) and Victor Lange's "Goethe's Craft of Fiction" (in Publications of the English Goethe Society, xxii, 1952-1953).

Percy Lubbock was the first of the modern critics, I believe, to call attention to the importance of comprehending fiction from the viewpoint of the narrator. In his now famous book he wrote: "The whole intricate question of method, in the craft of fiction, I take to be governed by the question of the point of view - the question of the relation in which the narrator stands to the story" (p. 251). This narrator, as Mr. Lubbock went on to say, is not to be mistaken for the author whose existence is exterior to the work he creates and whose mouth becomes stilled by death at the end of his life; if a work of fiction is full of energy, then the narrator must be a living fictional being who, after the author has died, remains alive in the narrative, continuing to speak to his listeners as long as the narrative is read. "If the storyteller is in the story himself," Mr. Lubbock stated, "the author is dramatized; his assertions gain in weight, for they are backed by the presence of the narrator in the pictured scene. It is advantage scored; the author has shifted his responsibility, and it now falls where the reader can see and measure it; the arbitrary quality which may at any time be detected in the author's voice is disguised in the voice of his spokesman. Nothing is now imported into the story from without ; it is self-contained, it has no associations with anyone beyond its circle" (pp. 251-252).

Mr. Lubbock was absolutely right when he insisted that the narrator's manipulating presence should be considered as an integral part of the evoked fictional reality, and that the relation in which the intrinsic narrator stands to the story is the governing factor in a narrative work of art. To separate the narrator from the story would make a narrative unbearably dull. Consequently, it seems to me essential that if we are to understand narrative fiction properly, we must seek to recognize the narrator and discern his relation to the story.

Our task is not made easy, however, if we should attempt to identify him in the person of a reporter, an individual character, in the narrative; for before such a reporter can be introduced to the reader, a narrator has to be present. "By the first stroke," as Mr. Lubbock held, "the narrator was brought into the book and set before the reader" (p. 253). In this very first stroke, therefore, the narrator must be present ; and, accordingly, he must be regarded not as a drawn char- 
acter, but rather as an epic voice, a sustained conception directing the story's character, mood, and meaning.

Victor Lange, who in his now classic essay was the first, to my knowledge, to indicate the cardinal role that such a fictional narrator played in a work of German prose, has referred to this narrator so aptly as a "central poetic intelligence" (p. 47), as an "ever-present organizing intelligence" (p. 61), and as a "poetic, a multiple, intelligence" (p. 62).

It is precisely with this intelligence, of which Mr. Lubbock in his Craft of Fiction and Mr. Lange in "Goethe's Craft of Fiction" have reminded us, that I am concerned in my study of Theodor Storm's fiction; I sought to underline this fact with the title: Theodor Storm's Craft of Fiction.

I cannot end this preface without also stating how much another book, which has come to my attention subsequent to the first edition of Theodor Storm's Craft of Fiction, has strengthened my conviction that it is essential that we be concerned with the narrator, and that it is equally essential that we make certain this intelligence is not confused with the narrative's author. The book is Wayne C. Booth's The Rhetoric of Fiction, Chicago, 1961. Mr. Booth, associated with Ronald S. Crane and the influential Chicago School of Critics, builds on Percy Lubbock's Craft of Fiction and reminds us again, with greater perspicuity, that in every work of narrative fiction there is "an implicit picture of an author who stands behind the scenes, whether as stage manager, as puppeteer, or as an indifferent God, silently paring his fingernails. This implied author is always distinct from the 'real man' - whatever we may take him to be - who creates a superior version of himself, a 'second self,' as he creates his work" (p. 151).

How appropriate it is to be concerned with such an intrinsic intelligence in nineteenth-century German literature has become clearer to me as a result of the recent, significant discovery by Wolfgang Preisendanz that Storm's contemporary and personal friend Gottfried Keller had made especially sure that the readers of his own works would know that it was to the voice of just such a fictional intelligence, and not to the voice of the author, that they were listening. Keller made this unmistakably plain in the fifth chapter of the fourth volume of Der grüne Heinrich, where the reader is succinctly told: Wir aber als die verfassenden Geister dieses Buches können hier nichts tun als das Geschehene berichten ... (Gottfried Keller, Sämtliche Werke, herausgegeben von Jonas Fränkel, xix, Erlenbach-Zürich, 1926, p. 110. See also Wolfgang Preisendanz, Humor als dichterische Einbildungskraft, München, 1963, p. 337 ; and my review of it in Thc German 
Quarterly, xxxviii, 1965, pp. 368-369).

It remains to thank Mrs. Wanda Kennedy and the members of the Committee on Research, University of California, Davis, for their help in making this second edition possible.

University of California

C.A.B.

Davis, California

February 1966 


\section{ACKNOWLEDGEMENTS}

It is a pleasant duty to acknowledge my obligation to others: I am indebted to Dr. Olaf Klose, Director of the Schleswig-Holsteinische Landesbibliothek in Kiel, for the innumerable courtesies that he and his staff extended to me during my many visits there; to Rektor Carl Laage, Secretary of the Theodor-Storm-Gesellschaft in Husum, for his kindness in making the Society's archives available to me; to Dr. Harry Schmidt in Kiel for many stimulating conversations that aided me in arriving at an interpretation of the reference to Jürgen Ovens in Aquis submersus; to Buichereidirektor Ewald Luipke in Braunschweig for information relating to a Storm manuscript in his possession; and to Dr. Hans Steffen in Paris for his efforts expended in the Bibliothèque Nationale to locate letters from Storm to the Russian novelist Turgenev.

I take pleasure also in recording the interest in this study shown by Professor Victor Lange of Princeton University; by Professor Ernst Feise of The Johns Hopkins University; by Miss Margaret Jacobs, Fellow of St. Hugh's College, Oxford; and by Mr. Gilbert Watt McKay, Fellow of St. Peter's College, Oxford.

Finally, I should like to avail myself of this opportunity to express my gratitude to the authorities of the Goethe- und Schiller-Archiv in Weimar and the Stadtbibliothek in Braunschweig for sending me a number of manuscripts; to the Committee on Research in the 
Humanities and Social Sciences of Princeton University for the generous assistance it has given me; and to Professor W. T. H. Jackson, General Editor of The Germanic Review, for kindly permitting me to reprint portions of an article on Storm's In St. Jürgen which appeared in that journal.

Princeton University

C.A.B. April 1963 


\section{TABLE OF CONTENTS}

FRONTISPIECE .................. IV

PREFACE TO SECOND, AUGMENTED EDITION $\quad . \quad . \quad . \quad$ IX

ACKNOWLEDGEMENTS. . . . . . . . . . . . XIII

INTRODUCTION. . . . . . . . . . . . . 3

PART ONE: $A Q U I S S U B M E R S U S$

I. The tension in the core of the narrative design between (1) the awareness that human happiness vanishes with the passing of years and (2) the reassuring feeling that the destructive effects of the passage of time can be overcome with memory . . . . . 11

II. The realization that memory is subject to the ravages of passing time.................. 12

III. The use of the memoir to counteract the realization that memory is subject to the ravages of passing time. . . . . . . . . 18

IV. The fear that the memoir will vanish . . . . . . . . . . . 21

$\mathrm{V}$. The recourse to pictorial commemoration as a means of allaying the fear of the vanishing memoir . . . . . . . . . . . 23

VI. The realization that even pictorial commemoration will not last 26

VII. The use of auxiliary commemorative media as supports for pictorial commemoration . . . . . . . . . . . . . . 31

VIII. The awareness that the auxiliary commemorative media cannot function permanently . . . . . . . . . . . . . 37 
IX. The attempt to suppress every fear with an all-embracing memory. . . . . . . . . . . . . . . . . . . 44

$\mathrm{X}$. The mistrust of the all-embracing memory . . . . . . . 45

PART TWO: IN ST. JURGEN

I. The narrative form of Aquis submersus and the interpretation of In St. Jürgen. . . . . . . . . . . . . . . . . . . . . 57

II. The composition of commemorative tales and their disclosure of a sensitivity to passing time . . . . . . . . . . . . 58

III. The recourse to memory in order to allay the sensitivity to passing time................ . . 62

IV. The premonition that the soothing effect of memory will prove a deception ................

$\mathrm{V}$. The ability and inability to overcome a premonition that the soothing effect of memory is a deception. . . . . . . . . 68

VI. The narrative's musical imagery and setting as devices for transmitting the joy and anguish of being both able and unable to cope with passing time . . . . . . . . . . . .

VII. The narrative's literary prototype and its treatment of the joy and anguish of being both able and unable to cope with passing time ...................... 72

EPILOGUE.................... . 77

NOTES................... 81

\section{APPENDICES}

I. The author's drafts of a conclusion to Aquis submersus, hitherto believed to be lost . . . . . . . . . . . . . . . . 107

II. A list of the various extant manuscripts of Theodor Storm's narrative prose, together with a note about the author's unpublished correspondence . . . . . . . . . . . . . 117

III. The recent criticism of Theodor Storm. . . . . . . . . . . 123

Index of names . . . . . . . . . . . . . . . 138 
INTRODUCTION 



\section{INTRODIUCTION}

THE EMPHASIS UPON THE FICTIONAL NARRATOR IN THEODOR STORM'S TALES

Perhaps the greatest single difference between this study and all others concerned with the prose fiction of Theodor Storm lies in the way it focuses attention upon a fictional narrator. No other discussion of Theodor Storm's tales, be it analysis of an individual narrative or collective treatment of several or all of them, seeks to interpret them with such specific emphasis upon their fictional, omniscient narrator.

In all previous discussions of Theodor Storm's Novellen, when references have been made to a narrator, they have generally occurred in one or more of the following three ways: (1) $\mathrm{He}$ is referred to casually during the retelling of the plot, (2) he is confused with one of the characters in the tale (usually the one who first speaks in the first person), or (3) he is equated with Theodor Storm himself.

The first kind of reference, since it is not systematic, constitutes merely a rhetorical device on the part of an author of a study, and does not really draw attention to a narrator. The second procedure, however, also does not tell us about a fictional, omniscient narrator. Such a narrator is not a narrator within a narrative, but rather the teller of the tale as a whole, who tells his audience about all the characters in it (including the one who 
first speaks in the first person). The third way in which a narrator has been referred to has the advantage of being more comprehensive than the other two. This narrator, here conceived as the author, really seems to be telling his audience about everything in a story, including every individual character who speaks in the first person. But, as literary critics have recently reminded us, the author and the narrator of a work of prose fiction are not identical. ${ }^{1}$ The two are ontologically distinct: one is an historical person, the other a fictional intelligence. If they were not different, narrative fiction would be deprived of the essential component which distinguishes it from drama and poetry; for although these forms, too, have an author, they do not have a fictional, omniscient narrator. ${ }^{2}$

We can think of no better way to illustrate what we mean when we speak of the fictional, omniscient narrator than to refer to the characterization Thomas Mann gives to the narrator of Der Erwählte. In the opening pages of that novel, after we are told that all the bells of Rome are ringing, the question is asked: Wer läutet die Glocken? The answer we receive is as follows: Der Geist der Erzählung - Kann denn der überall sein, hic et ubique, zum Beispiel zugleich auf dem Turme von Sankt Georg ... und droben in Santa Sabina... An hundert weihlichen Orten auf einmal? - Allerdings, das vermag er. Er ist luftig, körperlos, allgegenwärtig, nicht unterworfen dem Unterschiede von Hier und Dort. Er ist es, der spricht: 'Alle Glocken läuteten', und folglich ist er's, der sie läutet. So geistig ist dieser Geist und so abstrakt, dass grammatisch nur in der dritten Person von ihm die Rede sein und es lediglich heissen kann: 'Er ist's.' Und doch kann er sich auch zusammenziehen zur Person... und sich verkörpern in jemandem, der in dieser spricht und spricht: 'Ich bin es. Ich bin der Geist der Erzählung, der... diese Geschichte erzählt.' 
Our concentration upon the fictional narrator of Theodor Storm's tales is, at the same time, a study of his subjective narrative form. The fictional narrator, since he is omniscient, lends form to everything that is told, and, since he lends form to everything that is told, he becomes visible in the personal, subjective way in which all the component elements of narrative are integrated into an individual form. ${ }^{3}$ The fictional narrator and the form of his narrative, therefore, are inseparable. To recognize the fictional narrator is to understand the form, and to understand the form is to recognize the fictional narrator.

To examine Theodor Storm's tales with specific attention to the fictional, omniscient narrator, we feel, constitutes a new avenue of approach to the understanding of his narrative form. Well-known contemporary critics like Paul Böckmann, Richard Brinkmann, Erich Kahler, Victor Lange, and Fritz Martini, to be sure, have made us mindful of the intrinsically subjective nature of narrative form in the Goethean and post-Goethean periods of literary history, ${ }^{4}$ but no one, as yet, has sought to treat Theodor Storm's narrative as a literary form in which a fictional narrator confides his innermost thoughts to an equally fictional audience.

THE METHOD OF PROCEDURE

To study the narrative form of Theodor Storm's prose fiction means to reflect upon an individual narrative as an aesthetic entity, upon the things told in it that give it its personal form. This can only be done with all the phenomenological description that is inherent in a concrete interpretation. But an analysis of only one example can be misleading. What may hold true for a single narrative may not be binding for other tales or for Theodor Storm's prose fiction as a whole. Our method of procedure, therefore, will be to interpret two different narratives, each inde- 
pendent of one another, in such a way that they mutually complement and illuminate each other.

The tales chosen are Aquis submersus, one of the greatest examples of Theodor Storm's fictional craft when it reached maturity, and In St. Jürgen, perhaps the most artistic achievement among the author's early prose creations. ${ }^{5}$

In St. Jürgen has never been the subject of a form-analysis; it has only been treated by other critics briefly within the context of larger investigations, usually of a biographical nature. Aquis submersus, however, has been made the subject of several critical studies. With their help we have made Aquis submersus the crucial part of our inquiry. But there was also another factor that contributed to making an interpretation of Aquis submersus the more important half of our investigation. This was our discovery of the author's handwritten first draft of the tale. The loose, unnumbered folio pages of this manuscript, the wording of which differs considerably from the printed version, were found by us in the Schleswig-Holsteinische Landesbibliothek in Kiel among the pages of a hitherto unknown manuscript of another tale: Carsten Curator. That a first draft of Aquis submersus once existed has been known because of Theodor Storm's reference to its conclusion in a letter to the Austrian literary critic Emil Kuh. ${ }^{6}$ It has been believed, however, to be lost. ${ }^{7}$

The discovery of this draft afforded us the rare opportunity of tracing the development of Aquis submersus, step by step, through three different stages: (1) The first draft, (2) a later handwritten draft, also in the Schleswig-Holsteinische Landesbibliothek (the existence of which has been previously mentioned by two other critics $^{8}$ but which has never been used by any interpreter), and (3) the final printed form, the only version taken into consideration by all other studies. Needless to say, the changes Storm made from version to version proved to be invaluable to our investigation. They, perhaps more than anything else, helped to make us sensitive to the subtleties inherent in the form of the two narratives upon which our study is specifically based. 
What we wish to show by drawing attention to the fictional narrator and to the subjective narrative form in which he confides his innermost thoughts to his fictional audience may be summed up as follows:

The narrator of Theodor Storm's prose fiction is a tormented intelligence, ever oscillating between the two conflicting thoughts by which he is obsessed: his fear of the all-consuming maw of passing time on the one hand, and a soothing knowledge of his ability to overcome his phobia on the other. This inner struggle makes purposeful the most subtle details of Theodor Storm's Novellen and gives to each of them its distinct narrative form.

\footnotetext{
All numerals in the following text, when otherwise not identified, refer to pages in Albert Köster's edition of Theodor Storms Sämtliche Werke, Leipzig, 1919-1924. In the case of Aquis submersus they pertain to volume IV, in the case of In St. Jürgen to volume III. In the quotations from Theodor Storm's unpublished manuscripts no attempt has been made to alter or emend the author's orthography.
} 

PART ONE: AQUIS SUBMERSUS 



\title{
PART ONE: $A Q U I S$ SU BMERSUS
}

\author{
... das Künstlerische besteht ja \\ wesentlich in der Formgebung
}

Theodor Storm, referring to Aquis submersus, in a letter to Karl Storm, Dec. 16, 1876 (unpublished, Schleswig-Holsteinische Landesbibliothek)

I. THE TENSION IN THE CORE OF THE NARRATIVE DESIGN BETWEEN (1) THE AWARENESS THAT HUMAN HAPPINESS VANISHES WITH THE PASSING OF YEARS AND

(2) THE REASSURING FEELING THAT THE DESTRUCTIVE EFFECTS OF THE PASSAGE OF TIME CAN BE OVERCOME WITH MEMORY

\section{The sensitivity to the vanishing of human happiness}

If we turn to that portion of the narrative that is chronologically the earliest (267-272), we discover that the narrator tells of an artist's happy boyhood. We are also made aware of something else: that time plays havoc with the young artist's happiness. With the passing of time, the boy's happy vacations gradually become less carefree and finally come to an end altogether. First a rival appears on the scene (268). Then, after seven more years have passed, ${ }^{9}$ Bas' Ursel begins to make the young man feel unwanted (269). Soon after this, the time for his departure from his happy surroundings arrives (270). As the day begins to draw to a close, he has to take his leave (270); and when the evening sunset appears, he feels compelled to hasten his departure (271). Finally, the passing of five more years makes him lose all contact with the people and scenes associated with this earlier period (272).

The narrator, it may thus be said, appears to be telling his 
listeners about the artist's happy boyhood in order to make them realize that human happiness vanishes as time passes.

\section{The ability to counteract this sensitivity by memory}

There is still another sentiment, however, that seems to be in the narrator's mind while he tells this early part of his story. $\mathrm{He}$ appears to have the reassuring awareness that, in spite of his sensitivity to the destructive effects of passing time, his apprehension can be overcome by the power of memory. This is conveyed to the audience when, on the pages that immediately precede and follow the earliest part of the story, he relates how the artist, five years after his happy boyhood ended, can relive in his memory the same joyful scenes that he had once known $(265-267,272){ }^{10}$ Through recollection the artist can absent himself from his immediate surroundings, feel once more the warmth of his former patron's welcome (265), and enjoy speaking again to the companion of his childhood (267). Even the carefree mood of this by-gone period can be recaptured in memory. The way the narrator colors the image of the artist as he recollects the past makes this quite clear: It is a sunny May day $(265,267)$; he is well dressed (265) and has sufficient funds at hand (265). The gladdening song of birds echoes in his heart $(265,267)$, and he hears a fruit tree whisper to him (267). He is in such a cheerful mood (265) that he brushes all cares aside (266) and likens the scent of surrounding pine trees to delightful memories (267).

\section{THE REALIZATION THAT MEMORY IS SUBJECT TO THE RAVAGES OF PASSING TIME}

Closely interwoven with the portrayal of the narrator's sensitivity to the effects of passing time, and his apparent ability to ease this concern by memory, is the betrayal of this reassurance through his realization that the power of memory is subject to 
the same ravages of passing time that it had seemingly overcome. As the tale progresses beyond its chronological origins, the narrator depicts the gradual but very distinct passing of a lengthy period of time and constantly informs his audience that the artist's recollected joy becomes increasingly diminished with the passage of time (265-267, 272-310, 311-335).

\section{Mirroring of the passing of time in spatial changes; the detrimental effect of these changes on memory}

This new feeling of the narrator becomes first apparent in the way the figure of the recollecting artist is introduced (265-267, 272-279). We are told that he is walking briskly $(265,267)$. Immediately, the element of passing time is added to the picture that the narrator gives of his recollecting character: the steady progression of strides forward mirrors a regular movement of passing time in much the same way as does the ticking of a clock. The passage of time during the walk is further illustrated in the change of the position of the sun. At the beginning of the walk the sun has not yet climbed above the shadow of the forest (265). Toward the end of the same walk the artist passes out of the shadow into the full sunshine (267).

As far as the recollection is concerned, the additional element of passing time has a negative significance. As the walk progresses, the young painter passes through one different setting after the other, in each of which new interests attract his attention and rival with memories to dominate his thoughts. Spatial changes thus mirror changes in time in order to make vivid the detrimental effect of the movement of time on the artist's recollection. ${ }^{11}$

The first such point at which the artist's recollected joy is interrupted occurs when he walks into a setting where he observes the hideous traces of a war which has recently been waged. $\mathrm{He}$ becomes depressed when he sees that the houses in which as a 
boy he had been entertained have been reduced to ashes. He is saddened, furthermore, when he notices that the fields he had formerly seen covered with blooming rye now lie desolate and overrun with weeds (266). As he moves further on, a dark forest brings another thought to disturb his recollected joy: he cannot help from being haunted by the thought of his wolf-like adversary, Wulf (266-267). ${ }^{12}$

The continuity of his recollection is once more broken in the next setting into which the succession of his steps takes him. Here the sight of two rows of gigantic oak trees causes an uncanny feeling of sadness to overcome him (267).

By far the most incisive interruption of his recollected joy, however, comes when he passes through the gateway of the estate on which he had spent the happy vacations of his youth. The bright vision in his memory becomes overshadowed when he notices that the manor has become concealed from sight by the growth of foliage (272). The joy of always being able to be with his patron in thought is shattered by the sadness of finding him dead (273). His ability to relive in his memory the warm welcome and friendship of his patron receives a severe shock when he is welcomed by the howl of savage bloodhounds rushing after him $(272,276)$, and when he discovers that the study, which he remembered as the place where he had received such understanding counsel (270), is now devoid of anything human, as, indeed, the conspicuously empty armchair and the landscape by Ruisdael - a painting in which people are not portrayed - suggest (277). The merriment associated with his memories of Dieterich disappears when he discovers that the steward's hair has turned snow-white and that his eyes have become dull and troubled (272). The serene atmosphere of the setting he formerly liked to recall becomes marred when he notices that wolves, and not farmers, are looking out of several window openings (273). Above all, he is shocked to find that the childhood playmate is not the happy person whom he had remembered but, instead, someone who is pale (274), full of tears $(274,277)$, terror-stricken $(274)$, and over- 
come with wrath and pain (277). Instead of the place of carefree enjoyment he had continued to imagine, the estate, the painter hears, has become a complicated puzzle (278). ${ }^{13}$

\section{Mirroring of the passing of time in the movements of the clock, the changes in the calendar, and the movement of the painter's brush to and fro; the detrimental effect of these movements on memory}

The steps of the artist's walk with their inherent movement of time do not constitute the only way in which the narrator reveals his obsession with the thought that the joy which seemed to be preserved by memory is diminishing with the further passing of time. As soon as the walk episode is terminated, time starts to pass even faster for the recollecting painter (279-310, 311-335). It is not a mere coincidence that the narrator requires much more Erzählzeit, to use Günther Müller's suggestive term, ${ }^{\mathbf{1 4}}$ in order to relate what his reminiscing character sees and does after the walk episode than during it: the amount of Erzählzeit devoted to the subsequent part is approximately fifty-five pages, whereas for the walk episode he needed only nine pages $(265-267,272-279)$. The narrator does this to remind his audience of the passing of time in the subsequent part more strongly than in the earlier one.

He specifically tells his audience how the hours of the clock go by, e.g., Auf dem Tisch ... war die Kerze fast herabgebrannt, und die ... Schlaguhr hatte schon auf Eilf gewarnt (320); Es wurde Dämmerung, es wurde Nacht ... und endlich suchte auch ich mein Lager ... ich fühlte die Glockenschläge durch das Holz der Bettstatt dröhnen, und ich zählete sie alle die ganze Nacht entlang. Doch endlich dämmerte der Morgen (331). ${ }^{15}$

$\mathrm{He}$ tells his listeners also that the days pass one after the other, e.g., am andern Morgen (282), einen Morgen um den andern (318), ${ }^{16}$ in Angsten sahe ich Tag um Tag vergehen (307), am ersten wie an den andern Tagen (284), schon mehrere Tage geschlossen (282), Seit 
dem Begräbnisstage (284).17 The seasons, too, rapidly follow one another. In regular succession they change from late spring in one year to early spring in the next. ${ }^{18}$ Even the years go by swiftly. There are five of them all told: the year between 1661 (265) and 1662 (307), and then the four subsequent years from 1662 to 1666 (311)..$^{19}$

Equally revealing are the movements of the artist's brush to and fro: Und also ... setzete ich meinen Pinsel wieder an; als aber selbiger eine gute Weile hin und wider gegangen... (313). The more he paints, the more the audience is reminded that time is ticking away on his clock. Particularly revealing in this respect is the way in which the narrator tells of the painting of Katharina's portrait: $d u$ sollst mein Bild ja malen, du wirst eine Zeitlang hier verweilen, she says; then the artist continues: mit der Jahreszeit rückte auch die Arbeit vor ... wir hätten itzund die Zeit gern stille stehen lassen ... dennoch floss es durch den Pinsel ... auf die Leinewand ... Und endlich war's doch an der Zeit ... am andern Morgen sollte ich meine Reise antreten ... Die Arbeit [war] ... am Ende ... das Bild [war] bald vollendet (277-288). ${ }^{20}$

So regularly and so persistently does the narrator now describe how time passes for the painter, ${ }^{21}$ that the entire recollected scene quickly becomes far removed from the present. During the walk the narrator showed how the artist's recollected joy was interrupted as time progressed; now, with the further passing of time and with the increased emphasis given to its description, the listeners are made to see that this joy completely disappears from the artist's thoughts.

The narrator illustrates this process by showing how the further passing of time is accompanied by a parallel growth of emotional tension. The more the passing of time is stressed with references to the clock, the calendar, and the movement of the painter's brush, the more the growth of the accompanying emotional tension is emphasized.

Just as before the spatial changes, which mirrored the passing of time, rivaled with memory for domination of the artist's thoughts, 
now the ever-increasing emotional tension, which mirrors an ever more emphasized passing of time, seeks to crowd memory out of his thoughts. The result, however, is even more disastrous than in the case of the spatial changes. In view of the greater emphasis placed upon the passing of time in this instance, the recollected joy, or what was left of it after it had been affected by the spatial changes, is obliterated entirely.

The growth of this emotional tension is made apparent, above all, by the change in the relationship of the artist to Katharina that is brought on by the passing of time. This causes his heart to become startled (290), distracted (299), tortured (333), and fanned with impatience (322); it also causes his heart to burn (335), throb (302), cry (331), and beat like a hammer against his ribs (324); it makes fire sweep through his veins, and his blood pulse hotly through his body (298); it causes his frame to shake, and his teeth to chatter (323); it tears him with savage claws (313); it fills him with agony (327), as well as with pangs of distress (300); it makes him lose control of himself (328), and all but stagger and fall (331).

In addition, this memory-consuming tension is made apparent by the feeling of paternal guilt developing in him with the passing of time. He calls it Culpa Patris. ${ }^{22}$ At the sound of the very words, the audience is told, he feels as if a sharp sword were piercing through his soul (334). ${ }^{23}$

There are also other ways in which the narrator depicts the inflammation of emotional tension in the recollecting artist: the death of his last friend causes him pain (308); he learns that the only person who he had thought could help him (290) is not interested in him after all (310); he feels the enmity of his adversaries more and more;24 and he suffers from his own hallucinations. ${ }^{25}$ Even the reflection of the artist's emotional state in other characters, ${ }^{26}$ and the choice of details of the local color, e.g., witch burning (321-324, 329-330), ${ }^{27}$ seem to be methods employed by the narrator to stress the extent to which emotional tenison consumes the painter's thoughts and crowds out his memories. 
But now, just at the same time as the listeners become aware of how poignantly conscious the narrator is of the evanescent nature of his main character's recollected joy, they are made to realize that the narrator is countervailing his depression through another means of commemoration: the memoir. This becomes apparent when they notice that the tale of the recollected and subsequently vanished joy is interwoven with a parallel narration telling them that the entire story of this recollection is being recalled at a later date. ${ }^{28}$ They are informed that it is being recalled by the artist in old age, i.e., many years after the disappearance of the recollected joy occurred. ${ }^{29}$

\section{The eclecticism of the memoir}

That the narrator is endeavoring to counteract his depression with this new medium of commemoration becomes apparent, too, when the audience realizes just how he has his character recollect this time. The vanished happiness is remembered to the exclusion of everything else. Ostensibly, the artist is remembering his entire past life (311). However, the details of his life are described to the audience with such eclecticism that they only learn about its one important joy. They learn nothing about his early childhood, the period prior to his father's death (267) and prior also to the inception of the joy. Neither are they informed of what happened in his life subsequent to the termination of the joy in 1666 , when he was still a young man..$^{30}$ Even during that portion of his life which is recorded, everything is omitted that does not shed light upon the central joy. ${ }^{31}$ Speaking of the artist's youth, for example, the narrator only tells his audience about the happy summer vacations (267-272) ; where and how, however, the painter spent his time when he was not on vacation is left unsaid. Omitted, furthermore, are most of the events that occurred during 
the periods in which he lived in Holland, far removed from the scenes of his former happiness. These sojourns are either just briefly referred to - on one occasion in less than a page of narrative (307) and another, in but one short paragraph (265) - or

they are skipped over completely, e.g., Seitdem waren fast fünf Jahre dahingegangen (272). In a similar way, the narrator passes hurriedly over the weeks of the artist's illness, e.g., Es war manche Woche danach (305).

\section{The coloring of the memoir}

The narrator's desire to countervail his depression receives further support from the manner in which he colors the description of the joy when it is recalled for the second time. In the new recollection, it appears in an even brighter light than that in which it was originally shown. The narrator accomplishes this in two ways. First, he reduces the elements in the recollection that might mar the joy. As much as he can, he tries to exclude unpleasant and insignificant things. Perhaps the most outstanding example of this is the way in which he has the artist-memorialist omit the many aggravating and fruitless attempts to restore the joy at the time of its vanishing: Was ich von nun an alles und immer doch vergebens unternommen ... das soll nicht hier verzeichnet werden (309). Typical, too, is the artist-memorialist's forgetting an unpleasant remark of Squire Kurt: Was Junker Kurt hierauf entgegnete, ist mir nicht mehr erinnerlich (285). Similarly, we are told how he has forgotten conversations that were disturbing or unimportant as far as the joy is concerned: Was wir gesprochen, wösste ich kaum zu sagen (285); Was dermalen selber ich gesprochen, ist mir schier vergessen (330). Purposely excluded also as irrelevant to the joy is what the painter did when in a trance: Ich weiss nicht mehr, wohin mich damals meine Füsse noch getragen haben (325).

The second way in which the narrator colors the vanished 
recollected joy so as to make it appear in an even brighter light than before is by augmenting the original joy with joyous hopes uttered by the artist-memorialist at the time the subsequent remembering occurs. On several occasions there are inserted into the recollection parenthetical exclamations expressing the wish that joyous things of the past might be relived in eternity, as, for example, the statement the artist-memorialist makes and separates from the rest of his text with hyphens: - möcht ich sie wieder hören, wenn du, mein Gott, mich bald nun rufen lässt aus diesem Erdenthal! - (296). Other such parenthetical exclamations which thus augment the original joy are: mit denen der Höchste ihnen dereinst eine fröhliche Urständ wolle bescheren! (282), and worin ich ... lebe und der Wiedervereinigung mit den vorangegangenen Lieben in Demuth entgegenharre (312).

\section{The permanency of the memoir}

There is still another way in which the narrator reveals his endeavor to countervail his knowledge of the vanishing nature of recollected joy. This is by describing the subsequent recollection as being put down in writing. ${ }^{32}$ In telling his audience this, he discloses his concern with having the joy commemorated in a more permanent and fixed form than incorporeal recollection in the mind. The joy recalled in the tangible form of a memoir, he seems to be trying to convince himself, would be preserved from the diminishing effects of the passing of time. Above all, such a written record would be rescued from the extinction that takes place after the further passage of time when the remembering person grows old and dies. The narrator's intention here is presented quite vividly through the picture he draws of the artist at the time the latter is committing his memories to writing: an aged man, who realizes that the hands of his watch, as he expresses it, will soon stand still, and who hastens because of this to complete the sketch of his life so that it might be kept from passing into oblivion when he dies (311). 
Again, however, even though the narrator is aware of an ability to counteract his consciousness of the evanescent nature of the once recollected joy, he at the same time reveals a fear that the memoir, which could recapture time for him, will, in turn, vanish.

\section{The fading of the memoir}

The handwritten memoir, he tells his listeners, eventually becomes yellow with age (264)..$^{33}$ This means that, although the memoir can keep the recollected joy from fading, it is nevertheless itself destined to fade.

\section{The significance of the proverb}

Very revealing in this respect also is the significance that he ascribes to the Low German proverb: Geliek as Rook un Stoof verswindt, / Also sind ock de Minschenkind. The listeners are told that it hovers in his mind at the time the memoir is written (311). We are told, too, that it stands out on the pages of the memoir: when one of the copybooks containing the memoir comes to light many years after the artist's death, the saying is discovered in the form of a heading on the first page (311). Furthermore, the audience is told that it serves as the key to the memoir's discovery: the finder of the memoir is able to make his discovery only after the sight of the proverb motivates him to enter the house in which the memoir is located (263). As we may observe from these examples, the narrator always refers to the proverb in such a way that it appears to be very much in the foreground when he thinks of the memoir. It is as if he senses very strongly that the words of the proverb apply directly to the memoir. ${ }^{34}$ 


\section{The meaning of the two separate copybooks}

Another artistic device revealing the narrator's apprehensions concerning the eventual inability of the memoir to retain the past is the description of the memoir as two separate copybooks. The narrator is very anxious to have his listeners know that the memoir does not exist as one unit but as two separate entities, each containing a part of the story that together they jointly retell. He tells his audience, for example, at the end of the reading of the first part: Hier schliesst das erste Heft der Handschrift (310); and before he imparts the contents of the second one: Sinnend nahm ich das zweite und zugleich letzte Heft... (311).

It should also be mentioned that in the second handwritten draft of the narrative a visual method is used to stress the idea that the memoir has two distinct parts. Twice - at the beginning of the first part and, again, just before the second part starts we find written in Roman script, which contrasts with the German of the rest of the draft, the words: Ein kleiner Zwischenraum. Dann verziertes Initial. These words are underlined. Each time, too, the first letter of the following text is highly decorative. There can be no doubt how carefully the audience is reminded that the memoir has two beginnings.

The underlying reason for this, we believe, is to make the audience aware of how insubstantial the narrator considers the memoir to be. In separate copybooks insecurely bound together, the two parts of the memoir can and, according to the narrator's way of thinking, most likely will become detached from one another after the passing of time. ${ }^{35}$

\section{The references to the memoir's fragmentary nature in the unpublished conclusion}

The same apprehension is disclosed to the listeners in a very telling manner in the narrative's lengthy conclusion, which was 
never printed but which is to be found in the first handwritten draft of the tale. There the narrator lets the character who reads the memoir state: Meiner Neugierde hatte die Vergangenheit mit reicher Kunde geantwortet; jetzt, da ich für jene längst Gewesenen in eine fast leidenschaftliche Theilnahme hineingerissen worden, schwieg sie hartnäckig (see Appendix I, p. 113). By putting this statement into his character's mouth, the narrator makes quite plain his realization that the memoir could not, after all, totally recapture the past. Only a part of the past has been kept. A further statement of the same character serves to impress this realization upon the listeners more firmly: Aber noch einmal wie wohl vergebens durchsuchte ich dann die Blätter der kl. Lade (denn noch viele Fragen drängten auf mich ein ... (see Appendix I, p. 111). Once more the audience is told that when the character reading the memoir tries to reconstruct the past retained therein, he is unable to do so completely: the pages of the memoir he has found, he is obliged to realize, have only preserved the story of the past fragmentarily.

\section{THE RECOURSE TO PICTORIAL COMMEMORATION AS A MEANS OF ALLAYING THE FEAR OF THE VANISHING MEMOIR}

At the same time as the listeners sense the narrator's fear that the memoir will disappear, they are made to feel that he is also striving to allay this fear by resorting to another commemorative medium. This time he has recourse to the most vivid means of recalling the past that he knows: painting.

\section{The tranquilizing effect of painting in general}

The narrator's great confidence in the pictorial means of keeping the past from vanishing and, in the face of his consuming fear of passing time, the sense of support he draws from it are clearly emphasized throughout the narrative. 
These concerns come to the fore when the audience is told that the main character is an artist and that all the pictures he paints are expressly made to serve as reminders of people or, as in the case of one of these paintings, of a particular place. We are told, for instance, that he copies the face of his dead patron [um] die bald vergehenden $Z$ üge festzuhalten (274). The artist makes a second likeness so that he can constantly remind himself of his patron's benevolence (281). Katharina and the Amsterdam merchant are painted in order that their families might continue to see them in their absence $(275,307)$. The paintings of the pastor and of the boy, of the clergy in the church, and of the ancestors in the castle, are supposed to recall them to posterity after their death $(280,314,317,330) .{ }^{36}$ The picture of Lazarus, painted while the artist is characteristically rückwärts sinnend, is completed in order to keep the memories of both the distiller and the patron alive (311-313). And the drawing of the mansion, to mention yet another picture, is sketched so that Katharina will not be deprived of its sight when she is away (302). ${ }^{37}$

Similarly, the narrator's confidence in the pictorial means of retaining the past comes to the fore when he mentions in his story the names of two seventeenth-century painters: Bartholomeus van der Helst $(265,298,307,317)$ and Jürgen Ovens (280). Their paintings, quite like those of the artist in Storm's narrative, recapture so much of the past that they serve as reminders for future generations. Van der Helst is noted for his ability as a portraitist, i.e., he gave permanence on canvas to the likenesses of specific people of his time. ${ }^{38}$ Ovens is a painter who, specifically because of his strong religious belief in the transitoriness of earthly things, attempted to memorialize these for posterity. Almost all of his paintings that do not have religious themes are reminders of events and personages that he knew. ${ }^{39}$

The narrator's confidence in painting is, furthermore, made apparent when he tells his audience again and again how life-sized, vigorously painted portraits can have the effect of concrete reality. The paintings of the mother and the father, we are given to 
understand, can make observers of a later age still feel the grace, charm, and companionship for which they were known in their lifetime (280-281); the painting of Katharina can make its viewer believe that she is still standing before him as she once had done (333) $; 0$ and the portrait of the ancestress makes those who are in the room where it hangs experience the same animosity that she had aroused when she was alive $(281,286-287){ }^{41}$

\section{The painting made to remind its viewer of the identical story that the memoir was supposed to recall}

The greatest support that the narrator receives from painting, however, comes when he tries to show how it could counteract his misgivings concerning the disintegration of the memoir. $\mathrm{He}$ tells his audience of a painting that was made in order to remind its viewer of the identical story contained in the memoir (263-264, 281,311 ), but which, unlike the memoir, has not deteriorated over the years (263). This is further brought out when he refers to the same painting as fortifying the memoir's ability to recall the past. He tells his listeners, for example, that the painting hangs in such a way that it appears to keep faithful watch over the memoir (263) ${ }^{42}$ and, by mentioning this, he lets them know that he thinks of it as preventing the memoir from becoming forgotten. He tells his listeners, too, that the painting appears to watch over the reader of the memoir, and that it even reminds him, when he interrupts his reading, to go on with it in order that all the details of the past may be recalled $(264,311)$. This reveals that it is not just the memoir but rather, more particularly, the story contained therein that is being protected by the painting. Furthermore, the audience is told - and this seems to be the strongest evidence for the use of the painting as a means of securing the memoir's recapture of the past - that the memoir is brought to light again only because the painting can arouse the viewer's curiosity to such an extent that he takes hold of the box in which the memoir lies buried (264). 
VI. THE REALIZATION THAT EVEN PICTORIAL

COMMEMORATION WILL NOT LAST

But again, even though the narrator makes his audience realize that he can counteract his fear of the memoir's disintegration by resorting to painting, he also does not fail to let them see that even this, his most vivid means of restoring the past, is not lasting.

\section{The shadow over the painting}

The first clue that we have of this is when he tells of a shadow which hangs over the painting designed to recall the story contained in the memoir (263). Since this "shadowing" takes place a century after the picture was painted, we are given to understand that the painting is no longer as vivid to its spectators as it once was. Such a revelation, in turn, brings to light the narrator's doubt about the continued ability of the painting to keep the memory of the past alive.

\section{The ominous encirclement of the painting}

There are additional expressions of this doubt. A century later, the audience is told, the same painting is encircled by an atmosphere of death. Everything the audience learns about the room in which it hangs suggests this. Both the room's inhabitant and his descendant died and, as a result, the room stood vacant and was closed off for many years. In it there are antiquated furnishings, which had become meaningless to a later generation and are therefore referred to as Siebensachen, and papers that have become yellow with age. All of these are quite prominently in view, since the room has a very low ceiling (263-264). ${ }^{43}$

This deathly atmosphere immediately surrounding the picture is reinforced when the audience is told that the room is situated 
within a house over whose front door is to be found the following Low German inscription: Gleich so wie Rauch und Staub verschwindt, / Also sind auch die Menschenkind (263-264). Significantly, the narrator - as no previous critic seems to have noticed has translated this motto into the High German language of his listeners in order to emphasize its meaning to them. It is as if there were no escape for the painting from the closed-off, coffinlike room in which it hangs. There can be little doubt that by placing the painting within this atmosphere of death, the narrator wants his audience to understand that his faith in the painting as a lasting memorial is destined to crumble.

This impression is further confirmed when we note that the narrator surrounds other paintings in his story with a similar atmosphere of death. It is not, therefore, just this one example that he feels will not last, but rather it is his faith in painting as a preserving medium that is questioned. Referring to the paintings in the portrait gallery, he states that in this capacious room there is but a single spectator, whose only company consists of motes of dust which play in the sun's rays among shadows of the dead (281). This last is the most revealing part of the statement: portraits made and hung in the gallery for the express purpose of keeping the memories of dead ancestors alive are enveloped in an atmosphere that is so still that the silent movement of the motes becomes the most dominant activity in the hall. It is really an atmosphere of death which envelops the paintings, for the air is not only deathly still but also filled with lifeless particles that hover, grope and - we should like to add - try to cover the surface of the paintings. In this dusty atmosphere the paintings appear as lost as the figure of the solitary spectator whom the narrator analogously places in the same room. They likewise seem destined to become nothing more than Schatten, a word, as we have just seen, which is also used in connection with the main painting ;44 that is, through the passing of time so bedimmed by dust that they become gradually less and less discernible to the spectators' view. 
The idea that the portraits are becoming darkened by the passing of time is supported by our knowledge of the genesis of the narrative. As E. O. Wooley has ascertained, the paintings that had stimulated Storm to write Aquis submersus had likewise become darkened through the passage of time. ${ }^{45}$ Undoubtedly, the author had them in mind while writing this particular scene.

\section{The portrayal of death within the painting}

Another means with which the narrator makes his audience more aware of his fear that pictorial commemoration will not last is the portrayal of death within the painting. The suggestion of death that is inherent in the atmosphere surrounding the painting also appears to be present in the picture itself. Not only does the narrator want his audience to know that a deathlike atmosphere encroaches upon the painting from without; he also wishes his listeners to see that a similar effect is produced from within. The description of the environment in which the painting hangs, we noticed, reveals the former. We are made aware of the latter by the portrayal of death within the painting.

The two characters portrayed in the picture have been long since dead. Thus, dead men are its theme. The most unusual thing about the picture, however, and that which, as we are specifically told, constitutes the source of its charm for the spectator is that one of the dead characters is also depicted as dead. The narrator strongly emphasizes this visible representation of death in the form of a corpse: der Tod [hatte] ihm die Augen zugedrückt; he is blass; and he has a schlaff herabhängende Hand (264). The prominence in the portrait of this death-signifying hand, moreover, is underlined by our knowledge that Storm's hand-imagery is among the most consciously designed in German literature. ${ }^{46}$

But prominent as it may be, this very obvious representation of death is not the only way in which the narrator makes his 
audience aware of the deathly atmosphere within the portrait. $\mathrm{He}$ informs them, in addition, that the hand of the corpse is holding a white waterlily (264), a flower which, because of its paleness and the connotations of its cold, damp, and scentless growth in dark waters (of death), ${ }^{47}$ is, as Thea Müller has said, a Totenblume. ${ }^{48}$

Thus, there is another symbol of death in the picture and, we night add, a very striking one, for it is indeed startling to see such a flower in the hand of a corpse (witness the two different viewers who are startled by another painting of a corpse holding such a flower - 260, 334). It becomes even more striking when we learn that such a flower is very unusual in the region (333), and that in the painting Storm used as a prototype for this picture the flower was a red carnation. ${ }^{49}$

The unusual effect the narrator wants the flower to have only serves to show once more how much he desires his audience to be aware of the atmosphere of death within the picture as well as around it.

\section{The inability of the painting to recall the past a century later}

There is yet another way in which the narrator reveals his doubts about the ability of this painting to recapture the past permanently. The audience is informed that a century later the man who is both the possessor of the painting and a descendant of its painter is completely unmoved by it and does not even seem to know whom or what it represents (263-264). This is really a rather strong confirmation of the narrator's fear, for it lets his listeners know that as far as one viewer is concerned - and since he is both the possessor of the portrait and a descendant of its painter, he is an important viewer - the painting has completely lost its ability to recall the past in the way the artist had intended it to do. 


\section{The use of other paintings to support the realization that pictorial commemoration will not last}

We have already shown, while referring to the atmosphere of death surrounding the main painting, that the narrator describes other paintings as having a similar atmosphere. This supported our contention that he quite consciously uses the atmosphere of death to reveal his doubts about the permanence of the painting on which he had once set such great store. There are also a great many other paintings mentioned in the narrative, however, that reinforce his doubt through what is said about them.

Very revealing, for instance, is the portrait of Katharina. It is made for the express purpose of perpetuating her memory in her ancestral home after she herself had left it (275). But it is not able to do this for very long. The audience learns that it is removed after a time from the home (333) and then placed in an environment suggesting the atmosphere of death, i.e., in a house containing large, almost empty rooms whose walls are whitewashed and bare (332), where it is as still as death (332), where the chill of death is present (332), and where another painting admonishes men that everything turns to dust (330). This house, in turn, is located in a lonely village (335), where Satan is supposed to go from house to house (318), where the inhabitants are preoccupied with the killing of witches $(323,324)$, and where another work of art falls prey to hostile, destructive hands (318). It is situated between houses whose thatched roofs have been blackened with the passing of time (316); and it is surrounded by an awful infinity (317), and by a landscape that has become desolate $(316,334)$. The lonely village, in turn, is close by a rumbling sea, which has caused hundreds of people to perish, and which, as indicated by its deceptive silver color, ${ }^{50}$ constantly threatens everything near its shore $(257,317,318,322,323,325$, 335). ${ }^{51}$

Likewise threatened by this atmosphere are the portraits of the clergy, which were painted in order to perpetuate their memo- 
ries in the church they had served $(314,316,317)$. The church is located in that same geographical region to which Katharina's portrait had been removed, and, thus, the danger surrounding her picture also applies to their portraits. The fact that the paragraphs referring to these paintings include sentences telling of death and destruction resulting from the sea's floods (316-318) makes the narrator's intention here all the more obvious.

Menaced also by an atmosphere of death is the commemorative portrait of the ancestress. Like the painting of Katharina, it was supposed to keep her memory alive in the family portrait gallery. But here again the narrator realizes that it could only do so for a limited period of time: several generations later worms had started to eat it away (281).

Perhaps the strongest proof of all for the narrator's fear that painting will not succeed as a commemorative device is what he tells us in the conclusion of the narrative. We learn that the painting of Lazarus, which had helped to perpetuate the memories of two different men (311-313), was sold and had then disappeared. In a later century, the church in which it had hung was itself demolished; the waters of time, as the concluding words Aquis submersus (336) reveal, have drowned it in oblivion.

\footnotetext{
VII. THE USE OF AUXILIARY COMMEMORATIVE MEDIA AS SUPPORTS FOR PICTORIAL COMMEMORATION
}

The feeling that paintings will not endure is also contradicted by the narrator, and his audience is made aware of supports he uses to bolster painting as a commemorative medium.

\section{The use of auxiliary paintings as supports}

Perhaps the most arresting of these supports is the medium of painting itself. Paintings, the audience discovers, are used to sustain one another. Auxiliary commemorative pictures become 
a part of the narrative's artistic structure. They seem to assuage the narrator's fear that the memory he had thought perpetuated by means of a painting would, in fact, be blotted out when that painting itself had faded. This is the significance of our being told that the painting attracts its discoverer's attention solely because he has previously seen another painting which recalled the identical likeness $(260,263-264)$. Had the discoverer not seen the earlier portrait, then the painting that later makes him aware of the past would have remained meaningless. He would not have given life to its story and, as a result, it would only have collected more dust as time went on, and become buried even more deeply in the closed-off, coffin-like room where it had been left to its fate. The auxiliary painting prevents this from occurring. ${ }^{52}$

How much the narrator strives to use auxiliary paintings in order to stem his fear about the fading of the pictorial means of commemoration may be seen when he makes use of a secondary auxiliary painting to fortify the effect of the first. Hanging side by side with the auxiliary painting mentioned above is the portrait of a clergyman. It is interesting to note why he refers to this picture. We are told that the viewer cannot find out as much as he wants to about the life and aspirations of the boy depicted in the auxiliary painting, and thinking that the picture hanging next to it might enlighten him, he turns to the latter for help (260).

Thus, the impression is given that the primary auxiliary painting has another, secondary auxiliary companion at its side to help commemorate what it is helping the main portrait to recall. It is as if the narrator were using a double-strength reinforcement as a support for the original painting, and as if he were making a double effort to curb his fear about the fading of that means of commemoration. ${ }^{53}$

The audience is given a similar impression by means of a parallel construction in another part of the narrative. Ovens' likeness of Gerhardus, we are told, is reproduced on a reduced scale by the artist in order that he might be better able to visualize the likeness when, after the passing of time, he will no longer remain in the 
manor. At a later date, this reproduction is copied on a larger canvas in order that the features of Gerhardus can be remembered more as they originally had been: life-sized (280-281). Here again two auxiliary paintings in succession are employed to recall what is memorialized by a previous painting and to perpetuate a particular memory more securely. And we are again made aware of a double effort on the part of the narrator to curb his fear about the fading of painting by means of the same medium of commemoration. ${ }^{54}$

\section{The use of the memoir as a support}

Arresting as this use of auxiliary paintings is as a means of assuaging the narrator's fear about the fading of pictorial memories, it does not, however, constitute the only support he employs for this purpose. Another such prop is the memoir.

We previously referred to the memoir as a memorial perpetuating the artist's story. Eventually, as we also pointed out, the narrator realized it would not last, and endeavored to support it with the pictorial means of commemoration. This, we should now like to explain, is ambivalent, for the converse holds true as well. The memoir is not only supported by painting, but is a support for painting. When the narrator becomes aware of the inefficacy of painting in permanently recalling the past, he makes use of the memoir as a prop.

The audience is told for example that immediately after the viewer had seen the picture, he began to read the memoir (264). Then, after he has finished reading the first part of the memoir, he again turns to the painting; and tells us that he has no doubt about the subject of the portrait: Hier schliesst das erste Heft der Handschrift... Meine Augen ruhten auf dem alten Bild mir gegenüber; ich konnte nicht zweifeln, der schöne ernste Mann war Herr Gerhardus (310-311). The memoir, therefore, informs him of the identity of the man depicted in the painting and serves as a support for the painting. ${ }^{55}$ 
In the case of the likeness of the boy the matter is similar, even though we are not explicitly told so. We learn that the spectator, just before he starts to read the memoir's second part, asks himself who the boy might be (311). The narrator does not specifically state, as he did in the case of the man in the picture, whether he finds the answer, but since the memoir's second part is to a great extent concerned with the boy, no doubt whatsoever is left in our minds that the viewer, after having read the memoir, has learned the boy's identity. ${ }^{56}$ Again the memoir helps him to understand something recalled, but not made clear, by the portrait. Again, too, the listeners see its function as auxiliary to the portrait.

Besides functioning as a support for the main portrait, the memoir acts as a prop for the two paintings that are used as props for the main portrait. The auxiliary paintings are alone not able to remind their viewer of all of the history they have jointly helped to recapture. After the passing of time, neither one can reveal to the viewer anything about its origin; neither, furthermore, is able to enlighten him about the meaning of the inscription on the one of them (261-262). Only with the help of the memoir, the audience is told, can he learn these things. ${ }^{57}$

Thus, we have in respect to the primary auxiliary painting another double system of supports: the memoir assists the painting, which, in turn, assists the main commemorative portrait; in respect to the secondary auxiliary painting, we have a triple set of supports: the memoir makes the meaning of the painting clear, which, in turn, helps to clarify the meaning of the portrait that supports the main commemorative painting.

Not only do these double and triple systems of supports suggest doubly and triply intensified efforts on the narrator's part to assuage his fear that painting is ephemeral; they also convey something else to his audience. In view of the fact that a non-pictorial commemorative medium is used as a support for a chain of pictorial props, it seems as if the narrator were making an endeavor to preclude the possibility that the past memorialized in painting 
might become forgotten, should even all the pictorial props, one after the other, fade.

\section{The use of popular tradition as a support}

The same impression is given to us by another support he uses: popular tradition. Parallel to and independent of its pictorial and written counterparts, there exists another recollection that recalls the same story. It is the recollection of an entire people in the form of a popular tradition.

The audience is told that the child who has been commemorated both in painting and in writing, so gehe noch heute die Sage, has drowned (260). This implies that the child is remembered not only in the paintings and in the memoir but in a popular tradition as well. The audience is also informed (in the second handwritten draft of the narrative, variation of 260, line 31) that, abgesehen von jener Sage, any memory of the child's stepfather has been obliterated in the village where he had lived. And since his memory has likewise been recalled in painting and in writing, the listeners are, thus, again given to understand that the popular tradition constitutes a third means of perpetuating what is recalled in painting and writing. It might be added that the parallel nature of the popular tradition and the paintings is also emphasized (for, as the second handwritten draft reveals, the author quite consciously added them) by the words: dessen Bildnis jetzt wie mit einer wehmütig holden Sage den ... Kirchenraum erfüllte (261).

What the narrator is giving his listeners to understand when he advises them that the popular tradition recalls the same story as the painted and written commemorative media is that the popular tradition serves as a support to both of the other two media. Should either of them eventually fail to perpetuate the recollection, then, as he indeed feels, there still exists the memory of an entire people to keep it alive. 
But soothing as this thought is for him, it does not constitute the main comfort he draws from his references to a popular tradition. He speaks of this commemorative medium in such a way that it has the appearance of a specific support for that particular painting we had designated as the primary auxiliary portrait.

On each of the two occasions that the popular tradition is mentioned in the final version of the Novelle $(260,261)$, it is for the explicit purpose of augmenting the knowledge of what is recalled by that painting, that is to say, the popular tradition can tell something of the past that the painting is not able to do. This is made especially clear when the audience is told that the first two letters of the inscription on the primary auxiliary painting can only be understood by taking das Gerücht zu Hülfe (261) or, as it is expressed in the first draft, by taking die noch lebendige Sage zu Hülfe. Furthermore, the likeness of the boy depicted by the painting makes the spectator curious to know how the boy had died. But from looking at the painting he cannot find out. It is only after he has heard the popular tradition that he learns of the cause of the boy's death (260).

Because the narrator speaks of the popular tradition specifically as a support for the primary auxiliary painting, he gives his listeners an impression that is similar to the one that they earlier received from the use of the memoir. Again they are given to understand that he is referring to a non-pictorial commemorative medium in order to deny any thought that the memory might become lost should even the pictorial prop fade, a fate that he fears will inevitably befall every painted memorial. The listeners are further confirmed in their impression by the fact that the story is passed by popular tradition from one generation to another and is the property of countless numbers of people. Popular tradition, therefore, has the appearence of being able to insure the story's perpetuation indefinitely. 


\section{THE AWARENESS THAT THE AUXILIARY \\ COMMEMORATIVE MEDIA CANNOT FUNCTION PERMANENTLY}

In view of this exertion of effort to bring a great variety of commemorative media into play in order to safeguard the vivid recollections of paintings, it might seem surprising that the narrator should let his audience know that these additional supports, too, will prove to be ineffectual. This is, however, what he unmistakably intends.

\section{Scepticism in regard to the auxiliary paintings}

The very fact that the viewer of the primary auxiliary painting has to turn, as we have just seen, to another auxiliary painting for the information that the first one does not reveal, and then needs the memoir and the popular tradition to learn what both auxiliary paintings cannot make known, is evidence of scepticism in regard to painting as a satisfactory commemorative medium. The narrator's listeners are given to understand that, in his opinion, these two paintings were neither singly nor jointly capable of conveying at a later date all of the story they were supposed to be, and originally were, able to recall $(314,317,330,334)$. The utmost they could later reveal, as we are expressly told, is but a karge Kunde (260); everything else could not be interpreted (261) and had to remain a secret of the past (262).

How strongly, indeed, the narrator feels that the scepticism that he has of paintings applies to the auxiliary paintings may be seen from the way he visualizes these as surrounded by a series of what we might call "concentric circles," each impregnated with an atmosphere of death. Each "circle" seemingly fortifies the death-filled atmosphere of the "circle" that it encloses and thereby prevents any possibility of escape.

This tightly-sealed, ominous "encirclement" of the auxiliary paintings, which ensures, as it were, the eventual destruction of these pictures by the havoc of passing time, leaves little doubt in our minds about the narrator's feeling. It is futile to entertain 
any hope that these paintings might remain forever present in a viewer's gaze.

The first of these dark "circles" within which the narrator visualizes the auxiliary paintings is suggested by the church in which they hang. Parallel to the entombment of the main portrait in a coffin-like atmosphere, the auxiliary pictures are locked off from the light of day and the activities of the present in a church that has the chilly, mysterious air of a remote and dead past like that of a tomb.

The audience is told that when the old, closed-off structure, built of cold, heavy granite blocks (259) - already suggestive of a vault - is opened by a huge key (259), symbolizing an age long since buried and forgotten, a remote dead past, in which icy silence prevails, ${ }^{58}$ stares at the living about to enter (259). Inside everything is gloomy (261), melancholy (261), mysterious (260), uncanny (260), and, as Ernst Feise has pointed out, symbolic of the dead past. ${ }^{59}$ The tomb-like atmosphere becomes further intensified when the narrator contrasts it with the neighboring parsonage where, quite to the contrary, everything reflects a bright, friendly life in the present day (261).

Encircling this tomb, in which the pictures seem to be buried, and separating it from the active life of the present, which is represented by the city (257), is a landscape where everything speaks eloquently of the decay, destruction, and death wrought by passing time. There are three distinct areas in this landscape, which make, together with the church which they in turn "encircle," four "concentric circles" around the pictures.

Immediately surrounding the tomb and constituting the second of the "circles," is a region in which there are houses described as being hoch zu Jahren, suffering from Altersschwäche, and long in need of replacement (261). Their once light-colored thatched roofs have become darkened by the moss that has grown over them (258). Trees are stunted (259) or are found in the form of left-over stumps (258). The soil, moreover, has become so poor that flowers cannot thrive in it (259). 
The portrayal of the decay and desolation wrought by passing time becomes all the more obvious once the listeners realize that Storm, according to his own statement, has changed the landscape that served as the prototype for the description here in such a way that the two bear little resemblance to one another. ${ }^{60}$ This means that the atmosphere of this "circle" is intentionally portrayed as death-like.

The immediate vicinity around the tomb, melancholic as it is, is surrounded by another area, the third "circle," which seems to be even more desolate. It is described as being bleak (257) and devoid of inhabitants (the only thing that can be seen is a distant windmill-261). It is covered with dry stalks that are overrun with carnivorous beetles (257), and it is threatened by a treacherous sea that had once swept over many of the houses and much of the land, which, in fact, had originally belonged to an island visible on the horizon $(257,317,318,322,323,325,335)$.

Further sealing off the tomb from the contemporaneity of the city is another desolate area, the fourth "circle," which, as the audience is told, has been neglected as far back as anyone can remember. In this "circle," hedges, which were once stubby and well-trimmed, have become thin, spectral barriers no longer bearing any foliage. In it, too, a fishpond has dried up. Finally, the narrator tells us, this wasteland was once the setting of an elegant ducal court that has ceased to exist (257). ${ }^{61}$

In addition to this lengthy and graphic description of the menacing environment in which the auxiliary paintings are located, there are also details in the pictures themselves that reveal the narrator's scepticism about their permanency. Perhaps the most telling of these are the darkening spots on the paintings. The corner of the painting of the boy had become so dark that the red letters of the inscription have become hardly visible (261) ${ }^{\mathbf{6 2}}$ the references to the portrait of the clergyman contain six times such adjectives as dunkel, finster, schwarz, and dïster $(260,262)$. This means that these two paintings are not only being encroached upon from without by the havoc of passing time, 
but that they are also in the process of being destroyed from within by this menace: the likenesses and stories that they are supposed to help perpetuate are being blackened and obliterated by internal disintegration. This is so closely analogous to what we had observed in connection with the dark shadow hanging over the main painting that the reader becomes even more convinced that the narrator is referring to the same kind of obliteration when he speaks of darkening spots on the auxiliary paintings.

There is also another characteristic of his description of the auxiliary paintings that bespeaks his lack of faith in these as permanent memorials. It is the theme of death, a theme that, as we previously pointed out, also plays a considerable role in betraying his scepticism of the main portrait. This time, however, it is stressed to an even greater degree, making it plain that he is more sensitive to the atmosphere of death that envelops these than he has been in the case of the painting they support. It is as if the more he seeks to insure the permanency of memory, the more he feels the pain of knowing his efforts to be in vain.

A comparison of the first auxiliary painting with the main portrait makes the more important role that death plays in the former readily apparent. Like the main painting, the first auxiliary picture also depicts the dead body of a boy who holds the flower of death in his hand. Unlike the main painting, however, the auxiliary painting does not portray the boy in the soothing arms of a kind-looking, elderly gentleman (264), but instead as lying on a bier in such a way that the frightening dread of death can still be read in his face (260). In comparison with the main commemorative painting, therefore, the atmosphere of death in the first auxiliary portrait is suggested not only by the corpse with the symbol of death in its hand, but also in the immediacy of a death that has just occurred, as the body lying freshly on its bier with the agony of death still imprinted on its face reveals.

The greater degree to which the death theme is stressed in the auxiliary paintings may also be seen in the description of the 
second of these. Just as in the case of the first auxiliary picture, there is nothing here that softens the harsh atmosphere of death by something corresponding to the soothing arms of the gentleman. On the contrary, the frightening brutality of death is emphasized perhaps more in connection with this painting than with any other picture described in the narrative. We are not only told that the clergyman depicted in this portrait is a dead man (262), but also - as is suggested both by the Culpa Patris motif (262) and by his being associated with the cold-blooded mercenaries who cast lots for Christ's garments at the Crucifixion (260) - that he looks like a murderer. In none of the other paintings does the death theme have such a startling air of gruesomeness about it as it does here.

\section{Scepticism in regard to the memoir as a support}

Just as the narrator knows that the auxiliary paintings will prove to be ineffectual in the face of passing time, so, too, he realizes that the memoir will not last as a support for the main portrait.

The narrator's listeners find this knowledge logically inescapable. The memoir that serves as a prop for the painting is, as we have pointed out earlier, identical with the memoir that is supported by that painting; and, as we have also shown, the narrator uses the painting as a support for the memoir because he is convinced that the memoir, by itself, cannot preserve the past which it attempts to perpetuate. In view of this identity, there can be no doubt that he likewise realizes its inability to function permanently as a prop for the painting.

Correspondingly, his scepticism is emphasized by the fact that he uses a popular tradition as a support for the memoir. The memoir's need of an auxiliary commemorative medium in this form is another way in which the audience is reminded of the narrator's lack of faith in its strength. 


\section{Scepticism in regard to popular tradition as a support}

This use of popular tradition as a prop for the memoir does not, however, mean that he has an unqualified confidence in popular tradition as a last resort, as a final, permanent commemorative aid. On the contrary, his feelings toward it are just as mixed as those concerning the memoir and the auxiliary paintings.

The very fragmentary nature of the popular tradition is what betrays this to the listeners. We are told that what is remembered in the popular tradition is extremely meager. The only thing specifically recalled is the meaning of the two letters $A . S$. in the inscription on the first auxiliary painting. The villagers who are the living perpetuation of popular tradition know that the boy portrayed on the picture has drowned (261), but how or why nobody remembers any more. The meaning of the other two letters C.P. is not known (261), and, as a result, the real meaning of the inscription, we are specifically told, remains a secret of the past (262). What was known once, therefore, becomes lost as time goes on and popular tradition is passed from mouth to mouth, from generation to generation.

The same ignorance holds true in respect to the person of the artist. How he had come to the village, what his home or name had been - on these points popular tradition, as it lives on in subsequent generations, can offer no information (262). In the course of time the details have been lost. ${ }^{63}$

An additional fact supporting our contention about the scepticism of the narrator is a curious contradiction in the tale. It is to the credit of Frederic E. Coenen that, of all those who have written on Aquis submersus, he alone has called attention to it. ${ }^{64}$ At one point the narrator tells us that according to popular tradition (So heisst's), the only child of the wife of an ancestor died young (286); and then, on the other hand, he informs us that the same woman's character traits were inherited by a descendant in a later generation (281). But, as Professor Coenen has so astutely observed, how can the character traits of a wife of an 
ancestor be inherited by a descendant when her only child died young? The narrator is evidently contradicting himself, and since he is omniscient, he must be doing it intentionally. There can be only one purpose to this: to tell himself and his audience that either popular tradition or the observation concerning the character traits itself is incorrect. He could mean either, but we have no doubt that he is thinking of popular tradition as being faulty. Its inaccuracy again reveals his lack of faith in its ability as a commemorative medium, which is not only consistent with his scepticism of popular tradition, but which also helps to confirm this scepticism.

\section{The weakness inherent in the auxiliary commemorative media due to their geographical separation from one another}

Besides showing the shortcomings of each of the commemorative props and how they are all subject to the havoc of passing time, there is still another way in which the narrator makes his audience aware of the inability, in the last analysis, of these supports to help keep the memory of the past alive. He does this by geographically separating the places in which they are located.

The auxiliary paintings and the legend are located in one place: a village (260); the memoir, on the other hand, is discovered in the city (264). It is only by chance that someone living in the city has a friend residing in the village and that he, while visiting there, happens to notice the paintings and to hear of the popular tradition (257-262). It is even more of a chance that he happens to enter the house in which the memoir is kept and that he happens to be told about it (263-264). Thus, the audience is informed that the commemorative props are prevented from working together because they are located in two distinct places, and that it is only through a series of accidents that someone becomes aware of all of them. 
Their inherent weakness becomes immediately apparent. Separated from one another after the passing of time, they possess only a very limited strength as supports for the main painting. It is only jointly that they are able to act effectively; and such a joint operation, since it occurs accidentally, rarely repeats itself.

\section{THE ATTEMPT TO SUPPRESS EVERY FEAR WITH AN ALL-EMBRACING MEMORY}

The narrator makes one more desperate effort to suppress his consuming fear of being destroyed by the passing of time. This is his prodigious attempt to overcome the terribly disturbing realization that even the auxiliary commemorative media will fall prey to the passing of time.

The means he employs this time, as we might expect, is again memory, but memory of an altogether different kind than we have yet encountered in our discussion of the Novelle. It is an all-embracing memory portrayed through the image of a man who remembers all the other commemorative media that we have referred to thus far. Everything they recall is made to appear as if collected and retained in the memory of a character trying to pass it on to the audience. The use of the first person right at the beginning of the narrative, the constant shifting between the present and past tenses, and the specific references to the fact that the person is, indeed, recollecting make this quite clear:

In unserem ... waren schon in meiner Knabenzeit ... da sie indessen immerhin noch einige Blätter tragen ... und zumal von uns nachdenklichen Leuten wird ... dort liegt eine von den Stätten meiner Jugend. Der Pastorssohn aus jenem Dorfe besuchte ... Es war damals ... sonst war, so viel ich mich entsinne ... wurde je nach unserer Altersstufe ... Hier wussten wir mit dem den Buben angeborenen Instinkte ... wie ich jetzt meine ... viele Jugendfreuden wuchsen ... spüre ich noch heute in der Erinnerung, wenn jene Zeiten mir lebendig werden ... wir waren derzeit schon Sekundaner ... Während wir die Universität besuchten ... als ich selbst schon in 
meiner Vaterstadt wohnhaft war ... in meiner Schulzeit (257-263).

The particularly strong power that the narrator wishes to ascribe to this all-embracing memory is impressed upon his audience when he says that it, specifically, recapitulates the recollections of the main portrait $(263,264,311)$, of the memoir $(264,265,310$, $311,335)$, and of the other commemorative supports: the two auxiliary paintings $(260,261,262)$ and the popular tradition $(260$, 261). It is as if the all-embracing, personal memory were preserving them within a vault of infinite subjectivity. ${ }^{65}$ As a result, one feels that all the fears that the narrator expressed concerning the evanescence of these means of commemoration are now nullified. ${ }^{66}$

To show further how strongly he feels this all-embracing, personal memory to be a means of nullifying all his fears, the narrator lets his listeners know that, should it, too, grow weak after the passing of time, the person embodying it could subsequently summon up a new memory, recalling and preserving the earlier one and everything it had attempted to retain. Thus, since the original memory would then be locked within another memory, the passing of time would, in fact, have no really devastating effect upon it.

This, we believe, is what the narrator endeavors to convey to his audience when the person remembering everything recalls, contemporaneously, an act of remembering in an earlier part of his life: this person, we are told, recalls that, as a younger man, he remembered his still earlier youth (Der eigenen Jugendzeit gedenkend, schlenderte ich... [263]).

\section{THE MISTRUST OF THE ALL-EMBRACING MEMORY}

As soothing as the recourse to such an all-embracing (and, therefore, seemingly ideal) means of nullifying all his fears must be for the narrator, he, nevertheless, cannot completely suppress his qualms. A closer look at this all-embracing memory, especially in comparison with the way it is depicted in the earlier versions of the Novelle, makes his mistrust of it only too apparent. 


\section{The mirroring of the narrator's mistrust in the disquieting discoveries of the possessor of the all-embracing memory}

The first clue to this mistrust can be found in two experiences of the possessor of the all-embracing memory. There can be no doubt that they reflect the inner scepticism that the narrator harbors in respect to the all-embracing memory, for it is only in connection with it that they receive mention.

One of these experiences is the discovery that every personal memory recalling the clergyman, the boy, and the artist has ceased to exist. Not a single one of the memories that their friends and acquaintances had of them continues to live. On the contrary, such memories have passed away with the individuals who knew them (260-262).

Thus, the medium of personal memory, as the possessor of the all-embracing memory discovers, has fallen prey to the havoc of passing time even more rapidly than have the other commemorative media which recall the same three characters. These media (painting, popular tradition, and the memoir) have continued to survive, at least fragmentarily, long enough for him to become acquainted with them. The personal memories, however, became extinct even before he happens upon the scene.

Perhaps nowhere are we made more explicitly aware of this unsettling discovery than when, in the second draft of the narrative, we are told of the result of an inquiry about the deceased clergyman: Aber im Dorfe war, abgesehen von jener Sage, sein Andenken längst verschollen (variation of 260 , lines $31 \mathrm{ff}$.).

Of the other experience we are informed in the first draft of the Novelle. Here the narrator tells how the possessor of the allembracing memory, to his dismay, discovers that, with one exception, all the individual memories of a certain painting, all the recollections that had kept another commemorative medium alive, had eventually passed out of existence with the deaths of the persons perpetuating these memories. 
The one exception, it could be argued, might serve to mitigate this discovery's disturbing import. Actually, it has just the opposite effect, for it makes the possessor of the all-embracing memory even more conscious of the fate awaiting personal memories. This time he becomes an eyewitness to the obliteration of memory by time. Instead of hearing about it from someone else, he sees it for himself. Specifically, he is made to see that because of the advanced age of the woman who embodies the exception (she is both uralt and a Greisin), and due both to her resultant separation from contemporary life (only after a second visit can she be found) and her impending death, which, under the circumstances, can be nothing less than imminent, her memory must assuredly face extinction through the passing of time. To use the narrator's own words, which indeed make the experience disquietingly vivid: ... aber niemand wusste davon; endlich fand sich eine uralte Frau, welche einst in ihrer Jugend bei dem Vorgänger von meines Freundes Vater in Dienst gestanden hatte. Diese erinnerte freilich ein Bild, wie ich es ihr beschrieb, derzeit auf dem Kirchenboden wohl gesehen zu haben, aber es seien von den Ratten grosse Löcher darin gervesen; endlich bei ein Reparatur des Daches sei es fortgeschafft $u$. des Predigers Kinder hätten sich aus der bemalten Leinewand ein Zelt gemacht. 'Wer' - so schloss die Greisin ihren halb unwillig abgestatteten Bericht - regardirt auf solch alte Familienportraiten, wenn die Freundschaft ausgestorben ist!' (see Appendix I, p. 113).

We said at the beginning of our discussion of these two discoveries that they reflect the inner scepticism that the narrator harbors in respect to the all-embracing memory. This scepticism is shown by a process of analogy. The narrator shows on two different occasions that all personal memories, through the passing of time, have either ceased to exist or are most assuredly facing extinction; he cannot but feel, therefore, that the imaginative memory, which embraces these memories, and to which these are inextricably bound, will be subject to a similar fate. ${ }^{67}$ 


\section{The mirroring of the narrator's mistrust in the}

frame-like form of the all-embracing memory

A further clue to the narrator's disquieting mistrust is to be found in the portrayal of the all-embracing memory itself, particularly in the way it appears to frame all the other memories in the narrative.

The unusual feature about this framework is its incomplete or open form. We are told about it before and at the interruption of the narration of the other memories (257-265, 310-311), but not, significantly, at their conclusion. At that point the possessor of the all-embracing memory does not appear again. Such a frame, open at one end, is all the more remarkable since it constitutes a deviation from the usual and most natural type of frame around a Novelle, ${ }^{68}$ and, as a comparison with the handwritten drafts of Aquis submersus reveals, is a very intentional one at that. ${ }^{69}$

This open frame makes a singular discrepancy apparent. On the one hand, the narrator gives his audience to understand that the all-embracing memory encloses and preserves within it all the other memories; and then, on the other, he lets them know by means of a frame left open at one end that it does not completely embrace these other memories after all. But why this discrepancy? If he had an unreserved faith in the all-embracing memory, why does he not use a closed frame that could serve to give testimony to that faith? We can only conclude that he is letting his audience know by means of the open frame that he does not possess such a faith.

\section{The mirroring of the narrator's mistrust in his final thought}

A stronger expression of this lack of faith, in fact, the most emphatic of all, is the narrator's final thought (335-336), the statement that concludes the narrative, but which does not consti- 
tute a terminal part of the frame mentioned at the beginning and during the intermission of the all-embracing memory. In this final statement the audience is told that he is utterly resigned to believing that none of the commemorative media will remain.

When we examine the final thought with regard to the creative process that made it possible, we become particularly aware of this attitude of utter resignation. Storm, whose views were probably not at all at variance with those of the fictional narrator, made many changes in this part of the Novelle, and every time he emended his manuscript, this attitude was further emphasized.

As we mentioned earlier, it was through a comparison of the handwritten drafts of Aquis submersus with the narrative's final, printed version that we came to realize the frame was left open intentionally. In the earliest version an attempt was made to give the frame a concluding part. While Storm was formulating it, however, he felt compelled to interrupt his work and to express an altogether different idea, which, instead of telling us that all the other commemorative media are being recalled in an allembracing memory, gives us to understand that they have been obliterated by the passing of time.

Off to the side of the page of the first draft on which his attempt to conclude the frame is written, we read the following despondent commentary:

Dessen Herr Johannes sich einstens gegen den Junker Wulf ermessen, dass er's wohl auch einmal in seiner Kunst den Grösseren gleich $z u$ thun verhoffe, das sollten Worte bleiben in die leere Luft gesprochen. Wenn Katharina damals, als sie noch beide jung waren, mit ihrem Knaben zugleich gestorben wäre, vielleicht, dass er es dann gewonnen hätte; denn die schwarze Erde hat geheimnisvolle Heilkraft. So - da sie lebte, konnte er nicht zu seiner Kunst gesunden. Sein Name wird nicht genannt, ja selbst in seiner engeren Heimath weiss niemand von einem Maler seines Namens. Sein 'Lazarus', der nur noch in der Chronik unserer Stadt Erwähnung findet, ist nach dem Abbruch der alten Kirche zu Ende des vorigen Jhs mit ihren anderen Kunstschätzen verschleudert worden, der Himmel 
weiss, wohin. Katharinens schönem Jugendbilde, das er selber für sein Meisterstück erkannte habe ich vergebens nachgeforscht; vermuthlich ist es ganz vernichtet. Denn in jenem Dorfe (see Appendix I, pp.110111). Specifically, Storm tells us here that no one knows any longer about the paintings of the person whose story all the commemorative media had jointly perpetuated; even the name of this person, he says, has become unknown. It follows that it must have occurred to him that every medium of commemoration recalling the name and the story has also become extinct.

This new idea apparently played quite strongly on his mind. At any rate, it so disturbed him that it hindered his concluding the all-embracing frame in the way in which he had originally intended. On the next page of the first draft he starts all over again with a different conclusion. Here he tries to do what is perhaps the most logical thing possible under the circumstances: $\mathrm{He}$ attempts to combine the two conflicting ideas.

He does indeed show that the commemorative media are being remembered by someone's all-embracing, frame-like memory. Scenes quite comparable to the ones we meet at the beginning and during the intermission of the frame are depicted:

Sinnend wandte ich $m$. Augen nach dem alten Bilde, das mir gegenüber hing; nun wusste ich freilich jetzt, wen es vorstellte und verstand gar wohl wie es damit gemeint gewesen war. Herr Gerhardus blickte so mild herab, in Grossvaters Arme geborgen schlummerte das Kind mit seiner stillen Blume.

Aber noch einmal ... durchsuchte ich dann die Blätter der kl. Lade (denn noch viele Fragen drängten auf mich ein ... Schon in den nächsten Tagen ging ich auf das Dorf hinaus und besuchte den jungen fremden Pastor, der in einem neuen Hause wohnte. Ich fand hohe wohltapezirte Zimmer, statt der kl. Almanachsbilder hingen schöne Kupferstiche nach Raphael u. Overbeck an den Wänden; nach Süden $u$. Osten statt früher nach Nord u. Westen lagen die Wohnzimmer; es war alles anders. Aber die jungen Pastorsleute waren freundlich gleich den dahingegangenen Freunden meiner Jugend. 
Ich erzählte von meiner Handschrift, wir besuchten zusammen die Kirche in der die alte Zeit geblieben war...

Meiner N'eugierde hatte die Vergangenheit mit reicher Kunde geantwortet... ${ }^{70}$ (see Appendix I, pp. 111-113).

We can, however, also detect the despairing attitude that the allembracing memory is of no avail. What it was supposed to perpetuate has long since gone:

Dessen Herr Johannes sich einstens (im Vollgefühl seiner Kraft) gegen den Junker Wulf vermessen, dass er's wohl auch einmal in s. Kunst den Grösseren gleich zu thun verhoffe, das sollten Worte bleiben in die leere Luft gesprochen... Aber s. Name wird nicht genannt, kaum dürfte er in einem Künstlerlexicon zu finden sein; ja selbst in seiner engeren Heimath weiss niemand von einem Maler dieses $\mathrm{Na}$ mens. Seines grossen Lazarus-Bild thut zwar die Chronik unsrer Stadt Erwähnung. Das Bild selbst aber ist zu Anfang dieses Jahrhunderts nach dem Abbruch unserer alten Kirche wie andere Kunstschätze derselben verschleudert worden $u$. verschwunden.

Auch Ks schönem Jugendbilde, das er selber für s. Meisterstück erkannte, habe ich vergebens nachgespürt...

Und das war alles. Aquis submersus. (see Appendix I, pp. 112-113).

It does not surprise us that Storm is not able to content himself with this attempt to combine the two attitudes. Although logical under the circumstances, it neither bolsters his hopes nor alleviates his feeling of resignation. Again, therefore, he does what is most logical: he begins the conclusion afresh. The second draft of the Novelle makes this clear. He starts out by once more reminding us that everything is being told from an all-embracing, personal memory. The character reading the manuscript and remembering what is contained in it again becomes visible:

Noch cincn kurzen Zusatz enthält die Handschrift; während aber im Vorstehenden eine schon weit dahinten liegende Vergangenheit berichtet wird, ist dagegen diese letzte Aufzeichnung der unmittelbaren Gegenwart entnommen. Schon die noch unsicherer gewordenen Schriftzïge bezeugen es. - Der Schreiber bereits die Schwelle des Greisenalters überschritten hat (see Appendix I, p. 114). 
This is, however, as far as he goes. The feeling of resignation apparently takes possession of him again, for he continues with a very conscious attempt to give expression to that singularly impassioned feeling of evanescence that was known to the poets of the Baroque:

Sie beginnt mit einem Vers, der nach der Weise des Martin Opitz klingt...

Die Lilien und die Rosen, So mit dem Weste kosen;

Das schöne Theyl der Erden

Des Leibes edle Zier -

Zunichte muss es werden

Und geht als Staub herfür. ${ }^{71}$

(see Appendix I, p. 114).

When he reached this point, the feeling of resignation apparently took such complete control of him that he decided to abandon altogether any attempt to conclude the frame as he had originally intended. All of the above is crossed out, and once more a new conclusion is begun.

This time - and it is the final, printed version - he exhibits the strongest and most complete feeling of resignation he has yet shown. ${ }^{72}$ The audience discovers that he not only rejects the attempt to salvage the all-embracing memory, but also the desire to associate himself with that particular type of resignation that was felt by Martin Opitz and the poets of the Baroque. Apparently Opitz' attitude, despondent though it is, suggested too much mitigating hope of a Christian after-life to be entirely compatible with the complete despondency in which he found himself.

All that the audience hears is a stringent statement that succinctly lets them know that every endeavor to keep the past alive - either on the part of Storm, as an analysis of his creative process shows, or on the part of his fictional counterpart, as the language and context of the statement reveal - has come to nought:

Dessen Herr Johannes sich einstens im Vollgefühle seiner Kraft ver- 
messen, dass er's wohl auch einmal in seiner Kunst den Grösseren gleichzutun verhoffe, das sollten Worte bleiben, in die leere Luft gesprochen.

Sein Name gehört nicht zu denen, die genannt werden; kaum dürfte er in einem Künstlerlexikon zu finden sein; ja selbst in seiner engeren Heimat weiss niemand von einem Maler seines Namens. Des grossen Lazarusbildes tut zwar noch die Chronik unserer Stadt Evwähnung, das Bild selbst aber ist zu Anfang dieses Jahrhunderts nach dem Abbruch unserer alten Kirche gleich den anderen Kunstschätzen derselben verschleudert und verschwounden.

Aquis submersus (335-336). 

Part Two: IN ST. JUURGEN 

Part TWo: IN ST. JURGEN

Eins sollte mir leid tun: wenn
meine Dichtung nur 'rührend'
wäre. Sie sollte erschütternd
sein...

Theodor Storm, in a letter to Wilhelm Petersen, July 13, 1876

(Schleswig - Holsteinische Landesbibliothek)

I. THE NARRATIVE FORM OF AQUIS SUBMERSUS

AND THE INTERPRETATION OF I'N ST. JÜRGEN

Analysis of the intricate narrative form of Aquis submersus, one of the most representative Novellen of that later period in Storm's literary career when, as Paul Heyse stated, he began in $O l z u$ malen, ${ }^{73}$ offers the best possible means, we believe, for understanding what the author's earlier tales are about.

In these, the narrator's vexing oscillation between the two forces which rival each other for the domination of his mind is not apparent in the same degree of dynamic tension that is characteristic of Aquis submersus and of most of the tales in the zweite Periode meiner Novellistik, ${ }^{74}$ as Storm himself called it. And since the struggle of the narrator is not as intense, although still present, the narrative patterns of the earlier Novellen are not as intricate. Quite naturally in these tales, the recollections used by the narrator to overcome the effects of passing time are both fewer in number and less complex. They are usually in the form of personal memories of older people recalling former periods in their lives. Sometimes there is but one such memory to a narrative.

While examining an earlier narrative before a later Novelle, one may be tempted to think of the depicted recollection(s) as illustrative of a sentimental attitude on the part of the narrator. Consequently, one may overlook the genuine struggle which it, in spite 
of a less perfect portrayal, is intended to exhibit. The danger of misinterpreting an early narrative, therefore, is great.

However, if one first turns to an early tale after having become aware of the dichotomy of thought inherent in such an exemplary Novelle of the later period as Aquis submersus, instead of proceeding, chronologically, from the less to the more mature narrative, one realizes unmistakably that the early tale portrays the same vexing struggle, though in a less intense way. It is our belief, therefore, that to a great extent understanding one of Storm's early narratives is contingent upon understanding his later masterpieces.

Conversely, the discovery that the torment of the narrator we found so characteristic of Aquis submersus can also lend meaning to the most subtle details of an earlier narrative serves to confirm our interpretation of the later work. This occurs not only because the findings in both mutually complement one another, but also because the later narrative represents an expansion and intensification of what was already present in a germ-like form in the more rudimentary construction.

How our analysis of Aquis submersus helps to understand the form of an earlier narrative, and how the form of an earlier Novelle helps to substantiate our findings in respect to Aquis submersus, the following examination of In St. Jürgen will hopefully show.

II. THE COMPOSITION OF COMMEMORATIVE TALES

AND THEIR DISCLOSURE OF A SENSITIVITY TO PASSING TIME

Like Aquis submersus, the narrative form of In St. Jürgen is determined to a great extent by the commemorative element. Its narrator relates a group of individual commemorative tales. These, in turn, are the memories of other people: a mature man telling what he remembers about two elderly people whom he had known in early youth (72-113); an old woman recapitulating her youth (78-93); an old man recollecting his past (97-110); his wife 
remembering a past event (108); and the old woman's father recalling earlier times $(79,87)$.

In St. Jürgen is similar to Aquis submersus also in that the dominant note in this composition of commemorative tales, aside from commemoration itself, is the disclosure of the narrator's sensitivity to passing time.

In the thirteen pages which contain the old man's recollection, the narrator reveals on no fewer than eleven specific occasions that he is conscious of passing years, e.g., Jahr auf Jahr verging (106), So gingen die Jahre hin (109), nach Jahresfrist (104). ${ }^{75} \mathrm{He}$ is also very often aware of the evanescent nature of the days, weeks, and months, e.g., Am dritten Tage (84), In der letzten Woche (80), einige Monate später (93). ${ }^{76}$

It is to the movement of the clock, however, that he seems to be most sensitive. Robert M. Browning ${ }^{77}$ has pointed to a very striking example: Nichts hörte ich als das Rasseln der grossen Turmuhr... Ich weiss es noch gar wohl, mir grauete dermalen vor diesem toten Dinge, und ich hätte ... in die eisernen Räder greifen mögen, nur um es still zu machen (100).

The narrator is also clock-conscious on many other occasions, e.g., Aber die Zeit drängte; unter uns schlug dröhnend die Viertelglocke (102), fünt vom Turme geschlagen (99), Als ich mich aber mit dem bestimmten Glockenschlage einfand (98), mehrere Stunden später (109).

Very typical, too, is the way in which he is aware of the passing of the hours from evening to morning: je mehr es gegen die Nacht ging ... Da gegen zehn Uhr der Mond aufging ... als es Mitternacht vom Turme schlug ... erst als ich eine Zeitlang geklopft hatte ... Eine Zeitlang stand ich ... Das Licht war ausgebrannt ... Allgemach erblichen am Himmel draussen die Sterne ... der erste Schein des Morgenrotes ... bald wurde es laut im Hause; der Tag war angebrochen ... als die Uhr sechs geschlagen (84-89).

In like manner, the frequent occurrence of indefinite references to passing time makes this sensitivity apparent. Within the Novelle's forty-two pages, for example, the narrator's audience finds 
him employing the word dann no less than thirty-nine times. ${ }^{78}$

The constant aging and maturing of the characters in the story constitutes another way by which we become aware of his sensitivity.

The old woman, for example, is described as a child $(79,98)$, and as a girl with blond hair $(73,90,98)$; later we see her old $(75$, $85,90)$, retired (75), gray-haired (73), and on her sixty-fifth birthday $(76,95)$. This specific anniversary, especially since a birthday in her youth is mentioned in conjunction with it (94), particularly emphasizes her aging.

In a manner paralleling the life span of the old woman, the old man develops from school boy $(79,98,99)$ to apprentice $(79,97$, $103)$, and passes the age of forty (107); later he is an old man (95, $96,97,110,111,113)$ with white hair $(95,105)$, as well as a grandfather (109).

Furthermore, many stations marking the development of the mature man from boyhood are depicted. We see him as a twelve year-old boy $(73,75)$, as a student $(76)$, as a young man $(95)$, and finally as a mature adult (72).

Even the minor characters advance in age during the narration. The wife of the old man is first described as a young woman (103), and then later as a person whose eyes have aged (110). Her sons are first mentioned when they are school boys (103); several pages further the narrator speaks of them as grown-up children (107), and then as parents (109).

Collectively, these characters make up three generations, a sequence that also reflects the narrator's time consciousness, as, indeed, his repeated references to generation sequences emphasize. In the family of Jacob, the audience is also told of three generations $(99,100)$; and in the mature man's family, four generations are portrayed: himself, his mother (111), grandmother $(73,74$, $76,110)$, and great-grandfather $(75,78)$.

The time-sensitivity of the narrator is further conveyed to his audience by the many items referring to past eras. By stressing, for example, the fact that the hospice of St. Jürgen was built 
in the sixteenth century, and that the first reformers preached in its churchyard (72), he manifests his awareness of the passing of the Reformation period as well as of the preceding Catholic era. ${ }^{79}$

Similarly, the references to the continental blockade of 1807 (78) ; to the coming of the steam age (95); to events that occurred in $1549(79)$, and between 1700 and $1721(86) ; 80$ to the replacement forty years earlier of an old church by a modern structure $(73,97)$; and to that dated period when pianos became popular instruments (102), and the best were made in Vienna (103), all help to emphasize his awareness of past ages.

The witchcraft, which is remembered, and then contrasted with contemporary religious practices in order to make it appear outdated (76), also echoes this sensitivity. The same holds true for his mention of the once widely accepted belief in wizards, which is recalled and then ridiculed (83) in order to show that it is very definitely past and quite foreign to the present. ${ }^{81}$ In like manner, the statement about the different way in which public announcements were formerly made in the town (91) is indicative of how aware he is of the passing of history.

His sensitivity to passing time is also disclosed by an apparently non-temporal element in the Novelle: the illogical failure of the two main characters to write to each other.

This failure is quite central to the plot of the narrative, and critics have, quite naturally, pointed to it, thereby underlining its importance. Their reason for doing so, however, has been a negative one. Since all the difficulties of the two main characters, when they are separated, come about because neither ever writes to the other, although they are intelligent and could easily do so, the critics have thought it strange that an otherwise careful author should base the plot of his story on an hypothesis so difficult to accept. ${ }^{82}$

We think this not at all strange. On the contrary, we feel it is quite consistent with the narrative's artistic form. The absence of any logical reason for a failure to correspond is intentional and signifies the absence of the means that could prevent the happi- 
ness of the two main characters from disintegrating. Such an absence, especially when understood in conjunction with the other form-giving elements of the narrative, reveals how much the narrator wants to emphasize that the disintegration is solely a result of the passing of time. What else could be the cause? If there were a logical reason for why neither of the two characters ever write to each other, then the disintegration would not be the result of the passing of time, as the narrator intends, but rather the result of whatever logical cause he might have selected.

Thus, we conclude, the very absence of a logical cause again helps to show how much the narrator wishes to make apparent the passing of time and his own sensitivity to it. That an analogous situation is portrayed in two other of Storm's Novellen, Immensee and Hans und Heinz Kirch, only serves to support our contention that this is all quite intentional. ${ }^{83}$

III. THE RECOURSE TO MEMORY IN ORDER TO

ALLAY THE SENSITIVITY TO PASSING TIME

\section{The significance of the personal memories}

As in Aquis submersus, the audience finds that In St. Jürgen, while making its narrator's sensitivity to passing time apparent, also shows very clearly his determination to countervail this feeling. This is brought to light especially when they notice that he is the reteller of a group of commemorative tales. This means that everything he tells his listeners has previously been recalled from the past by someone else and that, therefore, every single part of his narration constitutes an attempt to show that a past is being retained in the present.

How much and how specifically the individual commemorative tales are intended to illustrate this attempt to countervail his sensitivity to fleeting time may be seen if we turn to the first of these, to the recollection of the mature man (72-113).

In spirit, we are told, he can wander again up the main street 
of the town of his birth and childhood (72). By means of his memory, he can transform himself into a small lad, ${ }^{84}$ and in this changed state, is able to relive a variety of earlier events as though they had not disappeared with the years. In this nostalgic mood, we are furthermore told, he can re-experience the charms of the churchgoing of former times $(73,75-76)$, and, as if in his boyhood, can speak again with one who has long since been dead (73-76). $\mathrm{He}$ can also relive an experience of his student days $(76-95,105)$, as well as a subsequent event (95-113) that has long been a thing of the past, since it had occurred before the stagecoach was superseded by the railroad (95).

The old woman's memory (78-93), too, specifically mirrors the narrator's attempt to counteract his feeling of the progression of time. She can become oblivious of the present and in thought relive the glories of old times until some loud exterior sound, such as a peal of music, again makes her conscious of her present surroundings (75). It is her nature that she can neither forget the dead (78), ${ }^{85}$ nor buildings long since destroyed (79), nor events she experienced in her youth (85). Nor does the narrator let her forget specific joyful and sorrowful events which occurred in her younger days. She remembers them only too well (81) and feels the comfort of them (87), even though they exist only in memory.

The old man's commemorative thoughts (97-110), similarly, do not fail to impress upon us the narrator's ability to countervail his sensitivity. He portrays the old man just as he did the old woman and the mature man: as a person who is able to retain in his imagination a past that has long since ceased to exist (97-103). In the memory of the old man, an old church tower remains standing for many decades after it has been torn down $(97,106)$. In his imagination, the old man can still look with an enraptured expression into the blue eyes he knew in his youth (98) and, having become completely oblivious of his present environment, can hear once more the voice of his former fiancée $(106,109)$, or can be stirred anew by sorrow (105) and mental anguish (109) he experienced in the past. The words of his fiancée's friend live on 
within him fifty years after they have been spoken (98). Like a lost paradise, the town of his youth ever remains before his sight (108). The very shocks (98-99) and horrors (100) that he had felt in his youth are not forgotten: Ich weiss es noch gar wohl, he says (100).

The Novelle's two minor characters, the wife (108) and the old woman's father $(79,87)$, also specifically help to lay bare the same attempt. The wife so carefully preserves in her memory a minute detail of an event that took place many years earlier that she can still feel the long since vanished happiness that was associated with it (108).

Concerning the memories of the old woman's father we are told that, though his wife has been dead for eighteen years, he is still able, subconsciously, to hear and relive the shock of her hysterical death as if it were a thing of the immediate present (87). We are also told that he preserves so well in his memory the religious devotion connected with a past event that he can mentally relive the same situation with an undiminished amount of piety (79).

\section{The significance of pictorial and other means of commemoration}

The narrator's attempt to overcome his sensitivity to fleeting time becomes further apparent in his inclusion of many memorial objects into his narrative. Particularly revealing is the manner in which he describes and utilizes portraits.

For him the banquet hall in the hospice possesses only two ornaments: an antique timepiece, the legacy of a deceased inmate, and a life-sized portrait of the hospice's founder in a scarlet doublet (77-78). The clock reveals his awareness of the flux of time, not only because it registers the passing of time, but also because, as the legacy of a deceased person, it serves as a constant reminder of the passing of human life. On the other hand, in mentioning the scarlet-colored, life-sized portrait of the dead founder, the narrator seems to fire his imagination with the 
thought of a deceased person as though he were alive. Thus, the audience learns that, as if in diametric contrast with the sensitivity symbolized by the clock, the portrait seems to mitigate the negative effect of passing time by keeping the past alive.

A similar endeavor to keep the past and, specifically, the dead alive, is suggested when the narrator refers to two other portraits, described as being not only life-sized, but so life-like that the eyes of each of the dead men seem to look forth into the new age $(76,89)$.

Portraits, however, are not the only memorial objects in In St. Jürgen that reveal an attempt to cling to the past as though it were present. The narrator also tells us that memorial windows keep the past from being forgotten (78); that linden trees serve to help keep the ideas of a former, historical period alive (72); that chronicles prevent the past from sinking into oblivion (76); and that old buildings $(72,79),{ }^{86}$ an old garden (72), and oldfashioned home furnishings $(77,94)$ constantly recall past eras, customs, and happenings for people living in the present.

\section{THE PREMONITION THAT THE SOOTHING EFFECT OF MEMORY WILL PROVE A DECEPTION}

\section{Scepticism in regard to personal memories}

Coupled with this sense of an ability to counteract the effects of fleeting time through the medium of memory is the narrator's awareness that this power will prove deceptive. He knows that in due time memory itself will fall prey to the very force it had seemingly conquered.

This feeling he conveys to his audience most clearly perhaps when he shows how memories become ever fainter through the years and thus lose their ability to retain the past. Both the old man and woman state that they no longer remember certain things $(87,88,92,103)$. The old man's memory leaves other items buried in the past (98); the fervor of his recollection becomes ever more tranquil through the years (109); and the picture in his memory fades eventually into thin air (112). 
It is significant, too, that during the story all five of the characters whose memories perpetuate the past are aging. Moreover, the narrator advises us of the death of three of them from the effects of senility, explicitly in the case of the old woman (111) and her father (93), and implicitly as far as the other old man is concerned (72). This is one of the most effective means the narrator has at his disposal to reveal his premonition that ultimately the stream of time will engulf even the power of memory. $\mathrm{He}$ tells us here that memories are situated in bodies that, in time, will increasingly fall prey to senility and the subsequent dissolution of death.

Another artistic technique that reveals his scepticism in regard to personal memory is his method of enclosing commemorative tales within the framework of a recollection by another person. Through this means we are made to realize that individual retrospection eventually loses its ability to keep the memory of the past alive, and that the retention of this past becomes contingent upon the aid of the auxiliary commemorative tale which frames the first one.

Thus, the events of the past that the father of the old woman kept alive in his memory can, after a further passing of time, be prevented from disappearing into oblivion only by his daughter, who afterwards remembers his recollections; that which remained present in the retrospective thoughts of the daughter and of the other old man, including the recollections of his wife and the above-mentioned father can, after further passage of time, be kept from being lost only by the mature man's later recollection of what they once recalled. The narrator reveals this quite unmistakably when the old woman in telling of her past says to her young listener: $d u$ musst doch von mir wissen, wenn ich nicht mehr bin (79). She knows that the memory of a younger person is necessary, lest the past that her memory has rescued from oblivion be extinguished at the time of her death. ${ }^{87}$

Still another artistic technique used by the narrator to disclose his fears concerning the eventual inability of memory to help him 
thwart the "all-consuming jaws of time," to use Robert M. Browning's expression, ${ }^{88}$ is the device of letting two commemorative tales mutually support each other.

The recollections of the old man and woman bring to light the same aspect of two peoples' lives during an identical span of years. Each tale, however, relates what is omitted in the other ${ }^{\mathbf{8 9}}$ and it is only when the two halves ${ }^{90}$ are pieced together within the recollection that frames them that the whole story, which they jointly recall, is told. ${ }^{91}$ Neither one of these memories, therefore, has the power, after the passing of a certain period of time, to recall all the circumstances of a particular past time.

\section{Scepticism in regard to pictorial and other means of commemoration}

The narrator also does not fail to realize that even the inanimate memorials that serve to keep the past from sinking into oblivion eventually will lose this important ability. He tells us that chronicles, which could once recall the past, have themselves become things of the past (76). The paintings that were able to portray the past to subsequent eras have become rare (74), or have disappeared (75) with the structures that were torn down to make room for more modern buildings $(73,74,75,76,97)$. Even the houses that were daily reminders of former happenings have vanished (79).

Analogous to the framing of one personal memory by another, scepticism in regard to pictorial and other means of commemoration is also revealed when the audience is given to understand that all the inanimate memorials are framed by a personal memory. (Since everything narrated is part of at least one personal memory, the story of every inanimate memorial is likewise retained by at least one personal memory.) This means that the recollection of the past through the use of inanimate memorials is contingent upon one or more personal memories, a fact that makes the inherent weakness of the memorials apparent. 


\section{THE ABILITY AND INABILITY TO OVERCOME A PREMONITION}

THAT THE SOOTHING EFFECT OF MEMORY IS A DECEPTION

\section{The ability to overcome the premonition}

The techniques of enclosing commemorative tales and memorials within the framework of a recollection by another person and of employing two commemorative tales to support one another, while revealing the narrator's scepticism of memory, also make known his attempt to overcome this scepticism. The audience is made to see that the story contained in one commemorative medium, should the latter disintegrate after the passing of years, is protected from oblivion by another commemorative medium that independently recalls the same story.

Thus, for example, we are given to understand that the recollection of the old woman's father does not become extinguished when he dies because it is kept alive by his daughter's memory, which frames it. After her death, together with her memory, it is again rescued from oblivion by being kept alive in the memory of the mature man, who will keep the recollections of the old man and the latter's wife alive after their deaths, since his memory frames these too. Even the stories of all the inanimate memorials, the narrator seems to think, are preserved from oblivion by virtue of their being framed by personal memories.

Similarly, when the recollection of the old man brings to light details the old woman's does not contain and, conversely, the old woman's memory recalls what is not remembered by the old man, we are given to understand that one memory preserves what another, after the passing of time, has lost.

\section{The inability to overcome the premonition}

The ability of the narrator to overcome his scepticism in regard to memory is, however, as he well knows, deceptive. Each of the personal memories which frames or supports another commemo- 
rative medium and preserves it from becoming forgotten belongs to a person who is described as aging. With the eventual dissolution of the personal memory at the time of death, its framing or supporting function will also be lost.

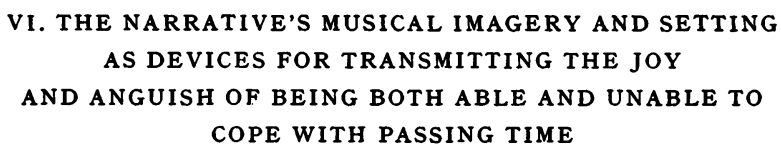

\section{The musical imagery}

Complementing the pattern of In St. Jürgen and localizing it in musical imagery is a kind of chorus to the narrative: the constant appearance and disappearance of swallows. ${ }^{92}$ The importance of this imagery becomes quite apparent when one glances at the first edition of the narrative in book form (published 1868 in Schleswig), one of the rare copies of which is preserved in the archives of the Theodor-Storm-Gesellschaft in Husum. One of the most striking details of this edition is the gilt impressions of swallows on the cover, an external feature which the English translator of the Novelle was anxious to retain, for he changed the title in order to incorporate the word "swallows": The Swallowes of St. Jurgens. ${ }^{93}$

This imagery, in its musical way, renders audible the narrator's oscillation between the two forces that rival each other for the domination of his thoughts. It echoes his sensitivity to passing time; it reveals his joy at knowing that memory offers a possibility of overcoming this sensitivity; and it makes known his anguished realization that even memory will fall prey to the passing of time.

It is especially his awareness of passing time that is emphasized in the depiction of the swallows. When the old man and woman recognize the warning that the quarter-hour bell rings out, a swallow appears to pour forth a flood of rapturous sounds, thereby making the clock's threat more poignant (102). At the mo- 
ment when their happy hours spent together come to an end, the same swallow appears again, this time graphically illustrating the event by spreading out its wings and flying away (103). ${ }^{94}$

It is not by chance that the narrator tells his audience of the spectacular and clamorous arrival of a flock of swallows on the old woman's sixty-fifth birthday (95); neither is it coincidental that swallows follow her when she becomes an inmate of the home for the aged (75) and that the scene depicting her bier is descriptively augmented with references to the departure of swallows (112). ${ }^{95}$ By using these striking background elements to focus attention upon her aging and death, the narrator makes even more apparent his awareness that a lifetime has ebbed away and has, at last, drawn to a close.

In a similar manner, swallows echo the narrator's joy at knowing that the realm of memory offers a possibility for retrieving the past. We are repeatedly informed of this sentiment by the number of sunny, song-filled swallow scenes that occasion and accompany the remembering of the past.

The springtime return of swallows and the belief that they are twittering Rückert's commemorative song: Aus der Jugendzeit, ${ }^{96}$ the narrator tells us, cause the mature man's thoughts to return to his youth (72). ${ }^{97}$ The song of newly arrived swallows in the sunshine of spring accompanies the recollections of the old woman $(75,95)$; their sight provokes her to recall, as her sigh reveals (7475), the happiness that she once enjoyed earlier when swallows had fluttered about her (102). ${ }^{98}$ Similarly, the singing of these birds evokes, year after year, memories of the past in the old man (106-107, 109-110). ${ }^{99}$

But just as swallows are depicted as arriving in the spring to make the commemorative renewal of the past symbolically visible, so they are correspondingly portrayed as departing in the fall in order to stress graphically the eventual inability of memory to retain the past.100 In the scene in which the narrator shows how the memories of the old man and woman become extinct, swallows disappear singing Als ich wiederkam... War alles leer, 
and leave nothing behind but an empty nest (112-113). Significantly, the departure of the birds constitutes the Novelle's conclusion: their departure has a strong connotation of finality.

\section{The setting}

As the $I n$ of the title implies, the importance of the setting within the hospice of St. Jürgen should not be overlooked. It constitutes another artistic means of complementing and localizing the narrative pattern, and of making the audience aware of the narrator's oscillation between two forces. ${ }^{101}$

Above all else, life in St. Jürgen emphasizes sensitivity to passing time. Most of the inmates of the hospice have been retired from active life for such a long time that they have become virtually unknown in the town (75-76). Their clothing is outdated (75); their possessions represent the taste of a former age (94); and the furnishings of the chapel where they worship eloquently testify to the past (76).

But just as the narrator's sensitivity to passing time becomes visible in the life within St. Jürgen, so, too, does his joy at knowing that memory offers a possibility of overcoming this sensitivity. The inmates of the hospice, he tells us, can only look backward (77). They cannot and do not forget $(78,85) .{ }^{102}$ In their memories they still see the past (79) and know of the glories of old times (75).

Life in St. Jürgen also shows that the narrator has taken cognizance of the vanishing in time of the power of memory. The windows of St. Jürgen look out onto a cemetery bearing the same name as the hospice $(72,78) .{ }^{103}$ Indeed, the people of St. Jürgen live in the very shadow of the graves which, in time, will bury their memories with them.

The narrator is again aware of the shadow of death hovering over them and their memories when he speaks of the open coffins which stand in the corner (77); when he refers to the home as an 
abode for those awaiting death (72); and when he repeatedly tells of the occurrence of death in St. Jürgen $(72,77,111-113) .{ }^{104}$

VII. THE NARRATIVE'S LITERARY PROTOTYPE AND ITS TREATMENT OF THE JOY AND ANGUISH OF BEING BOTH ABLE AND UNABLE TO COPE WITH PASSING TIME

Following the custom of the first biography of Theodor Storm written by Paul Schütze, most discussions of In St. Jürgen have included a brief comparison of this Novelle with its literary prototype, Das Heimweh, a story published in Biernatzkis Volksbuch auf das Jahr 1849. Judging from what the authors of subsequent discussions say, we may infer that they have used Schütze's comparison ${ }^{\mathbf{1 0 5}}$ as the source for their remarks, for, like Schütze, they invariably refer to the prototype in order to point out changes made by Storm. ${ }^{106}$

The knowledge of these alterations, however, does not prevent us from noting a striking similarity between Storm's tale and its literary prototype - a similarity that helps to confirm our belief in the concurrent presence of the ability and inability to cope with passing time as the determining factor in the formation of In St. Jürgen's narrative pattern. We believe that Storm was attracted to the earlier tale because in it the rudiments of the same pattern that he was to form in In St. Jürgen were already visible.

The earlier story, we discover, also contains a collection of commemorative tales, in each of which their narrator's sensitivity to passing time is made apparent. ${ }^{107}$ For a young girl, sixteen years have passed since childhood (s. 106); ${ }^{108}$ for an old man, fifty-one years have passed (s. 110) ; and for an old woman, practically her entire life (s. 111).

Likewise, these tales suggest an ability to overcome such sensitivity through the medium of memory. In her memory, the young girl can relive her childhood, as the words which the narrator puts in her mouth make indisputably clear: an jeden Punkt fast 
knüpften sich Erinnerungen und mein Kindheitsleben wurde wieder in mir wach (s. 107). Similarly, in the old man's memory, the scenes and acquaintances associated with his youth lebten noch unverändert (s. 110). In the old woman's memory, the events of both the other tales are relived, even though manches Jahr seitdem dahin gezogen ist (s. 111).

All three tales also echo a realization on the part of the narrator that, after the passing of time, the power of memory will prove to be deceptive. The young girl soon loses sight of the places that once reawakened memories of her childhood (s. 107). The old man's nostalgia ceases its activity when, after it has compelled him to return to his native region, he is no longer able to find a single friend or relative alive (s. 110-111). As for the old woman's memory, we know it, too, faces extinction when the narrator has her indicate how aware she is of her approaching death due to advanced age (s. 111). 

EPILOGUE 



\title{
EPILOGUE
}

\author{
AQUIS SUBMERSUS AND IN ST. JÜRGEN \\ AND THE NARRATIVE FORM \\ OF THEODOR STORM'S OTHER TALES
}

What we found to hold true for Aquis submersus and In St. Jürgen is tenable as well for each and every one of Theodor Storm's other tales. It must be added, however, that sure and certain proof for this can only be had after each one of these Novellen has been subjected to a concrete form-analysis. This, however, is an area of Storm criticism in which a great deal of spade-work must yet be done. The overwhelming majority of these narratives - aside from the passing comment in larger, chiefly biographical studies has never been given any specific critical attention; and, except for the present study, none of the handwritten drafts of Storm's tales (see Appendix II) has ever been consulted for interpretative purposes. ${ }^{109}$

We can, therefore, offer only a preliminary confirmation of the presence in Storm's entire prose fiction of the same personal struggle that gives form to Aquis submersus and In St. Jürgen.

It is curious that, even though critics from Tempeltey (1867) to Martini (1962) $)^{110}$ have pointed out again and again how characteristic the theme of memory is in Storm's fiction, no one as yet has undertaken the task of making a typology of the individual commemorative structures in each of the author's Novellen. Such a 
typology would reveal tremendous differences in the commemorative structure of the various tales: In some stories the form is determined by the narration of a single commemorative situation; in others there are two, three, four, or even a larger number of recollections. Many of these recollections, moreover, contain other commemorative tales within them. There are therefore besides the numerical differences, two distinct types of recollections: framing exterior ones and framed interior ones. And just as is the case with exterior recollections, so, too, the number of the interior recollections differs greatly from tale to tale. Furthermore, many of these interior recollections function simultaneously as exterior frames to others contained within them.

Two conclusions would come to light through such a typology. The first is that the inherent fictional narrator who reappears in each of Storm's tales is constantly juggling a "remembered" past with a "remembering" present, a realization that the flow of time consumes what is past, together with a knowledge of an ability to retrieve the past in the present. The second conclusion, and the more telling, is that he constantly varies the relationship of the two conflicting thoughts he exhibits. Try as he may, therefore, he never seems able to resolve this frustrating dichotomy. He apparently can do nothing but endure its endless torment. ${ }^{111}$ 
NOTES 



\section{NOTES}

\section{INTRODUCTION}

1 See Wolfgang Kayser, "Die Anfänge des modernen Romans im 18. Jahrhundert und seine heutige Krise," Deutsche Vierteljahrsschrift für Literaturwissenschaft und Geistesgeschichte, XXVIII (1954), pp. 429-430, 439; "Das Problem des Erzählers im Roman," The German Quarterly, xxIx (1956), pp. 230, 236-237; “Wer erzählt den Roman?," Die Vortragsreise, Studien zur Literatur, Bern, 1958, pp. 91-92, 98; Victor Lange, "Erzählformen im Roman des Achtzehnten Jahrhunderts," Anglia, LXxvi (1958), pp. 130-135; Franz Stanzel, Die typischen Erzählsituationen im Roman, Wiener Beiträge zur Englischen Philologie, LXIII, Wien \& Stuttgart, 1955, p. 24; "Episches Praeteritum, erlebte Rede, historisches Praesens," Deutsche Vierteljahrsschrift für Literaturwissenschaft und Geistesgeschichte, XxxIII (1959); p. 11; Käte Hamburger, Die Logik der Dichtung, Stuttgart, 1957, p. 76; Margret Nientimp, "Zur Bedeutung der Erzählerfigur und der Erzählhaltung in Novellen des Realismus," Die Pädagogische Provinz, xIII (1959), p. 353; Dieter Stephan, Das Problem des novellistischen Rahmenzyklus, Untersuchungen zur Geschichte einer Darbietungsform von Goethe bis Keller, Diss. (typescript), Göttingen, 1960, p. 27. See, too, the very apt remarks on the narrator of Keller's Martin Salander by Margarete Merkel-Nipperdey, Gottfried Kellers 'Martin Salander,' (Palaestra 28), Göttingen, 1959, p. 14; and of his Kleider machen Leute by B. A. Rowley, (Studies in German Literature 2), London, 1960, pp. 12-21, esp. p. 15. See also the recent study by Volkmar Sander, "Zur Rolle des Erzählers in Mörikes Mozart-Novelle," The German Quarterly, xxxvI (1963), pp. $120 \mathrm{ff}$.

2 Even when a drama or a poem contains a narrator, e.g., Thornton 
Wilder: Our Town or T. S. Eliot: The Waste Land, he is never an omniscient observer who "relates" the entire drama or poem.

3 On integration in narrative fiction see Herman Meyer, "Zum Problem der epischen Integration," Trivium, vill (1950), pp. 299-318; "Von der Freiheit des Erzählers," Festgabe für L. L. Hammerich, Kopenhagen, 1962, pp. 181-190, esp. pp. 186ff. ; Eberhard Lämmert, Bauformen des Erzählens, Stuttgart, 1955.

4 See the way in which Paul Böckmann contrasts Ausdruckssprache with Sinnbildsprache in his Formgeschichte der deutschen Dichtung, I, Hamburg, 1949, esp. as summed up on pp. $691 \mathrm{ff}$. See also Richard Brinkmann's Wirklichkeit und Illusion, Tübingen, 1957. His main thesis is that the more "realistic" prose fiction in the nineteenth century appears to be, the more "subjective" it becomes (particularly applicable to the Novelle, as has been shown by Manfred Schunicht, "Der 'Falke' am 'Wendepunkt,'" Germanisch-Romanische Monatsschrift, N.F., X [1960], pp. $61 \mathrm{ff}$.). See also what Erich Kahler so happily terms Die Verinnerung des Erzählens - the title of three articles in Die Neue Rundschau, LXVIII (1957), pp. 501-546 \& LXX (1959), pp. 1-54, 177-220. See, too, what Victor Lange (op. cit., p. 144) equally happily terms die Verinnerlichung des Erzählens. See, furthermore, the numerous references to subjectivism throughout Fritz Martini's recent book, Deutsche Literatur im bürgerlichen Realismus, 1848-1898, Stuttgart, 2nd ed., 1964.

5 Albert Köster, the editor of the critical edition of Storm's works, went so far as to classify Aquis submersus as the author's supreme artistic achievement (Theodor Storms Sämtliche Werke, Leipzig, 1919-1924, I, pp. 50, 59); and the Russian novelist Ivan Turgenev, to mention a fellow artist's opinion, called it Storm's Meisterschuss (in an unpublished letter to the author, dated Dec. 8, 1876, now in the SchleswigHolsteinische Landesbibliothek). In St. Jürgen has also been praised very highly. See Erich Schmidt, Charakteristiken, 2nd ed., Berlin, 1902, 1st series, p. 410.

- Theodor Storm to Emil Kuh, Aug. 24, 1876, Theodor Storm Gedenkbuch, ed. by Friedrich Düsel, Braunschweig, 1917, p. 201.

' Thea Müller, Theodor Storms Erzählung: 'Aquis Submersus,' Marburg, 1925 , p. 72.

8 Albert Köster in his edition of Storm's works, op. cit., viII, p. 258; Franz Stuckert, "Der handschriftliche Nachlass Theodor Storms und seine Bedeutung für die Forschung," Schriften der Theodor-Storm-Gesellschaft, I (1952), p. 55. 
- The nine year old Katharina (267) has become a young lady in the meantime (269). According to the chronology of Ernst Feise, Xenion, Essays in the History of German Literature, Baltimore, 1950, p. 231, she is now sixteen. This would indicate seven years had passed.

10 In all previous discussions of Aquis submersus this particular reminiscence has been noticed only twice: by Ernst Feise when he states: Rückschauend gedenkt er seiner ersten Vakanz (op. cit., p. 228) and when he mentions the Rückblick auf erste Vakanz 1649 (op. cit., p. 230); and by Rudolf Buck when he says: In kurzen Rückblicken überfliegt er die Vorgeschichte ("Theodor Storm: 'Aquis submersus,'” Der Deutschunterricht, 1953, Heft I, p. 97). Buck also makes an attempt at interpreting it. According to him, this recollection of past joyful scenes reflects the Optimismus der Jugend, i.e., of the character in the act of remembering, which stands in marked contrast to the dangers represented by the Gegner im Hintergrund. We would question whether this is the real reason for the recollection being inserted into the narration. We should imagine that the mere mention of the young man happily wandering along the countryside in spring, as he does, would have sufficed to contrast with a scene of unsuspected danger if, indeed, this had been the narrator's desire. Would it have been necessary in addition to refer in detail to a recollection of the past?

11 For a detailed treatment of the use of spatial descriptions as a means of vivifying the portrayal of time in nineteenth-century fiction, see the discussion by Herman Meyer: "Raum und Zeit in Wilhelm Raabes Erzählkunst," Deutsche Vierteljahrsschrift für Literaturwissenschaft und Geistesgeschichte, xxvir (1953), pp. 236-267. See also Günther Müller, "Aufbauformen des Romans," Neophilologus, xxxvir (1953), p. 11.

12 See Ernst Feise's excellent observation concerning the harsh vowel $u$ in Wulf (op. cit., p. 233). His reference to Wulfs Worte (p. 232, line 1), however, should read instead: Kurts Worte; on the other hand, the mention of Kurt, ihren Nachfahren (p. 234, line 34) should read: Wulf, ihren Nachfahren.

13 See Rudolf Buck, op. cit., p. 97, where attention is drawn to the double meaning of this statement.

14 See Günther Müller, "Erzählzeit und erzählte Zeit," Festschrift Paul Kluckhohn und Hermann Schneider, Tübingen, 1948, pp. 195-212; also the numerous other articles by the same author treating this topic.

15 See also the way the narrator makes the revolving movement of the clock visible by having his character walk around in a circle, killing time until a certain hour is at hand: Ich weiss nicht mehr, wohin mich 
damals meine Füsse noch getragen haben; ich weiss nur, dass ich in einem Kreis gegangen bin; denn da die Sonne fast zur Mittagshöhe war... (325).

18 The idea of one morning passing after the other is emphasized again by the image of the painter walking, morning after morning, across the heath $(316,322,331)$.

17 See also the detail that the narrator employs in order to impress upon his listeners how individual days gradually, but surely, pass: $A m$ andern Morgen (beginning of first day) the painter leaves for Hamburg; he arrives there abends bei guter Zeit (end of first day); am andern Vormittage (beginning of second day) he tends to business; um Mittage he starts on his return trip; and Am Nachmittage danach he arrives in Preetz; Es war schon spät am Nachmittage when he continues on his way and rides into the aufsteigende Dämmerung; when he returns home it is Mitternacht (end of second day); later he hears that die Hähne krähten and notices that der Morgen dammerte (beginning of third day); nach gevaumer Zeit he is out in the open country; and Nach ein paar Stunden his drawing is finished; he then hears das Mittagläuten and subsequently realizes: Es war schon lang, dass es geläutet hatte (288-302).

18 Here again the detail reveals how much the narrator wishes to stress the passing of time in the artist's life. The rapid change is made visible by referring to Cantate Sunday in May (265); the time of the year when the tulips were just breaking through the earth (278) and the rye on the fields had wavy green tops (266); the subsequent season when the rye started to bloom and the roses burst into flower (285); midsummer (288) and June (290); an event many weeks later (305); the time when the tree-tops began to show their autumn tints (306); the falling of the last leaves of autumn (306); the first snow of winter (308); Christmas (307); the New Year (309); the end of winter (307); and early spring (308).

19 Robert Pitrou, La Vie et l'Oeuvve de Theodor Storm, Paris, 1920, p. 524, also seems to be well aware that the narrator is trying to make the passing of time apparent with these dates. See the excellent way in which he mentions the year 1661 in the story: L' horloge $d u$ temps marque donc 1661. Subsequently, p. 525, he refers to cinq ans qu'il s'en est allé.

20 See also other references to the act of painting that indicate a time progression: Nach ein paar Stunden war die Zeichnung fertig (302); nach einiger Zeit [waren] diese Bilder ... nahezu vollendet (320); Es war schon spät. Mein Bild war fertig (334). 
21 See also the astute observation of Ernst Feise, op. cit., p. 237: Ja selbst bis in die Absatzanfänge klingt das Lied von der Zeit.

22 The inner tension expressed by these words also becomes apparent when they are compared with their more factual and much less personal counterpart written below the picture that stimulated Storm to write the tale: incuria servi. See Storm's letter to Paul Heyse, June 20, 1876, in Der Briefwechsel zwischen Paul Heyse und Theodor Storm, ed. by Georg J. Plotke, München, 1917, I, p. 125.

23 The tone of Fritz Böhme's commentary (Storms Werke, Leipzig, n.d. [1936], vili, p. 103) also stresses the emotional tension emanating from this scene: Das furchtbare Leid ... wird ... bis zur Grenze des Erträglichen gesteigert. The effort that the narrator makes to emphasize the painter's emotional reactions in this scene has been pointed out by the Russian novelist Ivan Turgenev in his Nov. 25 and Dec. 28, 1876, and Feb. 4, 1877, letters to Ludwig Pietsch. See Iwan Turgenjew an Ludwig Pietsch, Briefe aus den Jahren 1864-1883, ed. by Alfred Doren, Berlin, n.d. [1923], pp. 134, 137, 138; see also Arthur Luther, "Russischer Brief," Das literarische Echo, XII (1909), p. 281.

24 Squire Wulf jibes at him (282) and wishes to scare him with threats (284); he summons two savage curs to spring at his throat (294) and to hunt him like a wild beast (295); he subsequently flashes murderous eyes at him (303), wounds him (305), and makes it known that the dogs would be set on him again (310). Squire Kurt, the other enemy, first makes his animosity felt by exchanging a distant bow with him (284), and later gives the painter a glance that is like the point of a dagger (285); he looks surlily at him (293), fights him as a mortal enemy (294), and finally responds to the painter's act of humiliation and supplications with an air that is full of contempt and scorn (310). Bas' Ursel, the third adversary, first reveals a suspicious attitude towards him by not wanting to let him out of her sight (282), then disrupts his happiness (288); later she terrifies him (299) with a threatening hand (300), and finally betrays him (303).

25 He deludes himself into thinking that the eyes of an hostile ancestress are fixed at him $(281,286,287)$ and are looking at him out of his own child's eyes (333); he imagines himself being haunted by her ghost (300); and his disturbed senses trick him into hearing a voice that is not audible (332) and into seeing a person who is not visible (333). See also the reference to the état d'hallucination in Robert Pitrou, op. cit., p. 530.

26 Katharina is so overcome with emotion that she turns deathly pale 
and cries passionately (327), wails mournfully (328), and is so shocked that she shrieks (329) and even faints (335). The pastor uplifts his hands as if in pain, and tears run copiously down his face (334). The emotions of the brother, the third character in whom the artist's feelings are mirrored, are so overwrought that he imagines his heart is being cut (322); his body is so shaken because of this, we are told, that he has to take to bed (330).

27 Storm in a letter to Emil Kuh, Aug. 24, 1876, said that the witch burning constituted a Seiten- oder Hintergrund (Storm Gedenkbuch, op. cit., p. 200). By that he means, we believe, that it mirrors the emotional tension in the main character, inasmuch as it shows how the emotions of a whole town (322) and an entire village (323) of people become excited, and inasmuch as it inflames, as Therese Rockenbach states (Theodor Storms Chroniknovellen, Braunschweig, 1916, p. 78), the Gemütsstimmung of the reader. In view of this use of the witch burning in the narrative design, one is prompted to question the assertion of several critics that it mars the tale's artistry (Thea Müller, op. cit., pp. 45, 81, 98; Therese Rockenbach, loc. cit.; Storm Gedenkbuch, op. cit., p. 199).

28 See the statements with which the narrator reminds us of this: Was Junker Kurt ... entgegnete, ist mir nicht mehr erinnerlich (285); Was wir gesprochen, wüsste ich kaum zu sagen (285); Wohl weiss ich noch (299); Ich weiss nicht mehr, wohin mich damals ... ich weiss nur ... (325); Das ... Gärtlein ist mir unvergessen (325); Was dermalen selber ich gesprochen, ist mir schier vergessen; aber des Predigers Worte gruben sich in mein Gedächtniss (330); ich werde ihn leblang in den Ohren haben (329).

29 The disappearance of the once recollected joy occurred between $A$ nno 1661 (265) and Anno 1666 (311). According to the chronology of Ernst Feise (op. cit., p. 231), the artist was then between 23 and 27 years old. When the narrator refers to him recollecting the above, however, he is described as an old man, as Rudolf Buck (op. cit., p. 94) puts it, ein gealterter Mensch.

It follows from what we have just said that we cannot adhere to the assumption of Feise (loc. cit.) that this subsequent memory, as we might call it, does not constitute a single recording of the past, but rather represents two different ones written 35 years apart: in 1665 when the artist was still a young man and in 1700 when he was old. If these dates were correct, it would mean that only part of the story of the vanished recollected joy (311-335) is being recalled subsequent to the time it had vanished, the other part (265-310) having been 
recalled beforehand in 1665. But this is not the case. The first part, just like the second, was written after 1700 , when the artist was an old man (the unpublished conclusion, see Appendix I, pp. 108-109, gives the dates $1701,1706,1709)$. Such statements in the first part as: itzt hier ... die theuerste Gesellschaft meines Alters (281) and wenn du, mein Gott, mich bald nun rufen lässt aus diesem Erdenthal (296) make this quite clear. They do not differ at all from similar statements in the second part revealing the memorialist to be an old man: ich ... anitzt als alter Mann (312), Mir aber soll er eine Mahnung sein, ehbevor auch an meiner Uhr der Weiser stille steht ... Denn $d u$... der du nun bald mein Erbe sein wirst ... (311). Further proof may be found in the narrator's reference in the first part to: all Glück und Leid und auch all nagende Busse meines Lebens (267), and Rosen auf; doch itzt, wo alles klar und auch alles vergangen ist, weiss ich es wohl, wir hätten beide die Zeit gerne stille stehen lassen (the version of 285, lines 17-19, in Storm's first handwritten draft). These things could only have been said by the artist at the end of his life (see Feise's footnote, loc. cit.). Similarly, the painter's assertion at the end of the first part (310) that he is temporarily laying his pen aside to attend the christening of his sister's grandchild lets the listeners know he is recording this as an old man. Since he had only one sister (320) and was older than she (320 \& Feise, loc. cit.), he certainly must have been an old man at the time of her grandchild's christening.

30 How intentionally Storm wished this limitation of the recollection to be a part of the narrative form may be seen from the fact that, in the final draft of the Novelle, he crossed out everything the artist remembers about his life subsequent to the cessation of the joy. In the first and second handwritten drafts, the recollection did not end with the termination of the joy (see Appendix I).

31 It has often been noticed that this technique, commonly referred to as the sprunghafte Verfahrensweise, is quite typical of Storm's art. For the most detailed treatment of the subject see Hannelore Faden, Die Physiognomie des Erzählers bei Storm, Diss. (typescript), Frankfurta.M., 1954, pp. 48-91. See also the recent discussion by Karl Ernst Laage, "Das Erinnerungsmotiv in Theodor Storms Novellistik," Schriften der Theodor-Storm-Gesellschaft, vir (1958), p. 22.

32 See such expressions as: ich mag es heut wohl niederschreiben (285); das soll nicht hier verzeichnet werden (309); Aber ich will vors erste nun die Feder ruhen lassen (310); Mir aber soll er eine Mahnung sein ... mit der Aufzeichnung meines Lebens fortzufahren (311); die ersten Blätter 
dieser Niederschrift (319). See also Thea Müller's statement: Was in diesen alten Blättern steht, ist Evinnerung (op. cit., p. 78), and her reference to the manuscript as an Evinnerungs-Handschrift (p. 79).

s3 Thea Müller, op. cit., p. 7, states that the handwriting has also faded (vergilbte Blätter mit verblassten Schriftzügen). We can find no evidence for this, however, in the text of the narrative.

84 Previous critics of Aquis submersus have frequently taken cognizance of this proverb and, by so doing, have underlined its importance for the narrative. But, strangely, they have never observed that it is always incorporated into the narrative with particular reference to the memoir. See Rudolf Buck, op. cit., p. 94; Ernst Feise, op. cit., pp. 227, 237; Thea Müller, op. cit., pp. 21, 55, 80; Robert Pitrou, op. cit., p. 527; Therese Rockenbach, op. cit., p. 25; Franz Stuckert, Theodor Storm, Sein Leben und seine Welt, Bremen, 1955, p. 336.

s5 The only other explanation that has been offered for the presence in the narrative of two copybooks instead of one was made by Hans Bracher, Rahmenerzählung und Verwandtes bei G. Keller, C. F. Meyer und Th. Storm, Untersuchungen zur neueren Sprach- und Literaturgeschichte, N.F., III, Leipzig, 1909, p. 67. It is quite different, however, from ours: Die Manuskriptfiktion ... kann der Technik auch retardievende und damit spannungswirkende Elemente liefern. Wenn der Fortgang einer Erzählung plötzlich unterbrochen wird mit der Erklärung: 'Hier schliesst das erste Heft der Handschrift' und die Handlung einige Seiten später wieder regelvecht weitergeführt wird, so kann das nur retardierend gemeint sein. Although this may be true, we hardly think it suffices as a reason for why Storm decided to use two copybooks. Why should he have gone to all the trouble to describe two copybooks when he could have retarded the flow of the narrative much more easily by interrupting it with occasional interjections referring to a subsequent age? And why, if he had really wished to retard the flow of the narrative, should he have resorted to two copybooks, which could effect such a retarding only twice?

36 A reference in the first handwritten draft of the narrative to the painting of the boy (a variation of 334 , lines $29 \mathrm{f}$. of the printed version) helps to make this especially vivid: er ... betrachtete bald die kleine Leiche und bald das Bild, das bald allein noch übrig sein sollte.

87 In Storm's handwritten drafts this picture is referred to as an Oelbild instead of a Schilderei. The knowledge of the change in the printed version helps to make the picture's function as a reminder even more obvious.

38 See J. J. de Gelder, Bartholomeus van der Helst, Rotterdam, 1921, esp. 
pp. 157-253. It is interesting to note that in the first handwritten draft of the narrative, in a variation of 265 , lines $6 \mathrm{f}$. of the printed version, we are told that van der Helst gave the artist a small painting as a parting gift. This may well have been a portrait of van der Helst which could serve as a reminder of him.

39 See Harry Schmidt, Jürgen Ovens, Sein Leben und seine Werke, Kiel, n.d. [1922], esp. pp. 137-221, 234-255, 258-262.

40 See the statement of Thea Müller, op. cit., p. 102: Im Augenblick ... erscheint dem Maler das Bild der Geliebten plötzlich als das lebende Original. Rudolf Buck, op. cit., p. 100, says: zugleich hat es [das Bild] sie festgehalten. Johannes Klein, Geschichte der deutschen Novelle von Goethe bis zur Gegenwart, 4th ed., Wiesbaden, 1960, p. 281, tells us the viewer begegnet Katharina nicht nur vergeblich wieder: er sieht sie noch einmal in ihrer Jugendschönheit, im Bildnis...

41 Thea Müller, loc. cit., remarks very aptly concerning this painting: Auch konkrete Erscheinungen werden öfters beseelt: am eindrucksvollsten das Bild der Ahne, das lebendig gedacht wird und quälend wie ein böser Mensch. Rudolf Buck, loc. cit., speaks of the animosity being bildhaft gegenwätig. Johannes Klein, op. cit., p. 280, says: er [der Zuschauer] erschrak vor dem Bild einer Ahnin. And on p. 281 the same author states: das Grausame [nimmt] Gestalt an: im Bild jener Ahnin.

12 A comparison of Storm's first draft with the final version of the narrative makes us more sensitive to this. In the former we are told that the portrait hangs in a corner behind a press, on top of which lies the memoir (im Winkel hinter einem Schranke), the implication being that the man in the painting is watching over the memoir from a distance. In the final version, however, we are given to understand that the portrait hangs more definitely within the shadow of the press (im Schatten eines Schrankes). The two are thus connected by the shadow, and the vigilant eye in the painting is more specifically attentive to the other object within the shadow's orbit.

43 See also Thea Müller's description of the room's deathly stillness: Man hat sofort das Gefühl, dass hier die Zeit stillsteht, in diesem Raum, wo das alte Bild von der Wand schaut, wo aus der offenen Lade der Moderduft des alten Papiers steigt, wo der bequeme Ohrenstuhl geradezu einlädt zu ruhigem Verweilen (op. cit., p. 79).

44 See another observation, which is to be found in the second draft of the narrative: ... so wird hier fortan auch Katharinas Bild stumm von der Wand herabschauen ... trotz meiner Kunst, ein Schatten - weiter nichts! Mich fröstelte... (variation of 286, lines $14 \mathrm{ff}$.). See also the tale 
Viola tricolor, where the word Schatten is again employed in reference to the fading portrait of a woman whose image had appeared to be eternized by a painting (Werke, ed. by Albert Köster, III, p. 288).

45 E. O. Wooley, Studies in Theodor Storm, Indiana University Publications, Humanities Series No. 10, Bloomington, Indiana, 1943, p. 62.

46 See Walter Silz, Realism and Reality: Studies in the German Novelle of Poetic Realism, University of North Carolina Studies in the Germanic Languages and Literatures No. 11, Chapel Hill, North Carolina, 1954, p. 130; Willy Schumann, The Technique of Characterization in the late Novellas of Theodor Storm, Diss. (typescript), Columbia, 1959, pp. 7182; Richard M. Meyer, Die Deutsche Literatur des 19. und 20. Jahrhunderts, 6th ed., Berlin, 1921, p. 336; J. Vlasimsky, "Mimische Studien zu Th. Storm," Euphorion, xvir (1910), pp. 643ff. \& XVIII (1911), pp. $150 \mathrm{ff}$.

47 It might be mentioned in this connection that the words aquis submersus are echoed five times in the narrative $(257,261,334,335,336)$. See Herbert Seidler, Allgemeine Stilistik, 2nd ed., Göttingen, 1963, p. 144.

48 Thea Müller, op. cit., p. 64.

49 See Thea Müller, op. cit., pp. 41, 42, 64; Robert Pitrou, op. cit., p. 523; Paul Schütze, Theodor Storm, Sein Leben und seine Dichtung, 4th ed., Berlin, 1925, p. 267; Gertrud Storm, Theodor Storm, Ein Bild seines Lebens, Berlin, 1912-1913, II, p. 175; and the notes by Albert Köster in his edition of Storm's Werke, viII, p. 259.

50 The silver color, as Ernst Feise, op. cit., p. 236, has pointed out, shows that the sea trügerisch wie lichtes Silber glänt.

51 A reading of the handwritten drafts helps to make the narrator's intentions more obvious. In the first draft his fear concerning the fate of this portrait is expressed twice in even stronger terms. On one occasion he tells his audience of his belief that his fear has become a reality: Katharinens schönem Jugendbilde ... habe ich vergebens nachgeforscht; vermuthlich ist es ganz vernichtet (see Appendix I, p. 111). In another version he even goes so far as to describe very vividly the way in which the painting disappeared and disintegrated: Auch Ks schönem Jugendbilde ... habe ich vergebens nachgespürt ... aber niemand wusste davon; endlich fand sich eine uralte Frau ... Diese erinnerte freilich ein Bild, wie ich es ihr beschrieb, derzeit auf dem Kirchenboden wohl gesehen zu haben, aber es seien von den Ratten grosse Löcher darin gewesen; endlich bei ein Reparatur des Daches sei es fortgeschafft $u$. des Predigers Kinder hätten sich aus der bemalten Leinewand ein Zelt gemacht (see Appendix I, pp. 112-113). 
52 Although the connection between the two paintings has frequently been pointed out (Hans Bracher, op. cit., pp. 53, 122; Rudolf Buck, op. cit., p. 101; Thea Müller, op. cit., p. 77; Therese Rockenbach, op. cit., p. 76), the only previous attempt at interpreting the meaning of this relationship is the rather generalized and not very telling explanation by Hans Bracher and Thea Müller that a Spannungswirkung results.

53 A comparison of the narrative's three versions serves to make us more aware of this double effort. We come to realize that this desperate attempt to curb his own feelings was quite intentionally, and step by step, incorporated into the narrative, a fact that, we believe, underlines its function in the form-giving pattern of Aquis submersus.

In the first draft of the narrative, for instance, we are merely told of the two pictures side by side and of a viewer's interest in them. In the second draft, however, we are not only told of the pictures and of his interest in them but also why he observes them so closely: Immer wieder zog es mich zu diesen beiden Bildern, denn auch das des priesterlichen Mannes ... erregte in mir ein phantastisches Verlangen, von ihm und seinem Knaben eine ... Kunde zu erhalten (variation of 260 , lines 28-31). The addition is significant, for now the impression is given that the portraits hanging side by side are used as supports for one another, and the viewer naturally believes that they will mutually shed light on each other. We are thus made to see that the reason for mentioning these two pictures in the narrative is to make us aware of an attempt on the part of the narrator to overcome his doubts about the permanency of pictorial recollections by assuring himself that an auxiliary painting is there to help recall the story should one of the pictures eventually fail to do so.

Turning to the third version of the narrative, we become conscious of an intensification of this attempt. The impression that one painting supports another is retained, but this no longer applies to both paintings. We are only told about the viewer turning to the clergyman's portrait in order to learn more about the boy. Since the latter constitutes the subject of the primary auxiliary portrait, the emphasis is now placed on the primary auxiliary painting itself being aided by another painting. It is not, therefore, just the mere endeavor to have one painting help another that is given poetic expression here, but rather the more specific attempt to safeguard the original commemorative portrait with a double-strength reinforcement: an auxiliary painting that is, in turn, safeguarded by a secondary auxiliary painting. 
We are also made aware of the narrator's intention by another difference in the versions of the narrative. In the first draft we are told that there is a whole series of pictures hanging together: Im Schiff der Kirche nemlich hing eine Reihe meist schlecht gemalter Brustbilder alter Prediger. Unter all diesen... (variation of 260, lines 13-14). In the later versions this sentence was deleted. The narrator starts with Unter all diesen... and then goes on to describe only the two pictures (260). The change was made, we believe, in order to show more clearly that it is not the pictures in the church that are of interest, but rather the double-strength reinforcement represented by the two specific paintings.

54 Here again a comparison of the handwritten drafts proves to be revealing. In the first draft the audience is told about only one painting bolstering the Ovens painting. This, however, was intentionally changed, as Storm's second draft shows, into the double reinforcement about which we are told in the printed version. That this particular double reinforcement was quite intentionally inserted into the narrative design indicates, we think, how thoroughly the audience is supposed to be made cognizant of the use of paintings as a means of sustaining the memories incorporated in other portraits.

s5 The somewhat different wording of Storm's first draft makes more apparent the way in which the narrator intends the complete understanding of the portrait to be contingent upon the reading of the memoir: Hier endete die Handschrift. - Sinnend wandte ich m. Augen nach dem alten Bilde, das mir gegenüber hing; nun wusste ich freilich jetzt, wen es vorstellte und verstand gar wohl wie es damit gemeint gewesen war (see Appendix I, p. 111).

It should be noticed that the sentence: Hoffen wir, dass der Schreiber ein fröhliches Tauffest gefeiert und inmitten seiner Freundschaft an frischer Gegenwart sein Herz erquickt habe, which, in the final draft, is inserted between the references to the memoir and the painting and which, moreover, visibly separates them from one another (310-311), is missing in the above. Thus, in the first draft, the comprehension of the portrait's identity more immediately follows the reading of the memoir and is more closely dependent upon it.

sB We find this impression confirmed by three different critics: by Hans Bracher, op. cit., p. 64, when he says: Dieses zweite Rätsel [wer jener tote Knabe war] ... wird im zweiten Heft entschleiert; by Robert Pitrou, op. cit., p. 527, when he asks: qui est l'enfant? and then replies: La seconde partie de la narration va y répondre; by Therese Rockenbach, op. 
cit., p. 77, when she too asks who the boy was and subsequently states: Die Antwort auf diese sinnende Frage gibt das zweite Heft der Handschrift.

57 For confirmations of this statement see the reference of Ernst Feise, op. cit., p. 227, to die Frage nach Bild und Inschrift und endlich die Auffindung des Manuskripts, das uns der Lösung näher bringt; see also the reference by Thea Müller, op. cit., p. 77, to die geheimnisvollen Buchstaben, der ungenügende Versuch, sie zu enträtseln followed by her statement: und nun gibt uns der Dichter [we would say: Evzähler] den Schlüssel in die Hand in Gestalt der alten, vergilbten Aufzeichnungen; see, furthermore, Robert Pitrou's pourquoi 'aquis submersus'? [in reference to the $A$.S. of the picture's inscription] and his answer: $L a$ seconde partie de la narration va y répondre (op. cit., p. 527).

58 Rudolf Buck, op. cit., p. 93, has made us aware of this eisiges Schweigen, as he calls it.

59 Ernst Feise, loc. cit.

60 See Storm's letter to Paul Heyse, June 20, 1876, in Der Briefwechsel zwischen Paul Heyse und Theodor Storm, op. cit., I, p. 126.

61 See the somewhat different way in which Rudolf Buck, op. cit., p. 94, interprets this landscape as being emblematic of the death that is wrought by passing time. He regards it as something that continues to exist after the people who had lived there have passed on. This, he says, makes for a contrast between the permanency of the setting and the passing of human life, a contrast which makes the reader all the more sensitive to the latter.

62 The significance of this dark corner is underlined by our knowing that Storm was apparently particularly conscious of it, as the change from the schattige Ecke in the first handwritten draft to the dunkle Ecke of the subsequent versions reveals.

63 Apparently, Storm wants us to be very much aware of the narrator's doubts about popular tradition as a permanent commemorative support, for in each subsequent version of the narrative the fragmentary nature of the popular tradition receives an additional stress. In the first draft the only occasion the audience is informed of the inability of popular tradition to keep the facts of the past together is when the narrator mentions that the meaning of the inscription remains unknown to those who later personify popular tradition. In the second draft, however, we are told in addition that the painter's name, how he had been banished to the village, and where he had come from, had been lost as popular tradition had been passed on. In the third, printed version, this scepticism receives a still further stress through a 
deletion. A sentence contained in the second draft is taken out: Aber im Dorfe war, abgesehen von jener Sage, sein Andenken längst verschollen. This sentence reveals the strength of popular tradition as a commemorative medium, since it is the only thing in the village that continues to keep the memory of a certain person alive. This intentional omission in the third version makes the inability of popular tradition to recall the past, which had been stressed more in the second version than the first, stand out even further.

64 Frederic E. Coenen, "Problems in Theodor Storm's Novellen," The Germanic Review, xv (1940), p. 42.

65 Robert Pitrou, op. cit., p. 524, in speaking of this memory refers to a double 'Einkleidung,' a particularly appropriate expression, for it does much to evoke a picture of one preserving memory (or set of commemorative media, as we should say) being preserved by another.

o6 See the excellent observation that Ernst Feise, op. cit., p. 226, makes concerning the role of this personal memory: Immer zieht Storm den Stoff in sein Ich hinein, formt ihn aus rückschauender Erinnerung und legt so über das furchtbare Geschehen den lindernden Schleier der Zeit, der diesem Geschehen ... die Härte des grellen Lichtes nimmt... Zumal der Rahmen dient diesem Zweck ... vielleicht am kunstvollsten in seiner Meistererzählung 'Aquis submersus.' Although Feise does not state what in particular the antecedent of das furchtbare Geschehen is, he has, nevertheless, comprehended admirably the memory's soothing function within the narrative. The only exception we would take to his observation is to his reference to Storm remembering. Since it is in the narrative itself that the soothing feeling is discovered, then the person who remembers, the incarnation of this feeling, must also be an inherent part of the narrative. Storm, the author, however, is not. $\mathrm{He}$ was separated from Aquis submersus at the moment it became an autonomous work of fiction.

Like Feise, and also quite correctly, Therese Rockenbach, op. cit., p. 74, states: ...die Form der Erinnerungsnovelle [trägt] dazu bei, über die oft tragischen Eveignisse einen mildernden und versöhnenden Schleier auszubreiten. But it is just because of this function of the memory that we cannot agree with another statement by the same author to the effect that this particular act of remembering merely constitutes an introduction to the Novelle. 'Aquis submersus,' she says, schildert im einführenden Rahmenteil die Auffindung alter Manuskripte; deren Inhalt bildet die eigentliche Novelle (p. 74). Such a statement carries with it the implication that this act of remembering is not an integral part 
of the Novelle - something that we think it irrefutably to be. Why, one is prompted to ask, should a Novelle need an introduction? Does not a genuine work of art speak for itself?

A similar underestimation of the poetic significance of memory within the narrative is the interpretation that Franz Stuckert, op. cit., p. 335 , offers. Gerade wegen des düsteren Inhaltes der Erzählung, he states, ist eine so heitere, breitflächige Einleitung gewählt. Again we are told that this act of remembering is an introduction to the narrative. Again we are given to understand that it does not constitute an integral part of the fictional entity we call Aquis submersus. Nevertheless, according to Stuckert, it does have its functions. It furnishes, he says, a heitere and breitflächige counterpart to the narrative. This somewhat puzzles us, for we cannot see what is heiter or breitflächig about it, nor does Stuckert elucidate.

Another function, Stuckert tells us, is the author's intention to make the relationship between narrator and audience closer. By having scenes and events of the past remembered in the first person by someone in the present, Stuckert argues, the narrator brings the past into the present and thus more closely associates himself with his audience. To use Stuckert's own words: ...denn an sich entspricht der Bau der Rahmenhandlung vollkommen dem, was Storm seit jeher bei der Einführung seiner Novellen geübt hatte. Er hatte schon immer den persönlichen Einsatz bevorzugt, um jene Intimität zwischen Erzähler und $Z u$ hörer zu schaffen, die ihm von der mündlichen Erzählung her höchstes Bedürfnis war. Darum holt er ... den Stoff durch ein teilweise recht kompliziertes Verfahren unmittelbar an sich heran und gewinnt aus dem Gegensatz zwischen dem Einst und dem Jetzt eine besonders eindringliche Wirkung. But what, we should like to ask, does a closer relationship between narrator and audience signify? What relevance does it have for the aesthetic form of Aquis submersus? And why, if the author had wanted to do this, should he have resorted to the technique of a complicated framework involving a past and a present? Could not the narrator have associated himself with his audience much more easily by simply telling a story about a present familiar to them?

No less an oversimplification of the importance of the memory under discussion is the function that Thea Müller, op. cit., p. 77, attributes to it. Der Anfang der Rahmen-Erzählung, she says, vertritt die vollständig auf spannende Wirkung berechnete Aufgabe der Exposition. Such an interpretation reduces the importance of memory to a mere technical device and completely overlooks its symbolic nature. 
67 Against this thesis one might argue that, as far as the second of the two discoveries is concerned, the narrator not only shows how the possessor of the all-embracing memory becomes aware of the fate awaiting personal memory but, in addition, how he recalls the memory of the old woman and, thus, recaptures it from the oblivion that befell it at her death. And since the joy inherent in such a recapturing would override any depression over time's oblivion, one could then say that the dominant note of the experience is positive rather than negative. Consequently, there would be no reason to assume that the narrator is disturbed over the fate of the old woman's memory or to believe that he thinks of it as a paradigm of the fate of the all-embracing memory. The reply to this is that the narrator describes the meeting of the possessor of the all-embracing memory with the old woman and the ensuing recapturing of her memory as entirely too much a chance happening for us to conclude that it could render negligible his disquietude; such an accidental occurrence cannot be considered something that would repeat itself a generation later when, in turn, the possessor of the all-embracing memory will have become old. Conversely, however, the realization on the narrator's part that the recapturing is most likely limited to this single occurrence might easily serve to aggravate his perturbation.

68 See Hans Bracher's descriptions of the two principal types of frames used around German Novellen in the nineteenth century (op. cit., pp. 69-70). One of these he characterizes as ein 'unvollständiger' oder 'offener' [Rahmen], d.h. es besteht, as he goes on to say, wohl die Fiktion einer in der Gegenwart oder doch in einer dem Leser näherliegenden Zeit evzählenden Person; aber diese im Leser geweckte Vorstellung eines Erzählers tritt [nicht] ... am Schlusse der Gesamtgeschichte noch einmal hervor. Es ist also ein Anfangsstück, aber kein Schlußstück des Rahmens vorhanden. The other type of frame, according to Bracher, ist 'vollständig, geschlossen.' Der Schluss der Evzählung nimmt die Anfangsfiktion wieder auf. Der Leser wird in die Zeitvorstellung zurückgeführt, in die ihn der Anfang versetzt hatte. Diese Form erscheint am häufigsten. Sie ist die echte oder eigentliche Rahmenform im Gegensatz zu der ersteren, der unechten.

69 Originally, in the first draft of the narrative, Storm conceived the frame to be a closed one. Both the possessor of the all-embracing memory and the identical setting depicted at the beginning and during the interruption of the narration of the other memories reappear at the end. 
In the second draft practically everything mentioned at the conclusion of the preceding draft, including the possessor of the all-embracing memory and the nature of the setting, is eliminated. Because of this, the closed frame of the first draft appears in the second version only in a very blurred form. The only detail in this new conclusion that retains the idea of a closed frame is the reference to the fact, as at the beginning and during the intermission, that someone is reading the manuscript.

In the third, printed version even this is dropped. Another conclusion is substituted, which does not relate at all to the frame mentioned at the beginning and during the intermission. No mention is made of any of the events or persons referred to in the earlier parts of the frame, and we now have a frame intentionally changed from the closed type to an open-ended one.

70 It is interesting to note that the above is written on the reverse side of the manuscript page on which the opening part of the frame is described. This helps to confirm our opinion that the passage was intended to be the concluding part of an enclosing frame.

71 The conscious attempt to express the evanescence felt by the poets of the Baroque is emphasized when, as a note to the printer in Storm's second draft instructs, the opening word of these verses begins with a verziertes Initial. That Storm had the poets of the Baroque in mind at the time he wrote Aquis submersus becomes apparent also from the references to Opitz and Grimmelshausen in his letter to Wilhelm Petersen, July 13, 1876, in Theodor Storm, Briefe an seine Freunde, ed. by Gertrud Storm, Braunschweig, 1917, p. 128. Strangely enough, none of the many studies concerned with Storm's ideas about death and immortality, with his Christian or non-Christian thinking, has taken into account his interest in the literature of the seventeenth century.

72 Both Hans Bracher, op. cit., p. 65, and Therese Rockenbach, op. cit., p. 78, refer appropriately to a Resignationsschluss and a Resignationsstimmung respectively.

\section{Part Two: IN ST. JURGEN}

73 Quoted by Gertrud Storm from the unpublished and, as far as we have been able to ascertain, now lost diary of the author (G. Storm, op. cit., II, p. 204). See E. K. Bennett \& H. M. Waidson, $A$ History of the German 'Novelle,' 2nd ed., Cambridge, 1961, p. 171.

74 loc. cit. 
75 See other specific references to the passing of years: viele Jahre (73, 110), viele Jahre später (75), mehreve Jahre später (95), In all den Jahren (108), all die Jahre hindurch (87), ein paar Jahre lang (76), noch ein Jahr (107), In den ersten Jahren $(104,107)$, der letzten Jahre (106), die letzten zehn Jahre (94), nach anderthalb Jahren (103), noch neun Jahre (93), nach achtzehn Jahren (87), vor ïber vievzig Jahren $(96,97)$, vor nun bald fünfzig Jahren (97), Um fünfzig Jahre (113), seit Jahrhunderten $(77,97)$, in früheren Jahren (76), jährlich (77), nach zweijähriger Wanderung (79).

${ }^{76}$ Further examples are: Am andern Morgen $(90,99), A m$ andern Tage (84, 93), Am letzten Tage (98), in den letzten Tagen $(83,84)$, In den letzten Monaten (80), Einige Monate nach... (106), später im Jahr (109), der letzte Strahl der Vormittagssonne (94), Mittag werden (94), in den vergehenden Tagesschein (109), einen ganzen Abend ... zugebracht (80).

77 Robert M. Browning, "Association and Disassociation in Storm's Novellen: A Study on the Meaning of the Frame," PMLA, Lxvi (1951), p.392.

${ }^{78}$ Other indefinite words and expressions referring to passing time that the narrator employs, usually repeatedly, are:endlich, damals, damalig, später, zu spät, plötzlich, bald, bald darauf, kurz darauf, gleich darauf, einst, einstens, eine Weile, ein Weilchen, allmählich, inzwischen, längst, oftmals, oft und ofter, derzeit, derzeitig, früher, seit früh, seitdem, nachdem, nach einem kurzen Schweigen, nach einiger Zeit, nach kurzer Zeit, seit jener Zeit, vergangene Zeit, während der ganzen Zeit, in nächster Zeit, eine Zeitlang, jetzt endlich Zeit, stundenlang, eine halbe Stunde lang, jene Stunde, nächste Stunde, fast eine Stunde, manche Stunde, die Stunde kam, ein Stündchen früher, morgen, gestern, vergangen, Vergangenheit.

79 According to Fritz Böhme, op. cit., Ix, pp. 250-251, the portrait of the clergyman (76) has the likeness of a reformer. If Böhme is correct, this reference also echoes the narrator's awareness of the passing of historic eras. The same holds true for the Stegreifjunker episode (76), an event which, according to Böhme (p. 251), took place in 1587.

80 The latter dates, implied by the reference to the Schwedenzeit (86), have been ascertained by Fritz Böhme, loc. cit.

$81 C f$. the quite different interpretation of the reference to the wizard practices put forth by Franz Stuckert, op. cit., p. 296. He says they are portrayed unfavorably in order to show that they represent deviations from the traditional norms of bourgeois society that confine Storm's characters.

82 Franz Stuckert, op. cit., pp. 294-295; Georg Baesecke, Review of Hans Eichentopf: Theodor Storms Erzählungskunst in ihrer Entwicklung, in Zeitschrift für deutsche Philologie, XII (1909), p. 529; Fritz Böhme, op. 
cit., virl, p. 59; Anne Theobald, The Theme of Isolation in the Novellen of Theodor Storm and Ferdinand von Saar, Diss. (typescript), London, 1959 , p. 98.

83 In accordance with what he has said in regard to In St. Jürgen, Georg Baesecke, loc. cit., interprets the analogous situation in Immensee negatively. Franz Stuckert, op. cit., pp. 244-245, on the other hand, sees it in a positive light, something which, when confronted with his In St. Jürgen comments, seems paradoxical to us. Neither Baesecke nor Stuckert observes the portrayal of the same phenomenon in Hans und Heinz Kirch (see Benno von Wiese, Die deutsche Novelle von Goethe bis Kafka, II, Düsseldorf, 1962, p. 232).

84 See Robert M. Browning, op. cit., p. 391.

85 Franz Stuckert, op. cit., p. 296, amplifies upon this by saying: Vor allem Agnes lebt völlig in und mit dieser Vergangenheit, und wenn sie von sich selber sagt: 'Ich kann nur schwer vergessen', so bezeichnet sie mit diesem persönlichen Charakterzug zugleich das Wesen der traditionsgebundenen Gemeinschaft, der sie angehört.

86 When Franz Stuckert, loc. cit., speaks of the old hospice as a bildgewordene Chronik, he, too, seems to realize that it constitutes a daily reminder of the past.

87 Robert M. Browning, op. cit., p. 392, in commenting upon this statement says quite appropriately: "the heroine Agnes Hansen well knows why she must tell her story, just as Johannes in Aquis submersus knows why he must tell his... Not to be forgotten... - that makes a tremendous difference to the people we meet in Storm."

88 Robert M. Browning, loc. cit.

89 Franz Stuckert, op. cit., pp. 295-296, makes this very clear when he says: Jeder ... evzählt einen Teil der Geschichte ... und beide Teile schliessen sich zu einem geschlossenen Ganzen zusammen. Diese doppelseitige Einheit wird besonders dort als kunstvolle Fügung deutlich, wo beide denselben Vorgang von ihrem Standpunkt aus berichten; was der eine ... verschweigt, das sagt der andere. See also Robert Pitrou, op. cit., p. 420, who refers to a double récit, la narration de Harre venant se superposer à celle de sa fiancée, en la continuant... (Et en la complétant sur certains points, p. ex. la scène des adieux, discrètement écourtée par le récit d'Agnès - footnote to above).

90 The two halves of the story that the old man and woman represent are further accentuated by their diametrically opposite geographical residences: southern Swabia (95) and northern Husum (72 ff.). In comparing In St. Jürgen with its literary prototype, Das Heimweh, previous 
critics do not seem to have taken into account the fact that Storm changed, quite meaningfully, the old man's setting from Dresden in the earlier story to Swabia in the later one. Robert Pitrou, op. cit., p. 421, even erroneously states that the old man of Storm's Novelle settled in Dresden just as did his counterpart in Das Heimweh.

91 See the perspicacious observation of Karl Ernst Laage, op. cit., p. 26: Theodor Storm liebt es, die Vergangenheit in einer Novelle von mehreven Seiten her aufzuhellen. So umfasst z.B. die Novelle 'In St. Jürgen' zwei getrennte Erinnerungserzählungen, die der alten Agnes Hansen sowie die des Tischlermeisters Harre Jensen, und diese beiden Erinnerungserzählungen werden ihrerseits wieder von einem Rahmen eigener Jugenderinnerung umspannt. Robert Pitrou, op. cit., p. 420, appropriately speaks of the Ich-Erzähler as the garant de l'unité du récit. Less clear, but nevertheless worth mentioning, is a statement by Fritz Lockemann (Gestalt und Wandlungen der deutschen Novelle, München, 1957, p. 162): Der Erzähler [Lockemann means our "mature man," not "the narrator"], der an dem Geschehen nicht selbst beteiligt ist, vernimmt die aus überschauendem Rückblick gegebenen Erzählungen der beiden Helden, der Agnes und des Harre.

92 For references to the swallows as the chorus of In St. Jürgen, see Franz Stuckert, op. cit., p. 296; Fritz Böhme, op. cit., viII, p. 284; Erich Schmidt, op. cit., p. 410; Rolf Lenhartz, Die lyrische Einlage bei Theodor Storm, Diss., Bonn, 1931, p. 84.

93 Printed in The Canadian Monthly, II (1872), pp. 323-344. Unfortunately, Storm's letter to Erich Schmidt of June 26, 1880, in which he comments on this translation, is in the hands of Schmidt's heirs (estate of the late Professor Werner Richter, Bonn), who apparently will neither let it be examined nor give out any information. At any rate, attempts to obtain information by both the late Franz Stuckert and myself have not been successful. According to Robert Pitrou, op. cit., p. 421, who had access to the letter fifty years ago, Storm mentions in it the change of title. It would be interesting to know what his reaction was.

94 See the observation of Robert Pitrou, op. cit., p. 420: Quand Agnes avait pris congé de son fiancé en lui recommandant: 'N'oublie pas de revenir!', l'hirondelle qui était posée près d'eux s'était envolée. See also the reference of Johannes Klein, op. cit., p. 271, to: wie ... die heimgekehrte Schwalbe nach Agnes' Worten, Harre solle das Wiedersehen nicht vergessen, davonfliegt und vorweg genommen wird, 'dass' er nicht wiederkommen wird. Rolf Lenhartz, op. cit., p. 85, observes: Beide wissen, was die Schwalbe ihnen sagen will: wir sehen uns nicht wieder. 
95 Robert Pitrou, op. cit., p. 421, states very aptly: ...les hirondelles dessinent leurs arabesques autour du clô̂tre et saluent de leurs appels la jeunesse entuie, le passé qui n'a pu revivre.

96 Paul Böckmann advises me of the generally unknown fact that it was due to a preoccupation with Rückert's swallow song that Detlev von Liliencron wrote his Schwalbensiciliane. Since Liliencron, as his poem An Theodor Storm reveals, was well acquainted with Storm's works, it would indeed be interesting to find out to what extent his Schwalbensiciliane was also influenced by Storm's use of Rückert's song. A study of the development and changes in the use of the swallow chorus from poet to poet, Rückert - Storm - Liliencron, should likewise prove to be enlightening; it would constitute an excellent way of mirroring the history of literary form in nineteenth-century German literature.

97 Robert M. Browning, op. cit., p. 391, says: "the swallows' song awakens preteritive concepts."

98 Rolf Lenhartz, loc. cit., tells us: Jede Schwalbe erinnert Agnes an Harre, der ihr das Wiederkommen versprochen hatte.

99 Rolf Lenhartz, loc. cit., states: die Gedanken Harres sind wie die Schwalben um den Turm der Kirche immer um Agnes. Johannes Klein, loc. cit., speaks appropriately of the Erinnerung durch die Schwalben in Schwaben.

100 Johannes Klein, loc. cit., also speaks of a symbolic significance in the swallows' spring arrival and autumnal departure, but interprets this as a reference to the happiness and disappointment in the characters' lives, rather than as a means of echoing the narrator's feelings about time and memory.

101 Franz Stuckert, loc. cit., also emphasizes the fact that the narrative's setting is the St. Jürgen hospice since, in his opinion, it constitutes a Spiegel des alten ehrbaren Bürgertums, das sich ganz auf Sitte und 'Reputation' gründet. One wonders whether the real significance of the hospice lies in its mirroring the ideals of bourgeois society and whether Stuckert is not taking the statement of one of the hospice's inmates (77) as representative of the entire institution. The other of the two inmates whom we meet in the story, the Spökenkieker, does not typify any of these ideals. We are told that he does not possess a good reputation (77), that he has led a foolish and sinful life (77), that he has been a rascal (83), a broken-down peddler (83), and a man who has profited at the expense of the credulous (83). It should also be noted that he outlives the other inmate. At the end of the narrative he is still in the hospice, whereas his bourgeois counterpart is dead (111-112). That the depiction of this institution does not specifically signify an 
intent on the part of the narrator to make the bourgeois world visible is supported by another of Storm's tales. In Ein Doppelgänger we learn that even a beggar has lived in St. Jürgen's hospice (Werke, ed. by Albert Köster, viI, pp. 172, 193).

102 We refer again to Franz Stuckert, loc. cit., who says: wenn sie [Agnes] von sich selber sagt: 'Ich kann nur schwer vergessen', so bezeichnet sie mit diesem persönlichen Charakterzug zugleich das Wesen der traditionsgebundenen Gemeinschaft, der sie angehört.

103 The detailed description of the hospice has also been noticed by Hans Bracher, op. cit., p. 93. He stresses, however, its technical rather than its symbolic function, for he speaks of it as a means devised by the author to prepare for the introduction of one of the characters.

104 Our interpretation of the use of the hospice of St. Jürgen as an aesthetic element to localize the narrative pattern can be further substantiated by referring to life in the hospice as it is portrayed in another tale, Bötjer Basch. The passing of time becomes manifest when we are told that an inmate advances in age from seventy to almost ninety (Werke, ed. by Albert Köster, vII, pp. 74, 97). We are also told that the inmate constantly keeps memories of another person alive (op. cit., pp. 97, 101, 102). Just as in In St. Jürgen, the hospice borders upon a cemetery (op. cit., pp. 73, 97); thus, the inmates live in the shadow of the graves which, in time, will bury their memories with them. The occurrence of death in the hospice (op. cit., pp. 74, 102) also emphasizes the institution's role in showing that the stream of time will eventually engulf memory.

105 Paul Schütze, Theodor Storm, Sein Leben und seine Dichtung, 1st ed., Berlin, 1887, pp. 181-186.

108 Fritz Böhme, op. cit., vilI, p. 57; Wolfgang Kayser, Bürgerlichkeit und Stammestum in Theodor Storms Novellendichtung, Berlin, 1938, pp. 3637; Robert Pitrou, op. cit., pp. 418-421; Erich Schmidt, op. cit., pp. 410-411; Franz Stuckert, op. cit., pp. 293-294. Somewhat of an exception is the study by Rudolf Thietz: "Erleben und Gestalten bei Theodor Storm," Dithmarschen, II (1922), pp. 122-124, 144-147. He seems to have compared In St. Jürgen with its literary prototype without relying on Schütze, for his analyses are far the most detailed. Nevertheless, the purpose of his study remains essentially the same as Schütze's.

107 Somewhat misleading is Robert Pitrou's statement: $A u$ vécit unique de Biernatzki, Storm substitue un double récit (op. cit., p. 420). This conveys the impression that in the structures of Das Heimweh and In St. Jürgen 
there are but one and two tales respectively, which is not the case. 108 The letter "s" followed by a numeral denotes s(ource): Das Heimweh and the page in Biernatzkis Volksbuch auf das Jahr 1849 where the particular reference may be found. I quote from a rare copy of this book in the Schleswig-Holsteinische Landesbibliothek in Kiel.

\section{EPILOGUE}

109 How imperative it is for the critic of Storm to consult the author's manuscripts has also been brought to light by J. W. Smeed in his essay, "Theodor Storm and His Reading Public: Some Cases of Editorial Interference and its Effect," Durham University Journal, LII (1960), pp. 125-128. Smeed cites convincing evidence for the belief that many passages in Storm's tales are the products of editorial censorship and, therefore, constitute elements foreign to the artistic composition.

110 Ed. Tempeltey, Th. Storms Dichtungen, Kiel, 1867, p. 10; Fritz Martini, op. cit., pp. 630-631.

111 The narrator's torment, which would come to light with a typology of Storm's prose narratives, prompts us to offer an afterthought to Herman Meyer's very stimulating essay, "Von der Freiheit des Erzählers," Festgabe für L. L. Hammerich, Kopenhagen, 1962, pp. 181190. Meyer states (p. 187): So ist die Erforschung der [Evzähler-] Perspektive dazu angetan, uns zur Liberalität im Geltenlassen mehrever [Erzähl-] Möglichkeiten und dadurch zu typologischem Verständnis [der Erzählkunst] zu erziehen. We would add: So ist die Evforschung der Typologie der Erzählkunst dazu angetan, uns zum Verständnis der Erzählerperspektive zu erziehen. 

APPENDIX I 



\section{APPENDIX I}

The author's drafts of a conclusion to Aquis submersus, hitherto believed to be lost

\section{Prefatory note}

Since our interpretation of the form of this narrative is in many instances based upon individual passages of the following texts, they are printed here in full. The reader can thus ascertain the context of all references to them in the body of the essay.

Attention is once again drawn to the fact that no attempt has been made to emend or alter in any way Storm's orthography. Words between brackets indicate internal cancellations of the author.

\section{The texts}

The following paragraph appears to be the beginning of the author's first draft of a conclusion. The same sign that can be seen on the top of the unnumbered page on which it is written can be found on the bottom of the last, also unnumbered page of the text which it concludes: 
Nach einem kurzen Zusatz enthält dic Handschrift. Die Züge sind noch unsicherer geworden. Der Schreiber steht bereits im Greisenalter.

Anno 1665 am ersten Dienstag des Oktobermondes sah ich Katharina zum letzten Mal auf dieser Erde; nach fast 36 Jahren gestern am achten desselbigen Monats 1701 ist sie entschlafen. Ihr Ehemann der Prediger hat es mir angezeiget; die einigste Botschaft, so ich von dort erhalten habe. Aber auch diese harte Hand-ich sehe es-zittert itzt.

The above is crossed out. Apparently, Storm wished to start the conclusion anew:

Nach einem kurzen Zusatz enthält die Handschrift: Während aber in dem Vorstehenden ein längst Vergangenes berichtet wird, so ist dagegen diese letzte Aufzeichnung der unmittelbaren Gegenwart entnommen, in welcher - die noch unsicherer gewordenen Schriftzüge bezeugen es - der Schreiber bereits die Schwelle des Greisenalters überschritten hat.

A large space and a highly decorative initial letter " $A$ " indicate that the following, although a continuation of the above, refers to a different period:

Am Vormittage d. 13 Octobris dieses laufenden Jahres 1709 war es, oft machte ich meinen täglichen Spaziergang in dem Lustgarten des Schlosses, welches seit dem Ableben der Hochsel. Herzogin Maria Elisabeth in allen seinen Theilen dem Publico geöffnet steht. Das Ziel meines Ganges aber war auch dieses Mal die kleine Anhöhe oberhalb des Fischteiches. Wer sonst dahin geht, ergötzet sich an dem lichten Grün der Marschen und dahinter an der Silberfluth des [Meeres]Wassers, auf welcher das Schattenspiel der Insel schwimmt, 
[meine Augen aber blickten nordwärts über die Haide] ich aber pflegte dorthin zu gehen, um meine Liebe zu besuchen. [Denn sie lebte noch auf Erden.] Zwar zu [einander konnten wir nicht kommen] mir kam sie nicht; [weit über ein Menschenleben war es, dass wir uns nicht gesehen hatten;] aber meine Augen, die noch in weite Ferne blicken können, sahen dann über die Haide nordwärts nach dem [spitzen] grauen Kirchthurm, der dort aus dem öden Lande aufsteigt. In jenem Dorfe, [das zu seinem Fusse] wo vor länger als einem Menschem [leben] alter ich sie zum letzten Mal gesehen, [war] lebte sie auch noch heute, [ohne Kinder] in einer kinderlosen Ehe, [neben jenem Manne] deren Band gleichwohl so feste Erdendauer haben sollte.

Sonst wousste ich nichts von ihr; aber seit meines lieben Bruders Tode, wo ich hieher zurückkehrte, in all den fünfzehn Jahren ist kaum ein Tag

Although the above is not crossed out, the following, written toward the bottom of the same page, seems to indicate that Storm wished to rewrite the last part:

[Gestern am ersten] Vor nun vierzig Jahren am ersten dieses jetzigen Monats sah ich K. zum letzten Mal auf dieser Erde; gestern am 3 Octobris dieses laufenden Jahres 1706 ist sie entschlafen. Es trieb mich etwas, dass ich in den Schlossgarten gehen musste, welchen [ich sei] mein Fuss nicht betreten hat in all [èn] den Jahren, die ich seit meines lieben Bruders Tode hier [mich dauernd] gehauset habe. Ich ging nach der Anhöhe oberhalb des Fischteiches; mir war als zoürde ich dahingetragen. Und als ich, wie ich nicht wohl anders konnte, über die Haide hin nach Norden blickte, sah ich den Thurm des fernen Dorfes flimmend in der Morgensonne ragen. Aber auf einmal sahe ich ihn nicht mehr; es war nur leere Luft wo er gestanden; und doch reichen meine Augen noch in weite Ferne; [und] 
auch wurde der Thurm nach einer Weile wieder sichtbar; es war gleich einem Nebel der vorbeigezogen

Auch vor meinen Ohren sang es wie aus Wogenschwalle: A.S.! O Herr so nimm die Seelen in Deine treue gnadevolle Hut.

\title{
Amen
}

The following lines are spaced apart from the above text and seem to represent an attempt, quickly given up, to add an afterthought to the above:

[In dieser] War es der Nebel des Todes, der vorüberschwamm, oder wurde meine Seele von einer anderen fortgezogen, dass sie die Dinge dieser Erde nicht gewahren konnte, -

Separated from these two texts are the following verses, which constitute, it would seem, a different continuation of the paragraph that ended with the Amen:

\author{
Die Lilien u. die Rosen \\ So mit d. Weste kosen, - \\ Das schöne Theil der Erden, \\ Des Leibes edle Zier, zunichte \\ Muss es werden \\ Und geht als Staub herfür.
}

Another attempt to write a conclusion to the narrative is revealed in the following lines. They are written on the side of the page on which all of the above is to be found and seem to indicate that Storm was dissatisfied with everything he had previously written and wished to begin completely afresh:

Dessen Herr Johannes sich einstens gegen den Junker Wulf ermessen, dass er's wohl auch cinmal in seiner Kunst den Grösseren gleich zu 
thun verhoffe, das sollten Worte bleiben in die leere Luft gesprochen. [Vielleicht] Wenn Katharina damals, als sie noch beide jung waren, mit ihrem Knaben zugleich gestorben wäre, vielleicht, dass er es dann gewonnen hätte; denn die schwarze Erde hat geheimnisvolle Heilkraft. So - da sie lebte, konnte er nicht zu seiner Kunst gesunden. Sein Name wird nicht genannt, ja selbst in seiner engeren Heimath weiss niemand von einem Maler seines Namens. Sein 'Lazarus' [ist] der nur noch in der Chronik unserer Stadt Erwähnung findet, ist [beim] nach dem Abbruch der alten Kirche zu Ende des vorigen Jhs mit ihren anderen Kunstschätzen verschleudert worden, der Himmel weiss, wohin. Katharinens schönem Jugendbilde, [habe ist] das er selber für sein Meisterstück erkannte habe ich vergebens nachgeforscht; vermuthlich ist es ganz vernichtet. Denn in jenem Dorfe

On another unnumbered page we find once more a fresh attempt to write a conclusion:

Armen lag d. todte Kind

Hier endete die Handschrift. - [Ich blickte] Sinnend [blickte ich] wandte ich m. Augen nach dem alten Bilde, das mir gegenüber hing; [ich] nun wusste ich freilich jetzt, wen es vorstellte und verstand gar wohl wie es damit gemeint gewesen war. Herr Gerhardus [sah] blickte so mild [auf mich] herab, [als zähle er nun auch mich zu seinen Freunden] in Grossvaters Arme [n] geborgen schlummerte das Kind mit sciner stillen Blume.

Aber noch einmal wie wohl vergebens durchsuchte ich dann die Blätter der kl. Lade (denn noch viele Fragen drängten auf mich ein.Wann nach seines Bruders Abscheiden war Herr Johannes [zum] andre Male in die Stadt gekommen? Und wann-wann hatte $K$ 's Leben aufgehört? War ihr [schöner] süsser Leib, 'der Erde schönes 
Theil,' wie der alte Dichter Opitz sagt, - schon früh dem Staub zurückgegeben? - Ich glaube kaum.

Dessen Herr Johannes sich einstens (im Vollgefühl seiner Kraft) gegen den Junker Wulf vermessen, dass er's wohl auch einmal in s. Kunst den Grösseren gleich zu thun verhoffe, das sollten Worte bleiben in die leere Luft gesprochen. Wäre [K. gleich ihrem Knabcn] ihm nach allem Leid das Erdenglück geworden, noch in der Jugend K's Grab zu sehen, dann meine ich-nach der dürftigen Spur seines Lebens zu urtheilen-hätte er [es] wohl gewin?en [mögen] müssen; denn die Kirchhofserde hat geheimnisvolle Heilkraft. Nur, wenn sie lebte, konnte or nicht zu seiner Kunst gesunden. Aber s. Name wird nicht genannt, kaum dürfte er in einem Künstler-lexicon zu finden sein; ja selbst in seiner engeren Heimath weiss niemand von einem Maler [seines] dieses Namens. [Von] Seines grossen Lazarus-Bild [giebt] thut zwar die Chronik unsrer Stadt Erwähnung. Das Bild selbst aber ist zu Anfang dieses Jahrhunderts nach dem Abbruch unsercr alten Kirche wie andere. Kunstschätze derselben verchleudert worden $u$. verschwunden.

Auch Ks schönem Jugendbilde, das er selber für s. Meisterstück crkannte, habe ich vergebens nachgespürt. Schon in den nächsten Tagen ging ich auf das Dorf hinaus und besuchte den jungen fremden Pastor, der in einem neuen Hause wohnte. Ich fand hohe wohltapezirte Zimmer, [schöne Kupferstiche] statt der kl. Almanachsbilder hingen schöne Kupferstiche nach Raphael u. Overbeck an den Wänden; nach [Norden] Süden u. Osten statt früher nach Nord u. Westen lagen die Wohnzimmer; cs war alles anders. Aber die jungen Pastorsleute[n] waren freundlich [wie] gleich den dahingegangen Freunden meiner Jugend.

Ich erzählte von meiner Handschrift, wir besuchten zusammen die Kirche in der die alte Zeit geblieben war; wir schlugen dann die 
Kirchenbücher nach, aber die Nachrichten derselben reichten nicht in jene Zeit hinab. Vor allem zurde dem schönen Bilde nachgeforscht, das urkundlich jener Handschrift in dem alten Pastorate einst gewesen; aber niemand wusste davon; endlich [bei einem zweiten Besuch] fand sich eine uralte Frau, welche [bei] einst in ihrer Jugend bei dem Vorgänger von meines Freundes Vater in Dienst gestanden hatte. Diese erinnerte freilich ein Bild, wie ich es ihr beschrieb, derzeit auf dem Kirchenboden wohl gesehen zu haben, aber es seien von den Ratten grosse Löcher darin gewesen; endlich bei ein Reparatur des Daches sei es fortgeschafft u. des Predigers Kinder hätten sich aus der bemalten Leinewand ein Zelt gemacht. 'Wer' - so schloss die Greisin ihren halb unwillig abgestatteten Bericht - regardirt auf solch alte Familienportraiten, wenn die Freundschaft ausgestorben ist!'

Und das war alles. Aquis submersus.

The words Aquis submersus seem to have been inserted subsequently, probably after Storm had crossed out these lines, which immediately follow the sentence: Und das war alles.

Meiner Neugierde [des Knaben] hatte die Vergangenheit mit reicher Kunde geantwortet; jetzt, da ich für jene längst Gewesenen in eine fast leidenschaftliche Theilnahme hineingerissen worden, schwieg sie hartnäckig. - Bei meiner Rückkehr nach der Stadt, vermied ich die viel kürzern Gassen und ging die verlassenc Landstrasse, die einstens Herr Johannes u. [die auch ich] als Knabe auch ich selber noch gegangen war. Als ich langsam über die Haide schritt, welche der [ringsum] urbarmachende Pflug noch übrig gelassen hatte, hörte auch ich nach Westen hinab das Tosen der Meeresbrandung und auch in meinen Ohren scholl es ein ewiger nicht endenwollender Gesang, Aquis Submersus! 
Und dann nichts weiter. Aus der Tiefe der Vergangenheit keine Spiegelung mehr herauf.

In the second draft of the entire narrative we find a new attempt to write a conclusion:

Noch einen kurzen Zusatz enthält die Handschrift; während aber im $V$ orstehenden eine schon weit dahinten liegende Vergangenheit berichtet wird, ist dagegen diese letzte Aufzeichnung der unmittelbaren Gegenwart entnommen, [in welcher] Schon die noch unsicherer gewordenen Schriftzüge bezeugen es. - Der Schreiber bereits die Schwelle des Greisenalters überschritten hat. Sie beginnt mit einem $V$ ers, der nach der Weise des Martin Opitz klingt, vielleicht [indessen] aber unseren Herrn Johannes selber zum Verfasser haben mag.

(etwas Raum zu lassen, dann verziertes Initial)

Die Lilien und die Rosen,

So mit dem Weste kosen;

Das schöne Theyl der Erden

Des Leibes edle Zier -

Zunichte muss es werden

Und geht als Staub herfür.

All of the above in the second draft is crossed out, and once more another conclusion follows. It is identical with the one in the printed text. 
APPENDIX II 



\section{A PPENDIX II}

A list of the various extant manuscripts of Theodor Storm's narrative prose, together with a note about the author's unpublished correspondence

\section{Prefatory note}

The following list is for the benefit of those critics who, when interpreting Storm's fiction, will want to consult his handwritten drafts. There exist only two other listings of these manuscripts. One is given by Albert Köster in his Prolegomena zu einer Ausgabe der Werke Theodor Storms (Berichte über die Verhandlungen der Sächsischen Gesellschaft der Wissenschaften zu Leipzig, Philologisch-historische Klasse, Lxx), Leipzig, 1918, pp. 5-14. This listing is completely out of date and of little use today. The other has been made by Franz Stuckert, "Der handschriftliche Nachlass Storms und seine Bedeutung für die Forschung," Schriften der Theodor-Storm-Gesellschaft, I (1952), p. 55. This list is often in error, for many manuscripts that are said to be in the Schleswig-Holsteinische Landesbibliothek in Kiel or in the Goethe- und SchillerArchiv in Weimar cannot be found in either of these libraries. There is no record that they ever were in Kiel or Weimar. Other manuscripts, on the other hand, which Stuckert thought to be 
wholly or partially lost, are in one of these two repositories. Our list, therefore, differs considerably from the one that he has published.

All of these manuscripts are invaluable for any form-analysis since the alterations and changes made by both the author and his editors (sometimes without his consent) are exceedingly numerous. The only attempts to reco-d these deviations from the printed text were undertaken by (1) Albert Köster in Volume viII of the edition of Storm's works cited in our study, and by (2) Robert Pitrou, Le Travail de 'Polissage' dans les Nouvelles de Th. Storm, Documents pouvant servir à l'étude de la langue et du style Stormiens, Caen, 1920. Both of these, however, list but a few of the many changes.

\section{Theodor Storm's manuscripts}

1. Hinzelmeier (fragmentary) Schleswig-Holsteinische Landesbibliothek

2. Auf dem Staatshof

3. Drüben am Markt

4. Veronika

5. Im Schloss

6. Auf der Universität

$\begin{array}{ll}", & " \\ " & "\end{array}$

Part of this manuscript was believed lost (Köster, Prolegomena ..., p. 7 ; Stuckert, loc. cit.). It was, I discovered, contained in the folder of Auf dem Staatshof.

7. Unter dem Tannenbaum

8. Abseits

(fragmentary) Nissen Haus, Husum

9. Die Regentrude

10. Bulemanns Haus

11. Von Jenseit des Meeres

12. Eine Malerarbeit

13. Eine Halligfahrt

14. Draussen im Heidedorf

15. Zerstreute Kapitel (part)

16.

17. Beim Vetter Christian (part)

18

19. Viola tricolor (fragmentary)

20. Pole Poppenspäler

21. Waldwinkel

22. Ein stiller Musikant

23. Psyche

24. Im Nachbarhause links

Schleswig-Holsteinische Landesbibliothek " "

Goethe- und Schiller-Archiv, Weimar

Goethe- und Schiller-Archiv, Weimar
Schleswig-Holsteinische Landesbibliothek

Goethe- und Schiller-Archiv, Weimar

Schleswig-Holsteinische Landesbibliothek

Goethe- und Schiller-Archiv, Weimar

Goethe- und Schiller-Archiv, Weimar
Schleswig-Holsteinische Landesbibliothek

Nissen Haus, Husum

Schleswig-Holsteinische Landesbibliothek

Nissen Haus, Husum

Schleswig-Holsteinische Landesbibliothek

Part of this manuscript was believed lost (Köster, Prolegomena ..., p. 11;

Stuckert, loc. cit.). It was, I discovered, contained in the folder of $A$ uf $\mathbf{d e r}$ Universität.

25. Aquis submersus (1st draft)

26.

27. Carsten Curator (2nd draft)

Schleswig-Holsteinische Landesbibliothek

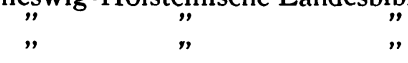


APPENDIX 11

28. Renate

29. Im Brawerhause (Der Finger)

30. Die Söhne des Senators

31. Der Herr Etatsrat

32. Hans und Heinz Kirch

33. Zur Chronik von Grieshuus

34.

35. 'Es waren zwei Königskinder'

36. John Riew' (f ragmentary)

37. Ein Fest auf Haderslevhuus

39. Bötjer Basch (part of 1st draft)

40. Ein Bekenntnis

41. Der Schimmelreiter

42. Die Armesünderglocke

43. Eine Sylter Novelle (fragmentary)

(fragmentary and hitherto unknown)
Schleswig-Holsteinische Landesbibliothek

" " " "

private possession of: Büchereidirektor Ewald Lüpke, Braunschweig, Fasanenstrasse 31

Nissen Haus, Husum

Schleswig-Holsteinische Landesbibliothek

"

$"$

Nissen Haus, Husum

Schleswig-Holsteinische Landesbibliothek
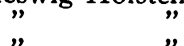

\section{Theodor Storm's unpublished correspondence}

In addition to listing extant manuscripts of Storm's tales, we should like to point out that there are many hundreds of autograph letters, shedding a great deal of light on Storm's prose, which have either not appeared at all in print or, if they have been published, have appeared in versions of questionable reliability. Particularly unreliable are the five volumes of correspondence edited by his daughter Gertrud Storm. These contain not only numerous inaccuracies, but also many omissions and changes that the editor has presumably made in order to convey a more favorable impression of her father. It likewise must be pointed out that the two volumes of correspondence with Paul Heyse, edited by Georg J. Plotke, are not free from omissions, some of which radically change the tone of the letters.

Most of Storm's letters can be found in the Schleswig-Holsteinische Landesbibliothek and in the Nissen Haus in Husum, but many other libraries and private collections also possess individual items. For 
APPENDIX II

various places housing the letters see (1) Wilhelm Frels, Deutschc Dichterhandschriften von 1400 bis 1900, Leipzig, 1934, pp. 290-291, (2) Franz Stukert, op. cit., pp. 56-60, and (3) Margaretha Koch, "Allerlei zerstreute Kleinigkeiten aus dem Nachlass Theodor Storms," Schriften der Theodor-Storm-Gesellschaft, xiv (1965), pp. 20-23. The listings of Frels and Stuckert are the most extensive. However, both of these scholars greatly underestimate the number of letters contained in the larger collections to which they refer. They also do not make mention of Storm's letters to his admirer Albert Niess, and to his friend the Russian novelist Ivan Turgenev, which are to be found respectively in the Stadtbibliothek, Braunschweig, and the Bibliothèque Nationale, Paris. 
APPENDIX III 



\section{APPENDIX III}

\section{THE RECENT CRITICISM OF THEODOR STORM}

Almost all of the contributions to criticism of Storm up to the early 1950 's are enumerated and, to a large extent, evaluated in the following three bibliographies:

Wooley, E. O., Studies in Theodor Storm, Indiana University Publications, Humanities Series 10, Bloomington, Indiana, 1943, pp. 106141.

Bernd, Clifford A., "Die gegenwärtige Theodor-Storm-Forschung, Eine Bibliographie," Schriften der Theodor-Storm-Gesellschaft, iii (1954), pp. 60-79.

Gebauer, Hannelore, "Beitrag zur Storm-Bibliographie," Schriften der Theodor-Storm-Gesellschaft, v (1956), pp. 60-71.

Of the more recent literature on Storm the following items should be the most helpful, or provocative, for critics who wish to amplify or modify our form-analyses:

\section{Critical surveys}

Goldammer, Peter, " $\mathrm{Zu}$ einigen neueren Publikationen über Theodor Storm," Weimarer Beiträge, 1958, pp. 557-566. A discussion of 
recent Storm criticism from a Marxist point of view. See his other article listed under Miscellaneous critical studies.

Martini, Fritz, "Deutsche Literatur in der Zeit des 'bürgerlichen Realismus,' Ein Literaturbericht," Dcutsche Vierteljahrsschrift für Literaturwissenschaft und Geistesgeschichte, xxxiv (1960), pp. 636640 ; also in Forschungsbericht zur deutschen Literatur in der Zeit des Realismus, Stuttgart, 1962, pp. 56-60. A very judicious account of recent books on Storm and the latest editions of his works.

\section{Studies concerned with individual narratives}

\section{a. Immensee}

Ulshöfer, Robert, "Epische Situation und symbolisches Ereignis in der Prosadichtung. Dargestellt an Storms Immensee," Der Deutschunterricht, 1956, Heft 3, pp. 37-45. A pedagogical essay whose critical value is largely due to its explanation of why Reinhard does not write to Elisabeth.

Andrews, John S., “Immensee and Victorian England," Modern Language Review, liv (1959), pp. 406-410. The author describes the reactions of a number of Victorian readers to individual scenes in Immensee, as well as to the narrative as a whole. These reactions pose questions that should be very welcome to anyone interested in interpreting the tale.

Wooley, E. O., "Immensee, Ein Beitrag zur Entstehung und Würdigung der Novelle," Schriften der Theodor-Storm-Gesellschaft, ix (1960), pp. 24-32. Useful because of its completeness in citing both the biographical experiences and the scenes in other novels that are echoed in the narrative. These point up similarities and dissimilarities that indicate peculiarities in Immensee's form.

McHaffie, M. A. \& Ritchie, J. M., "Bee's Lake, or the Curse of 
Silence, A Study of Theodor Storm's Immensce," German Life \& Letters, xvi (1962), pp. 36-48. Owing to its critical analysis of Immensee, scene by scene, and because of its stimulating comparison of the Novelle with Thomas Mann's Tonio Kröger, this essay is extremely valuable. But it invites a challenge when it states that the characters' "sense of loss is . . . not produced by the mere passing of time" (p. 41), and when it further claims that in the presentation of the story the omnipresent "remembering agent [is] generally omitted" (p. 43).

\section{b. In St. Jürgen}

Bernd, Clifford A., "The Pattern of Reminiscence in Storm's In St. Jürgen," The Germanic Review, xxxvi (1961), pp. 137-147. An earlier interpretation of our own that is somewhat different from the one offered in the preceding pages. Reprinted, in German translation, in Schriften der Theodor-Storm-Gesellschaft, xii (1963), pp. 27-37.

\section{c. Von Jenseit des Meeres}

Klamp, Gerhard, "Eine Schopenhauer-Reminiszenz bei Theodor Storm," Schopenhauer Jahrbuch, xxxviii (1957), pp. 159-161. The author attempts to show that Schopenhauer's aesthetic thought is echoed in the tale and, in so doing, opens up a new avenue of approach for critics of the narrative's form.

\section{d. Ein stiller Musikant}

De Cort, J., "Zwei arme Spielleute. Vergleich einer Novelle von F. Grillparzer und von Th. Storm," Revue des Langues Vivantes, $\mathbf{x x x}$ (1964), pp. 326-341. The author of this essay, by comparing two Novellen, points to striking characteristics of Ein stiller Musikant; conspicuously present among these characteristics is a consciousness of 
the devouring nature of the maw of passing time. In the critic's words: $V$ iel wäre hier noch zu bemerken zu dem für Storm so wichtigen Begriff der Zeitlichkeit. In Grillparzers Werk wird diese nicht stark betont. Gemeinsam ist für beide Novellen das Auftauchen eines beliebigen Helden, der dann zeiträumlich legitimiert wird und schliesslich in dem grossen Meer der Zeit wieder verschwindet (p. 340).

\section{e. Im Nachbarhause links}

Stinchcombe, J., "Theodor Storm's Im Nachbarhause links: An Appreciation," German Life \& Letters, xvi (1962), pp. 49-57. A very praiseworthy attempt to give critical attention to this neglected but excellent Novelle. Invaluable for all future discussions.

\section{f. Aquis submersus}

Steege, Victor, "Theodor Storm: Aquis submersus," Deutsche Novellen des 19. Jahrhunderts, Interpretationen zu Storm und Keller, ed. by Lothar Wittmann, Frankfurt a.M., 1961, pp. 17-49. An interpretation written for secondary school teachers in order to help them discuss the narrative more intelligently with their pupils.

Boll, Karl Friedrich, "Das Bonnixsche Epitaph in Drelsdorf und die Kirchenbilder in Theodor Storms Erzählung 'Aquis submersus,' " Schriften der Theodor-Storm-Gesellschaft, xiv (1965), pp. 24-39. This is the most detailed study that has been written on the genesis of the description of the paintings at the Novelle's beginning. Many inaccurate assertions of previous critics are corrected, but no attempt is made to explain the fictional significance of the paintings within the narrative composition. 
Wiese, Benno von, "Hans und Heinz Kirch," Die deutsche Novelle von Goethe bis Kafka, ii, Düsseldorf, 1962, pp. 216-235. This extremely lucidly written study merits particular attention because, like our own, it seeks to emphasize the role of the narrator. Unlike our interpretations, however, it does not make a distinction between "author" and "narrator."

\section{h. Der Doppelgänger}

Braun, Frank X., “Theodor Storm's Doppelgänger," The Germanic Review, xxxii (1957), pp. 267-272. An essay that deserves to be mentioned because of its judicious discussion of the tale's sociological aspects, which must be taken into consideration in any critical study of this narrative's form.

\section{i. Der Schimmelreiter}

Silz, Walter, "Theodor Storms Schimmelreiter," Schriften der Theodor-Storm-Gesellschaft, iv (1955), pp. 9-30. The German translation of a study (referred to in the Bernd bibliography, p. 77) that constitutes, unquestionably, the most subtle analysis of this Novelle that has ever been written. Invaluable for all future interpretations.

Busch, Andreas, "Neuer Beitrag zum Schauplatz der Schimmelreiternovelle," Die Heimat, lxvii (1960), pp. 302-305. Attempts to identify a number of real and imaginary objects described in the Novelle. The comparisons made are useful for the analysis of individual scenes.

Burchard, Annemarie, "Theodor Storms Schimmelreiter-Ein Mythos im Werden," Antaios, ii (1961), pp. 456-469. Contains excellent comments on the mythological elements that play an important formgiving role in the narrative.

Wittmann, Lothar, "Theodor Storm: Der Schimmelreiter," Deutsche Novellen des 19. Jahrhunderts, Interpretationen zu Storm und Keller, 
Frankfurt a.M., 1961, pp. 50-92. Critics of form will find this interpretation, written ostensibly for secondary school teachers, unusually suggestive. It is distinguished by close analysis and critical precision.

Loeb, Ernst, "Faust ohne Transzendenz: Theodor Storms Schimmelreiter," Studies in Germanic Languages and Literatures. In Memory of Fred O. Nolte, ed. by Erich Hofacker \& Liselotte Dieckmann, St. Louis, Missouri, pp. 121-132. A discussion of similarities, and differences, between Hauke Haien and the Faust of Part Two of Goethe's masterpiece. The essay is valuable inasmuch as it contributes to the deeper understanding of the Novelle's leading character. But its author invites criticism when he intimates that it is through the portrayal of a character, rather than through the composition of elements of aesthetic form, that we see the meaning of this Novelle. The following sentence of the author, in particular, conveys this impression: Hauke Haiens rationale Antwort an diese Mächte des Irrationalen, sein Versuch, sich und die Seinen abzuschirmen gegen die tragische Unentrinnbarkeit ihres Vordringens, sein Kampf und Unterliegen im Ringen um Lebenssinn und Selbstbehauptung: das ist der tiefste Sinn dieser Novelle (p. 126).

Hermand, Jost, "Hauke Haien. Kritik oder Ideal des gründerzeitlichen Übermenschen?" Wirkendes Wort, xv (1965), pp. 40-50. An investigation that shows how this Novelle is simultaneously idealistisch-heroisierend and realistisch-analytisch. Critics will want to read the author's penetrating analyses of the Novelle's central character and local color.

\section{j. Various Novellen}

Ubben, John H., "Theodor Storm und Gottfried von Strassburg," Schriften der Theodor-Storm-Gesellschaft, vi (1957), pp. 54-58. The German translation of a study (referred to in the Gebauer bibliography, p. 70) that calls attention to certain parallels, knowledge of which is useful for a close reading of Spätc Rosen and Ein Fest auf Haderslevhuus. 
De Cort, J., Forschungen zum Realismus des 19. Jahrhunderts in der deutschen Epik - Morphologische Interpretationen von 5 Novellen Theodor Storms, Diss. (typescript), University of Brussels, 1959. Analyses of Marthe und ihre Uhr, Im Schloss, Ein stiller Musikant, Renate, Hans und Heinz Kirch. Stresses the element of structure and thus extremely valuable from the standpoint of form-criticism.

Bernd, Clifford A., "Das Verhältnis von erlittenem und überwundenem Vergänglichkeitsgefühl in Theodor Storms Erzählhaltung," Schriften der Theodor-Storm-Gesellschaft, x (1961), pp. 32-38. A study that sketches the similarities and differences in the forms of Immensee, Aquis submersus, and Der Schimmelreiter.

Brech, Barbara Fuerst, Motive des Schweigens in Storms Novellen, Diss. (typescript), The Ohio State University, 1963. An investigation of the role that silence plays in Storm's works. Especially valuable for future analyses of Immensee and Der Schimmelreiter; invaluable for any study of the narrative Schweigen.

McCormick, E. Allen, Theodor Storm's Novellen. Essays in Literary Technique, University of North Carolina Studies in the Germanic Languages and Literatures No. 47, Chapel Hill, North Carolina, 1964. The author restricts his study to the treatment of isolated problems of literary technique and does not wish to put forth any single unifying thesis ; he concentrates on Storm's early productions and thereby tacitly disagrees with our opinion that the understanding of Storm's earlier, weaker narratives is contingent upon the understanding of the later, more developed masterpieces (see pp. 57-58 of our study). In his first chapter he compares the two versions of Immensee. In his second chapter, concerned with Am Kamin and Auf dem Staatshof, he offers "Notes on Storm's Narrative Method." The third chapter has as its topic "Death and Survival in the Situation Tragedy: The Beginnings of Storm's Tragic Novellen." In his fourth chapter he discusses "Three Themes in Aquis submersus": "Contrast and Continuity in the Frame," "Death and the Symbol of Painting;" and "The Witch and the Problem of Fate." The fifth chapter seeks to show that Storm's Märchen entitled Hinzelmeier is a "problematic Kunstmärchen" ( $\mathrm{p}$. 130), that "its premises are basically anti-Märchen" (p. 161), and 
that it is "a Biedermeier Erzählung in an unfortunate disguise" (p. 164). These statements might also serve to show how the author invites dissenting opinion, which can lead to a clearer comprehension of Storm's aesthetic purpose. Reviews: (1) Clifford A. Bernd, The German Quarterly, xxxviii (1965), pp. 223-225; (2) Lee B. Jennings, Journal of English and Germanic Philology, lxv (1966), pp. 133-135.

Schumann, Willy, "Theodor Storm," Einführung in die deutsche Literatur, ed. by John Gearey \& Willy Schumann, New York, 1964, pp. 275-295. Thought-provoking discussions of Immensec, Aquis submersus, and Der Schimmelreiter make this essay, in spite of its preceptorial nature, interesting to all critics of these three Novellen.

\section{Studies concerned with Storm's narrative craft as a whole}

Wegner, Herbert, Die Bedeutung der Erinnerung im Erzählwerk Theodor Storms, Diss. (typescript), University of Marburg, 1953. Particularly useful for studies of Im Saal, Immensee, Späte Rosen, Viola tricolor, and Carsten Curator. The author endeavors to explain the role that memory plays in determining the lives of individual characters in these narratives, a role he believes to be exemplary for Storm's fiction as a whole.

Klöckner, Klaus, Die Krise der Tradition in der Novelle Theodor Storms, Diss. (typescript), University of Frankfurt a.M., 1955. Attempts to show that the radical changes that had taken place in social conditions during the nineteenth century are reflected in Storm's tales. Useful for the critic of form because it discusses Storm's descriptions of social life, which, in certain tales, are integral to the narrative form.

Bernd, Clifford A., Die Erinnerungssituation in der Novellistik Theodor Storms, Ein Beitrag zur literarischen Formgeschichte des deutschen Realismus im neunzehnten Jahrhundert, Diss. (typescript), University of Heidelberg, 1958. An earlier study of our own which focuses attention upon the dualism of "remembering" and "remembered" time in all of Storm's prose fiction. 
Herzog, Bert, "Storm und die Vergänglichkeit," Schwcizer Rundschau, lviii (1958), pp. 256-258. Treats an old topic in a new light. Brief, but very illuminating. See the comment at the end of footnote 71 of our study.

Laage, Karl Ernst, "Das Erinnerungsmotiv in Theodor Storms Novellistik," Schriften der Theodor-Storm-Gesellschaft, vii (1958), pp. 17-39. A well-documented essay which demonstrates irrefutably that reminiscence is a dominant motif in Storm's fiction.

Muchitsch, Elisabeth, Der Schicksalsgedanke in den Novellen Theodor Storms, Diss. (typescript), University of Innsbruck, 1958. A discussion of Storm's concept of fate. In many respects a continuation of the ideas set forth by Fritz Lockemann in Gestalt und Wandlungen der deutschen Novelle, München, 1957, pp. 154-181 (see below).

Schumann, Willy, The Technique of Characterization in the late novellas of Theodor Storm, Diss. (typescript), Columbia University, 1959. A very close examination of the major means of characterization in Storm's later tales. The author's copious and subtle observations are extremely valuable for an accurate understanding of the roles of many characters in defining form. One of the chapters has appeared in print, somewhat abridged and in German translation: "Die Umwelt in Theodor Storms Charakterisierungskunst," Schriften der Theodor-Storm-Gesellschaft, xi (1962), pp. 26-38.

Guenther, Paul F., "Storm and Hardy: A Study in Similarity," Kentucky Foreign Language Quarterly, vii (1960), pp. 87-93. By pointing to similarities with Hardy, the author calls attention to a number of salient characteristics of Storm's prose, e.g., its "balladic" character, its antiquarianism, and its wealth of description.

Smeed, J. W., "Theodor Storm and His Reading Public: Some Cases of Editorial Interference and its Effect," Durham University Journal, lii (1960), pp. 125-128. Reveals how imperative it is for the critic of form to consult the manuscripts of the individual tales. 
Theobald. Anne, The Theme of Isolation in the Novellen of Theodor Storm and Ferdinand von Saar, Diss. (typescript), University of London, 1960. An analysis of the characters who experience isolation and the types of solitude in which they live.

Mainland, William F., "Theodor Storm," German Men of Letters, ed. by Alex Natan, London, 1961, pp. 147-168. The writer offers a useful introduction to Storm's craft of fiction, but he also invites challenge when he explains the Rahmenerzählung in the following way: "It is a fictitious device made to overcome the idea of fiction. If the author has taken all the trouble to wrap something up, the reader will think that that something must be genuine" (p. 162). See the comments in footnote 66 of our study.

Jennings, Lee B., "'Shadows from the Void' in Theodor Storm's Novellen," The Germanic Review, xxxvii (1962), pp. 174-189. A very informative, well-documented study concerned with the fantastic element in Storm's prose fiction.

Alt, Arthur Tilo, The Problem of Anxiety in the Works of Storm, Diss. (typescript), University of Texas, 1964. Traces the phenomenon of anxiety, or, more precisely, Erschütterung, in Storm's works. The chapter that addresses itself to "The Problem of Space and Time" is particularly excellent. We single out for special mention several sentences in it that seem to confirm the conclusions of our own study: "The most profoundly shocking experience for the individual in Storm's works is that of transiency. There is not a single Novelle in which evanescence does not assert itself. Storm [we would substitute: the narrator] never ceased to lament the passage of time. No rescue from it seems possible" (p. 200). "Storm uses the memory as a weapon against passing time" (p. 217).

Wedberg, Lloyd Warren, The Theme of Loneliness in Theodor Storm's Novellen, Studies in German Literature No. 1, The Hague, 1964. The author of this study, making no distinction between nonfictional doctrinal statements and the feigned reality of fiction, and frequently citing texts incorrectly, concludes that (1) in Storm's early period the Novellen do not exhibit "a true conquest of loneli- 
ness"; (2) in the transition period some show "a positive conquest," while in others loneliness is merely "actively challenged"; (3) in the last period some show "a complete conquest," others "an active but eventually unsuccessful challenge," and still others "a completely passive submission” (pp. 155-156). Review: Clifford A. Bernd, The German Quarterly, xxxix (1966), pp. 110-112.

\section{Studies concerned with Storm's narrative craft within the framework of nineteenth-century fiction}

Koch, Franz, Idee und Wirklichkeit, ii, Düsseldorf, 1956, pp. 272-311. A modern positivistic discussion of Storm's tales. Useful solely because of the amount of factual information it contains.

Lockemann, Fritz, Gestalt und Wandlungen der deutschen Novelle, München, 1957, pp. 154-181. Attempts to interpret Storm's tales as narratives of "chaos" and "order."

Kunz, Josef, "Geschichte der deutschen Novelle vom 18. Jahrhundert bis auf die Gegenwart," Deutsche Philologie im Aufriss, ii, 2nd ed., Berlin, 1960, pp. 1873-1877. A survey of the main "ideas" in Storm's prose fiction.

Martini, Fritz, Deutsche Literatur im bürgerlichen Realismus, 18481898, 2nd ed., Stuttgart, 1964, pp. 630-664. Traces the development of Storm's narrative prose. Particularly worth-while reading are the comments on Der Schimmelreiter.

\section{Biographies}

Stuckert, Franz, Theodor Storm, Sein Leben und seine Welt (frequently referred to according to title on jacket: Theodor Storm, Seine Welt und sein Werk), Bremen, 1955. Invaluable, because it is the most modern and, except for the French biography of Robert Pitrou, 
the most comprehensive general discussion of Storm's life and works. Stuckert, in diametric contrast to what we have tried to do, attempts to harmonize the dissonances in Storm's tales. Reviews: (1) Peter Goldammer, Neue Deutsche Literatur, iv (1956), Heft 6, pp. 143-146; (2) Friedrich Seebass, Deutsche Rundschau, lxxxii (1956), pp. 205206; (3) Gerhart Baumann, Archiv für das Studium der neueren Sprachen, cxciii (1957), p. 309 ; (4) R. M. Browning, Journal of English and Germanic Philology, lvi (1957), pp. 109-113; (5) Robert Pitrou, Etudes germaniques, xii (1957), pp. 339-342 ; (6) Walter Silz, The Germanic Review, xxxii (1957), pp. 223-225 ; (7) Olaf Klose, Nordelbingen, xxvii (1959), p. 183.

Böttger, Fritz, Theodor Storm in seiner Zeit, Berlin, 1958. A monograph, written from a Marxist point of view, stressing the political and sociological background of Storm's life and works. Interesting because its author endeavors to challenge those interpretations, like our own, which seek to understand Storm's art in terms of form. Review: Peter Goldammer, Neue Deutsche Literatur, vii (1959), Heft 8, pp. 142-146.

Prinzivalli, Lydia, Theodor Storm, Palermo, 1958. A major Italian biography, written from a more Christian viewpoint than perhaps any other study of Storm. Review: A. Cozzi, Annali, Sezione Germanica, ii (1959), pp. 352-355. See the comment at the end of footnote 71 of our study.

\section{Miscellaneous critical studies}

Sievers, Harry, Storms Stellung zu Toa und Unsterblichkeit im Rahmen seiner Lebensanschauung, Diss. (typescript), University of Göttingen, 1953, and, condensed from the preceding, "Storms Gedanken über Unsterblichkeit und Tod in ihrem inneren Zusammenhang," Schriften der Theodor-Storm-Gesellschaft, v (1956), pp. 18-42. Studies of a pronounced positivistic nature concerned with Storm's idea of immortality. See the comment at the end of footnote 71 of our study. 
Peters, Friedrich Ernst, "Rosengeruch des Unwiederbringlichen," Schriften der Theodor-Storm-Gesellschaft, iii (1954), pp. 9-14. An appreciative essay by a contemporary poet.

Lehmann, Wilhelm, "Theodor Storms Gegenwart," Jahrbuch der Heimatgemeinschaft des Kreises Eckernförde, xiii (1955), pp. 17-22; "Die Gegenwart Theodor Storms," Dichtung als Dasein, Hamburg, 1956, pp. 62-67 ; “Theodor Storms Gegenwärtigkeit,” Kunst in Schleswig-Holstein, vii (1957), pp. 79-89. Three different attempts by a modern poet to understand Storm's prose and poetry as products of the nineteenth century, but with artistic appeal to readers in our time.

Goldammer, Peter, "Theodor Storm und die deutsche Literaturgeschichtsschreibung," Aufbau (Berlin), xii (1956), pp. 963-972. Traces the development of Storm criticism. See his other article listed under Critical surveys.

Jenssen, Christian, "Theodor Storm und die Gegenwart," Schriften der Theodor-Storm-Gesellschaft, v (1956), pp. 9-17. Discusses Storm's works with regard to his reading public in the twentieth century.

Colledan, Laura, Theodor Storm Critico, Diss. (typescript), University of Genoa, 1957. The most extensive study that has been written on the subject of Storm's own criticism of the Novelle, lyric poetry, and the literary productions of his contemporaries.

Reuter, Hans-Heinrich, "Das Werk Theodor Storms," Aufbau (Berlin), xiii (1957), pp. 518-526. A detailed, critical review of Peter Goldammer's edition of Theodor Storm: Sämtliche Werke, Berlin, 1956 , commenting rather extensively on Storm's concept of realism.

Fricke, Hermann (ed.), "Erinnerungen an Theodor Storm von Theodor Fontane, Ein nicht vollendeter Nekrolog," Jahrbuch für brandenburgische Landesgeschichte, ix (1958), pp. 26-37. These unpublished notes of Fontane for an essay about Storm he had planned to write, but never completed, offer most interesting reading. There are numerous comments on many of Storm's works. 
Jenssen, Christian, "Theodor Storm im Blickfeld der Literatur des 20. Jahrhunderts," Schriften der Theodor-Storm-Gesellschaft, vii (1958), pp. 9-16. An essay concerned with the influence Storm's writings have had on poets and novelists in the twentieth century.

Fisenne, Otto von, "Theodor Storm als Jurist," Schriften der Theodor-Storm-Gesellschaft, viii (1959), pp. 9-47, and, in expanded form, Theodor Storm als Jurist, Diss. (typescript), University of Hamburg, 1960. A detailed study of Storm's legal carcer, making use of many unpublished and hitherto unknown documents that the author found in the archives of various courts.

De Cort, J., "Een marxistisch oordeel over Theodor Storm," Revuc des langues vivantes, xxvi (1960), pp. 375-381. Criticism of Georg Lukács' references to Storm in Deutsche Realisten des 19. Jahrhunderts, Berlin, 1952.

Boll, Karl Friedrich, "Theodor Storm, Ein Kind seiner Zeit," Schriften der Theodor-Storm-Gesellschaft, x (1961), pp. 9-31. A theologian's endeavor to understand Storm in the light of nineteenth-century philosophy.

Ferré, Margaret V., Religion in the Works of Theodor Storm, Diss. (typescript), University of Pennsylvania, 1962. A study that seeks to determine Storm's religious attitude from references in unreliable editions of his letters, and from alleged mirroring in his fictional characters. The investigation is useful only in reviewing the beliefs of a number of individual characters. See the comment at the end of footnote 71 of our study.

Laage, Karl Ernst, "Theodor Storm und Iwan Turgenjew," Schriften der Theodor-Storm-Gesellschaft, xii (1963), pp. 11-26. An essay that deserves to be mentioned because little is known about its fascinating topic: the impressions that each of these poets had of the other's works. But the essay is also valuable because of its revealing comparison of the prose fiction of these two great contemporaries, both of whom, as we learn, had an acute awareness of the passing of time. 
Schumann, Willy, "Theodor Storm und Thomas Mann: Gemeinsames und Unterschiedliches," Monatshefte, lv (1963), pp. 49-68. The most extensive study of this compelling topic. Reprinted in Schriften der Theodor-Storm-Gescllschaft, xiii (1964), pp. 28-44. See, too, the comments of F. E. Coenen, The German Quarterly, xxxix (1966), p. 113.

Ranft, Gerhard, "Theodor Storm und Friedrich Hebbel," Schriften der Theodor-Storm-Gesellschaft, xiii (1964), pp. 7-27. It is most interesting to read in this essay about Storm's impressions of Hebbel's fiction. Not everyone, however, will readily accept the conclusions that the author has drawn from a comparison of the two poets' works, and the following sentences might serve to show why: Das tragische Grundgefühl ist bei beiden Dichtern das gleiche. Die Tragik des Schimmelreiters ist in der Grundhaltung ganz hebbelisch: nämlich höchste Gewis.scnsentscheidung des cinzelnen (p. 26). See, too, the comments of F. F. Coenen, The German Quarterly, xxxix (1966), pp. 112-113. 


\section{INDEX OF NAMES}

Alt, Arthur Tilo, 132

Andrews, John S., 124

Baesecke, Georg, 98, 99

Baumann, Gerhart, 134

Bennett, E. K., 97

Bernd, Clifford A., 123, 125, 127, 129, 130,133

Bichel, Ulf, IX

Böckmann, Paul, 5, 82, 101

Böhme, Fritz, 85, 98, 100, 102

Böttger, Fritz, 134

Boll, Karl Friedrich, 126, 136

Booth, Wayne C., XI

Bracher, Hans, 88, 91, 92, 96, 97, 102

Braun, Frank X., 127

Brech, Barbara Fuerst, 129

Brinkmann, Richard, 5, 82

Browning, Robert M., 59, 67, 98, 99, 101, 134

Buck, Rudolf, 83, 86, 88, 89, 91, 93

Burchard, Annemarie, 127

Busch, Andreas, 127

Coenen, Frederic E., 42, 94, 137

Colledan, Laura, 135

Cozzi, A., 134

Crane, Ronald S., XI

De Cort, J., 125, 129, 136

de Gelder, J. J., 88
Dieckmann, Liselotte, 128

Doren, Alfred, 85

Düsel, Friedrich, 82

Eichentopf, Hans, 98

Eliot, T. S., 82

Faden, Hannelore, 87

Feise, Ernst, 38, 83, 85, 86, 87, 88, 90 , 93, 94

Ferré, Margaret V., 136

Fisenne, Otto von, 136

Fontane, Theodor, 135

Fränkel, Jonas, XI

Frels, Wilhelm, 120

Fricke, Hermann, 135

Gearey, John, 130

Gebauer, Hannelore, 123, 128

Goethe, Johann Wolfgang von, X, XI, $5,81,89,99,127,128$

Goldammer, Peter, 123, 134, 135

Gottfried von Strassburg, 128

Grillparzer, F., 125, 126

Grimmelshausen, H. J. C. von, 97

Günther, Helmut, IX

Guenther, Paul F., 131

Hamburger, Käthe, 81

Hardy, Thomas, 131

Hebbel, Friedrich, 137 
Hermand, Jost, 128

Herzog, Bert, 131

Heyse, Paul, 57, 85, 93, 119

Hienger, Jörg, IX

Hofacker, Erich, 128

Jennings, Lee B., 130, 132

Jenssen, Christian, 135, 136

Kafka, Franz, 99, 127

Kahler, Erich, 5, 82

Kayser, Wolfgang, 81, 102

Keller, Gottfried, XI, 81, 88, 126, 127

Klamp, Gerhard, 125

Klein, Johannes, 89, 100, 101

Klöckner, Klaus, 130

Klose, Olaf, 134

Koch, Franz, 133

Koch, Margaretha, 120

Köster, Albert, 7, 82, 90, 102, 117, 118

Kuh, Emil, 6, 82, 86

Kunz, Josef, 133

Laage, Karl Ernst, 87, 100, 131, 136

Lämmert, Eberhart, 82

Lange, Victor, X, XI, 5, 81, 82

Lehmann, Wilhelm, 135

Lenhartz, Rolf, 100, 101

Liliencron, Detlev von, 101

Lincke, Werner, IX

Lockemann, Fritz, 100, 131, 133

Loeb, Ernst, IX, 128

Lubbock, Percy, X, XI

Lüpke, Ewald, 119

Lukács, Georg, 136

Luther, Arthur, 85

Mainland, William F., 132

Mann, Thomas, VIII, 4, 125, 137

Martini, Fritz, 5, 77, 82, 103, 124, 133

McCormick, E. Allen, 129

McHaffie, M. A., 124

Merkel-Nipperdey, Margarete, 81

Meyer, C. F., 88
Meyer, Herman, 82, 83, 103

Meyer, Richard M., 90

Mörike, Eduard, 81

Muchitsch, Elisabeth, 131

Müller, Günther, 15, 83

Müller, Thea, 29, 82, 86, 88, 89, 90, 91 , 93, 95

Natan, Alex, 132

Neuse, Werner, IX

Nientimp, Margret, 81

Niess, Albert, 120

Nolte, Fred O., 128

Opitz, Martin, 52, 97, 112, 114

Ovens, Jürgen, 24, 32, 89, 92

Overbeck, Friedrich, 50, 112

Peters, Friedrich Ernst, 135

Petersen, Wilhelm, 57, 97

Pietsch, Ludwig, 85

Pitrou, Robert, 84, 85, 88, 90, 92, 93, $94,99,100,101,102,118,133,134$

Plotke, Georg J., 85, 119

Preisendanz, Wolfgang, XI

Prinzivalli, Lydia, 134

Raabe, Wilhelm, 83

Ranft, Gerhard, 137

Raphael, 50, 112

Reuter, Hans-Heinrich, 135

Richter, Werner, 100

Ritchie, J. M., 124

Rockenbach, Therese, 86, 88, 91, 92, 94, 97

Rowley, B. A., 81

Rückert, Friedrich, 70, 101

Ruisdael, Salomon van, 14

Saar, Ferdinand von, 99, 132

Sander, Volkmar, 81

Schmidt, Erich, 82, 100, 102

Schmidt, Harry, 89

Schopenhauer, Arthur, 125

Schütze, Paul, 72, 90, 102 
INDEX OF NAMES

Schumann, Willy, IX, 90, 130, 131, 137

Schunicht, Manfred, 82

Seebass, Friedrich, 134

Seidler, Herbert, 90

Sievers, Harry, 134

Silz, Walter, 90, 127, 134

Simons, L., IX

Smeed, J. W., 103, 131

Stanzel, Franz, 81

Steege, Victor, 126

Stephan, Dieter, 81

Stinchcombe, J., 126

Storm, Gertrud, 90, 97, 119

Storm, Karl, 11

Stuckert, Franz, 82, 88, 95, 98, 99, 100, $101,102,117,118,120,133,134$
Tempeltey, Ed., 77, 103

Theobald, Anne, 99, 132

Thietz, Rudolf, 102

Turgenev, Ivan, 82, 85, 120, 136

Ubben, John H., 128

Ulshöfer, Robert, 124

van der Helst, Bartholomeus, 24, 88, 89

Vlasimsky, J., 90

Waidson, H. M., 97

Wedberg, Lloyd Warren, 132

Wegner, Herbert, 130

Wiese, Benno von, 99, 127

Wilder, Thornton, 82

Wittmann, Lothar, 126, 127

Wooley, E. O., 28, 90, 123, 124 



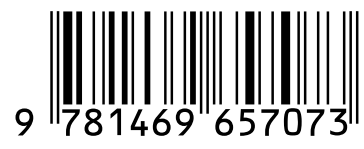

